\title{
Um Protocolo para Rastreamento de Mensagens em Sistemas com Checkpointing Assíncrono
}

\section{Sergio Ricardo da Conceição}

Dissertação apresentada ao Instituto de Matemática e Estatística da Universidade de São Paulo para Obtenção do grau de Mestre em Ciência da Computação

Orientador: Prof. Dr. Markus Endler - IME - USP

- São Paulo, 26 de Outubro de 1997 - 


\title{
Um Protocolo para Rastreamento de Mensagens em Sistemas com Checkpointing Assíncrono
}

\author{
Este exemplar corresponde à redação final \\ da dissertação devidamente corrigida e \\ defendida por Sergio Ricardo da Conceição \\ e aprovada pela comissão julgadora.
}

São Paulo, 26 de Outubro de 1997.

\section{Banca examinadora :}

- Prof. Dr. Markus Endler (orientador) - IME-USP

- Profa. Dra. Dilma Menezes da Silva - IME-USP

- Profa. Dra. Noemi de La Rocque Rodriguez - PUC-RJ

Durante a elaboração deste trabalho o autor recebeu apoio financeiro do CNPQ. 
A meus familiares e amigos, fonte de imensa alegria, incentivo e paciência. 
Agradeço a todos os professores do departamento de ciência da computação do IME pelo modo magnífico com que transmitem seu conhecimento e guiam os alunos perante a difícil caminhada rumo ao imenso universo da sabedoria.

Acredito que entre todas as lembranças, a mais valiosa é a capacidade de pesquisa desenvolvida ao longo destes anos de IME pois, frente aos obstáculos impostos por um ensino de altíssima qualidade, era nosso dever pesquisar a melhor forma de solucioná-los.

$\mathrm{E}$ acredito que assim deve ser em nossa longa jornada neste mundo: devemos sempre procurar o melhor para nós, nossas famílias e nossos amigos. 


\title{
Resumo
}

Neste trabalho especificamos o método de checkpointing para programas distribuídos no contexto do projeto Sampa. Por se tratar de um método de checkpointing assíncrono e orientado ao programa da aplicação, a participação do programador na definição do estado relevante e na inclusão de checkpoints no código fonte do programa de aplicação é fundamental. Para permitir o completo restabelecimento de estado da nova instância de um processo faltoso, o método utiliza um mecanismo de rastreamento de mensagens entre processos. Nosso protótipo implementa o método de rastreamento de mensagens baseado no remetente proposto originalmente por Johnson e Zwaenepoel, adaptado à arquitetura do sistema Sampa. A validação do método foi feita através de diversos exemplos de execução e vários padrões de comunicação tais como multiplexador FIFO, anel bidirecional e servidor concorrente FIFO.

\begin{abstract}
In this work we specified the checkpointing method for distributed programs in the context of the Sampa project. Since the method performs assyncronous checkpointing and is applicationoriented, the participation of the programmer in the definition of the relevant state and the checkpoints within the program source code is fundamental. To allow a correct re-establishment of the state of a new instance of a faulty process, the method uses a logging mechanism for messages sent among processes. Our prototype implements the sender-based message logging originally proposed by Johnson and Zwaenepoel, and adapted to the architecture of the Sampa system. The correctness of the method was verified through the prototype execution of several examples and communication patterns such as FIFO multiplex server, two-way token ring and concurrent FIFO server.
\end{abstract}




\section{Sumário}

1 Introdução 1

1.1 Prevenção e tolerância a falha . . . . . . . . . . . . . . . . . . 2

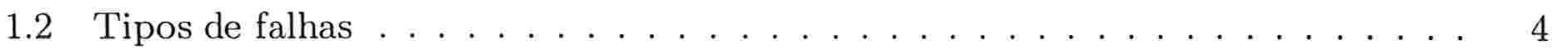

1.3 Aplicações do checkpointing . . . . . . . . . . . . . . . . . . 4

1.3.1 Retomada de execução . . . . . . . . . . . . . . . . . 4

1.3.2 Migração de processos . . . . . . . . . . . . . . 5

1.3.3 Sincronização de estado de execução . . . . . . . . . . . . . . 5

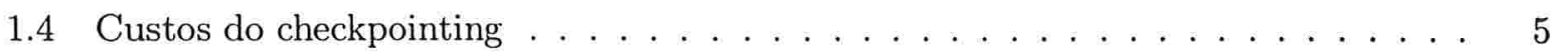

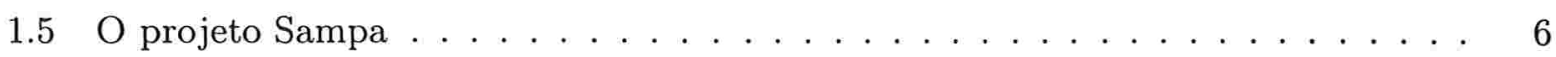

1.5.1 Tolerância a falha no Sampa . . . . . . . . . . . . . 7

1.5.2 Contribuição deste trabalho ao projeto Sampa $\ldots \ldots \ldots$. . . . 8

1.6 Conceitos básicos . . . . . . . . . . . . . . . . . . . . 9

2 Métodos de restabelecimento de estado $\quad 13$

2.1 Motivação . . . . . . . . . . . . . . . . . . . . 13

2.2 Classificação geral . . . . . . . . . . . . . . . . . . . . . 14

2.3 Checkpointing coordenado ou distribuído . . . . . . . . . . . . . 16

2.3.1 Protocolos de sincronização . . . . . . . . . . . . . . 17

2.3.2 Restabelecimento de estado . . . . . . . . . . . . . . . . . . 18

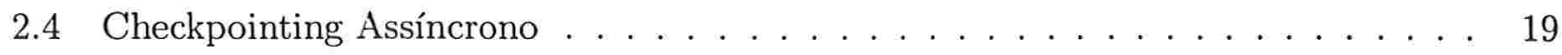

2.4.1 Obtenção dos checkpoints locais . . . . . . . . . . . . . . . . 19

2.4 .2 Rastreamento de mensagens . . . . . . . . . . . . . . . . . . . . 19

2.4 .3 Restabelecimento de estado . . . . . . . . . . . . . . . . . . 20 
2.5 Otimizações . . . . . . . . . . . . . . . . . . . 20

2.5 .1 O volume do estado relevante . . . . . . . . . . . . 20

2.5.2 Frequência do checkpointing . . . . . . . . . . . . . . . . 21

2.6 Implementações de checkpointing . . . . . . . . . . . . . . . . . . . 22

3 Métodos de rastreamento de mensagens $\quad 25$

3.1 Métodos otimistas e pessimistas . . . . . . . . . . . . . 25

3.2 Rastreamento baseado no remetente . . . . . . . . . . . . . 26

3.2.1 Informações e estruturas de dados . . . . . . . . . . . . 26

3.2 .2 O protocolo de comunicação . . . . . . . . . . . . 27

3.2 .3 Restabelecimento de estado . . . . . . . . . . . . . . . . . 28

3.2 .4 Comentários adicionais . . . . . . . . . . . . . . . . 28

3.2 .5 Características do método . . . . . . . . . . . . . . 30

3.3 Rastreamento baseado no destinatário . . . . . . . . . . . . . . . 30

4 Checkpointing a ser adotado no Sampa 33

4.1 O método de checkpointing . . . . . . . . . . . . . . . . 33

4.1 .1 Características do método . . . . . . . . . . . . . . . . . . 34

4.1 .2 Restrições do método . . . . . . . . . . . . . . . . . . 35

4.1 .3 A técnica de rastreamento de mensagens . . . . . . . . . . . . . . 35

4.2 Interação entre as componentes durante o processamento normal . . . . . . . . . 36

4.3 Detecção de falhas e restabelecimento de estado . . . . . . . . . . . . . . . . 37

4.4 Análise do método de checkpointing . . . . . . . . . . . . . . . . . . . . 39

5 O protótipo $\quad 41$

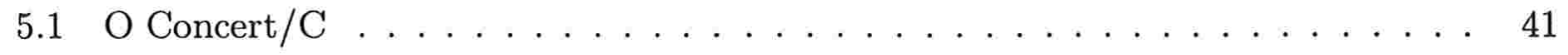

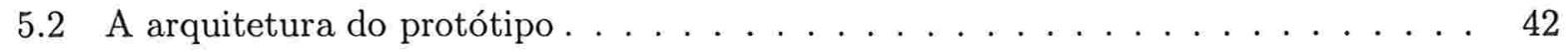

5.3 Interface e interação entre as componentes . . . . . . . . . . . . . . . . . . 44

5.3 .1 Interface das componentes . . . . . . . . . . . . . . . . . 44

5.3 .2 Interação entre componentes no processamento normal . . . . . . . . . 46

5.3.3 Interação entre componentes no processamento pós falha . . . . . . . . . 47

5.4 Configuração e uso do protótipo . . . . . . . . . . . . . . . . . 50 


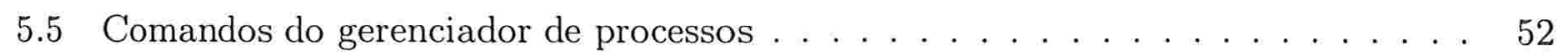

5.6 Informações e estruturas de dados . . . . . . . . . . . . . . . . 57

5.6 .1 Supervisor do sistema . . . . . . . . . . . . . . 57

5.6 .2 Checkpoint daemons . . . . . . . . . . . . . . . . 58

5.6 .3 Processos de aplicação . . . . . . . . . . . . . . . . . 58

5.7 Possíveis extensões . . . . . . . . . . . . . . . . . . . . . . . . 59

6 Exemplos de utilização do protótipo $\quad 61$

6.1 Avaliando propriedades básicas . . . . . . . . . . . . . . . . . . 61

6.1 .1 Processamento normal do sistema . . . . . . . . . . . . . . . 63

6.1 .2 Simulando falha em um processo de aplicação . . . . . . . . . . . . . 65

6.1.3 Restabelecendo o estado da nova instância . . . . . . . . . . . . . . 66

6.1 .4 Continuidade do sistema após o restabelecimento $\ldots \ldots \ldots \ldots$. . . . 70

6.1.5 Gráfico comparativo de tempos . . . . . . . . . . . . . . . . 70

6.1 .6 Consideração final . . . . . . . . . . . . . . . . . . . . . 72

6.2 Processamento com checkpointing intermediário . . . . . . . . . . . . . 72

6.2.1 Restabelecendo o estado da nova instância . . . . . . . . . . . . . . . 73

6.3 Avaliando mensagens parcialmente armazenadas . . . . . . . . . . . . 75

6.3.1 Colocando mensagens no canal de comunicação . . . . . . . . . . . 75

6.3 .2 Restabelecimento de estado da nova instância . . . . . . . . . . . . . . 77

6.4 Custos de desempenho do protótipo . . . . . . . . . . . . . 78

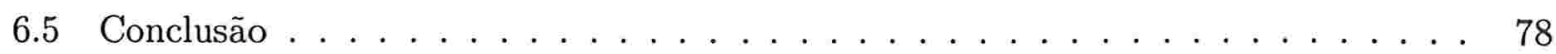

6.5.1 Vantagens e desvantagens do protocolo . . . . . . . . . . 78

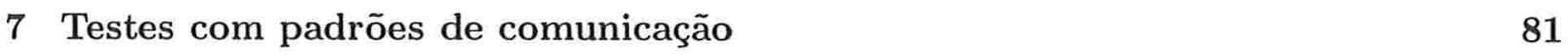

7.1 Mestre-escravo . . . . . . . . . . . . . . . . . . . . 83

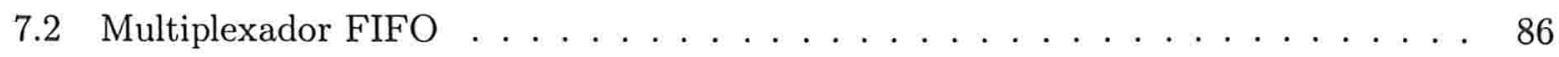

7.3 Servidor Intermediário $\ldots \ldots \ldots \ldots \ldots \ldots$

7.4 Anel unidirecional . . . . . . . . . . . . . . . . . . . . . . 90

7.5 Anel bidirecional . . . . . . . . . . . . . . . . . . . . . 92

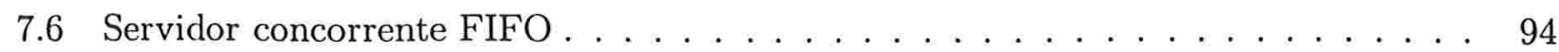


7.7 Conclusão . . . . . . . . . . . . . . . . . . . . . 96

8 Conclusão $\quad 97$ 


\section{Lista de Figuras}

1.1 Camadas de tolerância a falha . . . . . . . . . . . . . . . . 2

1.2 A arquitetura do Sampa . . . . . . . . . . . . . . . . . 7

1.3 A arquitetura do Sampa: novo daemon do sistema . . . . . . . . . . . . 8

1.4 Modelo de um computação distribuída . . . . . . . . . . . . . . . . . . . 10

1.5 Cortes consistente $(\mathrm{C})$ e inconsistente $\left(\mathrm{C}^{\prime}\right) \ldots \ldots \ldots \ldots \ldots \ldots \ldots$

2.1 Efeito dominó . . . . . . . . . . . . . . . . . . . . . . . . . 14

2.2 Determinando linhas de restabelecimento . . . . . . . . . . . . . . 17

2.3 Otimização no restabelecimento de estado $\ldots \ldots \ldots \ldots \ldots \ldots$

3.1 Protocolo de comunicação confiável . . . . . . . . . . . . . . . 27

3.2 Suspensão temporária do envio de mensagens pelo processo receptor . . . . . . . 29

3.3 Processo de remoção das mensagens dos logs dos remetentes . . . . . . . . . . . . 29

3.4 Rastreamento de mensagens baseado no receptor . . . . . . . . . . . . . . . 31

4.1 Código ilustrando o método de checkpointing . . . . . . . . . . . . . . 34

4.2 Interação entre as componentes do ambiente Sampa . . . . . . . . . . . . 36

4.3 Sincronização durante o restabelecimento de execução $\ldots \ldots \ldots$. . . . . . . . 38

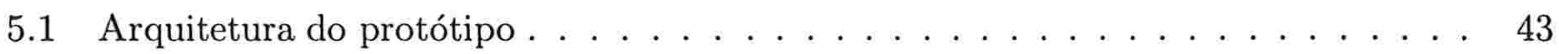

5.2 Interação entre componentes no processamento normal . . . . . . . . . . . 46

5.3 Sincronização durante o restabelecimento de execução . . . . . . . . . . . . . 48

5.4 Configuração do protótipo . . . . . . . . . . . . . . . . 50

5.5 Exemplo ilustrativo dos comandos do gerenciador . . . . . . . . . . . . 52

6.1 Diagrama de eventos . . . . . . . . . . . . . . . . . 62 
6.2 Gráfico comparativo de tempo . . . . . . . . . . . . . . . . . 71

6.3 Diagrama de eventos com checkpointing intermediário $\ldots \ldots \ldots \ldots \ldots$

6.4 Diagrama de eventos com mensagens parcialmente armazenadas . . . . . . . . 76

7.1 Configuração de máquinas para validação do protótipo $\ldots \ldots \ldots$. . . . . . . 82

7.2 Configuração mestre-escravo . . . . . . . . . . . . . . . . . . . 84

7.3 Configuração dos eventos . . . . . . . . . . . . . . . . . . 84

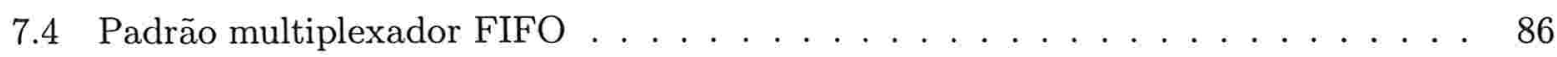

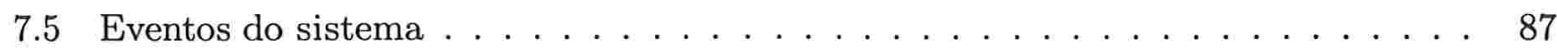

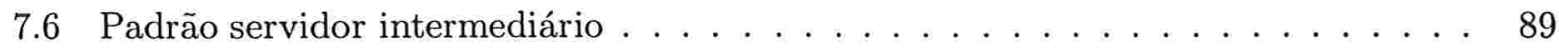

7.7 Ordem dos eventos $\ldots \ldots \ldots \ldots \ldots \ldots \ldots \ldots$

7.8 Padrão anel unidirecional $\ldots \ldots \ldots \ldots \ldots$

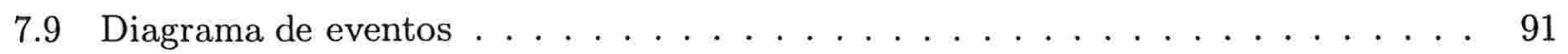

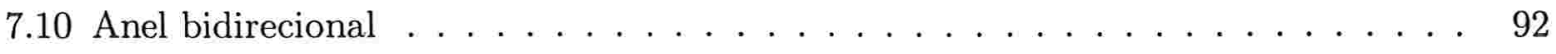

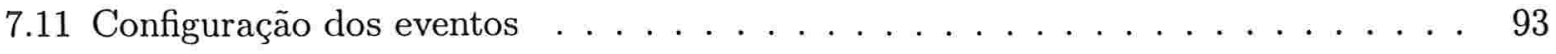

7.12 Padrão Servidor FIFO . . . . . . . . . . . . . . . . . . . . . . . . . . 94

7.13 Configuração dos eventos no padrão servidor FIFO . . . . . . . . . . . . . . . . . 94 


\section{Capítulo 1}

\section{Introdução}

Atualmente o uso de redes de computadores está se tornando mais comum devido a seu alto desempenho computacional. Embora este tipo de ambiente possua uma série de vantagens, apresenta também alguns inconvenientes, tais como, a dificuldade de detectar e lidar com falhas que comumente acontecem. Talvez seja por isso que a capacidade de processamento de uma rede de estações de trabalho seja, frequentemente, muito pouco explorada na prática.

Cada camada de um sistema (por exemplo, o hardware, o sistema operacional e as aplicações) pode apresentar um conjunto distinto de falhas e geralmente uma falha não corrigida em qualquer uma delas se propaga até as camadas seguintes. Ao longo deste trabalho descreveremos os tipos de falhas mais comuns em sistemas distribuídos, estudaremos técnicas de restabelecimento de estado de processos faltosos e implementaremos um mecanismo de rastreamento de mensagens para métodos de checkpointing assíncrono.

De um modo geral, técnicas de restabelecimento de estado baseadas em checkpointing salvam periodicamente informações que caracterizam o estado de execução de um conjunto de processos $P$ durante o período de execução normal (isto é, sem falhas). Na presença de uma falha em qualquer um dos processos pertencentes ao conjunto $P$, uma nova instância do processo faltoso inicia a execução em algum nó disponível da rede a partir do último conjunto de informações salvo, minimizando o desperdício de trabalho já efetuado pela instância faltosa.

Este trabalho é estruturado da seguinte forma: o primeiro capítulo introduz diversos níveis de tolerância a falha e especifica qual tipo de falha é tratado por nossos mecanismos básicos de checkpointing. Em seguida, descrevemos algumas aplicações e analisamos os custos relacionados aos mecanismos de checkpointing. A última seção apresenta algumas definições e conceitos básicos utilizados no restante do texto. No capítulo 2 classificamos os métodos de restabelecimento de estado e descrevemos as principais características de duas metodologias de checkpointing muito conhecidas: o checkpointing coordenado e o assíncrono. No terceiro capítulo estudamos dois métodos de rastreamento de mensagens dando ênfase ao rastreamento de mensagens baseado no remetente que serviu de base para a implementação de um protótipo. O capítulo 4 descreve, em detalhes, a técnica de checkpointing a ser adotada no projeto Sampa. No quinto capítulo apresentamos a arquitetura e as principais características do protótipo, e no sexto capítulo analisamos 
alguns exemplos de execução com o intuito de descrever sua funcionalidade. No capítulo 7 é feita a validação do protótipo através do teste de diversos padrões de comunicação, tais como, clientes interagindo com um servidor FIFO e processos interligados na topologia de anel lógico. No último capítulo concluímos o trabalho descrevendo as experiências adquiridas na implementação do protótipo e mencionamos possíveis futuros trabalhos.

\subsection{Prevenção e tolerância a falha}

Para atingir a meta de tornar os sistemas computacionais mais confiáveis, duas técnicas complementares podem ser seguidas: prevenção de falha e tolerância a falha.

A primeira objetiva a confiabilidade do sistema através de uma fase de especificação e estruturação cuidadosa, seguida de uma extensa bateria de testes antes da implantação do sistema.

No entanto, esta técnica não é suficiente, pois sempre haverá falhas residuais que poderão culminar com a interrupção da execução de um ou mais módulos do sistema. Para tratar destes resíduos e aumentar a integridade, a disponibilidade de recursos e a segurança do sistema, deve-se utilizar técnicas de tolerância a falha que permitam ao sistema continuar a executar corretamente, mesmo na presença de falhas.

De um modo geral, tolerância a falha pode ser idealizada em três níveis: ao nível de máquina, de sistema operacional e ao nível de aplicações, conforme ilustrado na figura 1.1.

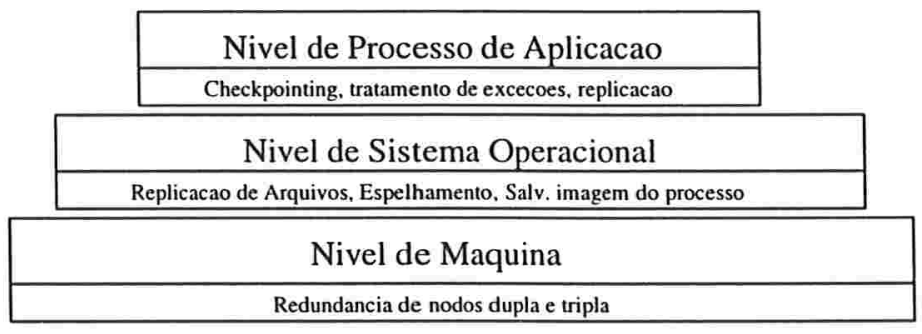

Figura 1.1: Camadas de tolerância a falha

Diversas análises feitas sobre sistemas faltosos sugerem que, em geral, falhas ocorridas a nível de máquina estão se tornando pouco frequentes, em parte, porque seus componentes estão apresentando uma confiabilidade bastante satisfatória e, em outra, devido a utilização de métodos eficientes, tais como, redundância de nodos dupla e tripla [31].

Da mesma forma, métodos de tolerância a falha a nível de sistema operacional são empregados com bastante sucesso. Dentre eles, podemos citar a replicação de sistemas de arquivos [33], espelhamento de disco [4] e checkpointing baseado em transações [28].

Existem implementações de ferramentas de tolerância a falha para processos de aplicação a nível de sistema operacional, como o MVS da IBM [36]. No entanto, Saltzer et.al. [34] afirmam que tais métodos são necessariamente incompletos, porque não é possível restabelecer totalmente a execução de uma aplicação sem o conhecimento completo de diversas características específicas 
da mesma. Além disso, Huang e Kintala [17] mostram a ineficiência obtida através deste tipo de abordagem dando um exemplo de replicação de arquivos em discos espelhados.

Os métodos e técnicas acima descritos previnem, detectam e corrigem com sucesso falhas ocorridas apenas em seus respectivos níveis. Isto sugere que falhas ocorridas ao nível de aplicação devam ser detectadas e corrigidas por novas técnicas, tais como, métodos de checkpointing, tratamento de exceções e replicação ativa de processos. É neste contexto que o presente trabalho se concentrará.

De acordo com Huang e Kintala [17], tolerância a falha ao nível de aplicação pode ser implementada em cinco níveis.

Nível 0. Não há tolerância a falha a nível de aplicação.

Quando uma aplicação apresenta uma falha, ela deve ser restaurada manualmente a partir do estado inicial.

Nível 1. Deteç̧ão automática e restabelecimento de execução.

Quando uma aplicação apresenta uma falha, esta é automaticamente detectada e a aplicação é restaurada a partir do estado inicial.

Nível 2. Nivel 1 mais checkpointing periódico, rastreamento de mensagens e restabelecimento a partir do último estado local salvo.

Neste nível, o estado local da aplicação é periodicamente salvo em disco durante o período de execução normal. Quando uma falha é detectada, a execução da aplicação é retomada a partir do último estado local salvo e as mensagens trocadas entre os processos são reprocessadas para reconstruir completamente o estado no qual a aplicação se encontrava no momento anterior à falha.

Nível 3. Nível 2 mais checkpointing de arquivos.

Os arquivos manipulados pela aplicação são replicados em nós (de backup) da rede e são mantidos consistentes em relação aos arquivos presentes no nó primário durante a execução da aplicação. No caso de uma falha, a nova instância da aplicação retoma a execução no nó de backup e os arquivos replicados reconstruirão, da melhor forma possível, o estado da aplicação.

Nível 4. Execução contínua sem interrupção.

Este nível garante a melhor tolerância a falha teoricamente possível. Normalmente pode ser atingido replicando-se processos em máquinas distintas.

Nosso protótipo implementa o mecanismo de rastreamento de mensagens baseado no remetente descrito em [21] com algumas otimizações exigidas pelo projeto Sampa. O nível de tolerância a falha obtido por processos que utilizam nosso método de checkpointing é o nível 2. 


\subsection{Tipos de falhas}

Há uma grande variedade de tipos de falhas frequentemente encontrados na literatura de sistemas distribuídos. Vejamos, brevemente, algumas delas conforme definido em [32].

Diz-se que um processo de aplicação sofre uma falha de parada (fail-stop) quando ocorre uma interrupção permanente em sua execução sendo, entretanto, possível detectar a indisponibilidade do processo.

Uma falha do tipo crash é semelhante à falha de parada. No entanto, a indisponibilidade do processo pode ou não ser detectável.

Os próximos tipos de falhas são relativos às mensagens trocadas entre aplicações distribuídas.

Falhas do tipo crash + link ocorrem quando um processo sofre uma falha do tipo crash adicionado do fato de que algumas mensagens podem ser perdidas, mas não há demora, duplicação nem corrupção de mensagens.

A falha omissão de recepção ocorre quando um processo deixa de receber do subsistema de comunicação algumas mensagens enviadas através de um meio de comunicação sem falhas. Falhas do tipo omissão de envio ocorrem quando um processo deixa de enviar mensagens por um meio de comunicação sem falhas. A falha denominada omissão genérica é caracterizada por uma falha de omissão de recepção e/ou omissão de envio de mensagens.

O mecanismo de rastreamento de mensagens implementado em nosso protótipo trata especificamente de falhas do tipo fail-stop. Portanto, no restante do texto, quando mencionarmos o termo falha deve-se entender que estamos nos referindo a este tipo de falha em particular.

A fim de simplificar a explanação, fixaremos a seguinte notação: se um processo genérico $p$ sofre uma falha do tipo fail-stop, $p$ será chamado de processo faltoso ou morto e o novo processo, cujo estado local será restabelecido por nossos mecanismos, será denominado $p$ ', que chamaremos de nova instância do processo faltoso $p$ ou simplesmente nova instância.

\subsection{Aplicações do checkpointing}

Há várias formas de obter o checkpointing de um conjunto de processos, e cada uma delas mais adequada a um certo tipo de aplicação. A seguir descrevemos algumas aplicações desta técnica, independentemente da variante de checkpointing utilizada.

\subsubsection{Retomada de execução}

A retomada de execução de processos faltosos é uma das principais aplicações do checkpointing. Uma vez detectado falha em um processo, basta executar uma nova instância em alguma máquina disponível a partir do último estado local salvo. Esta aplicação é especialmente 
importante em processos cujo comportamento depende de estados prévios, pois garante maior disponibilidade.

Um caso particular da retomada de execução é a transposição de longas rotinas de inicialização. Certos tipos de aplicações lêem um conjunto de dados de entrada $A$ e realizam longas rotinas de inicialização para obter uma base de dados $B$ a partir de onde ocorrerá o processamento que culminará com a exibição do resultado $R$. Em certos casos, a mesma base de dados $B$ pode ser obtida a partir de um conjunto distinto de dados de entrada $A$ '. Portanto, se efetuarmos um checkpointing do estado da aplicação logo após obtermos a base $B$, uma vez identificado um elemento $a \in A$ ', basta restabelecer o estado da aplicação, processar a base $B$ e exibir o resultado final, minimizando o tempo necessário despendido pela aplicação para calcular a base inicial de processamento.

\subsubsection{Migração de processos}

A técnica de migração consiste em transferir processos de uma máquina para outra da seguinte forma: inicialmente, salva-se o estado local do processo a ser migrado em disco e sua execução é interrompida; em seguida, uma nova instância é executada em outra máquina a partir do estado local salvo, restabelecendo a execução do ponto em que foi interrompido.

Há vários trabalhos relacionados a otimizações de técnicas de migração de processos, e dentre estes, destacamos $[15,40,42]$.

A migração de processos pode ser usada para balancear a carga em um conjunto de máquinas e transferir processos de execução demorada para máquinas menos utilizadas.

\subsubsection{Sincronização de estado de execução}

O checkpointing também é frequentemente utilizado para sincronizar o estado de execução entre processos replicados. É empregado, em particular, quando um novo processo deve ser incluído em um grupo de processos replicados, já que tipicamente o novo processo precisa ser iniciado com o estado dos demais membros do grupo.

Em vista dos objetivos do projeto Sampa, no qual esta proposta se insere, estamos particularmente interessados no caso de checkpointing para a retomada de processos faltosos, migração de processos e a sincronização de estado de execução.

\subsection{Custos do checkpointing}

A principal característica de qualquer mecanismo de tolerância a falha é a existência de custos adicionais. Dentre os custos relativos às técnicas de tolerância a falha baseadas em checkpointing, destacamos: 
Tempo e espaço. O gasto adicional de espaço advém do fato de que a operação de checkpointing salva em disco os dados relativos ao estado local dos processos. Obviamente, esta operação aumenta o tempo total de execução da aplicação, já que tipicamente esta permanece temporariamente sem apresentar progressos durante a transferência dos dados para o disco, além do fato de que o tempo de acesso a disco é lento.

Instrumentação. Técnicas de checkpointing exigem a instrumentação do programa da aplicação com chamadas a procedimentos de bibliotecas que salvam e carregam o estado local em disco. Para tanto, é necessário fazer novas codificações e compilações do programa da aplicação, o que representa um custo adicional em termos de pre-execução.

Sincronização. Como o estado de uma aplicação distribuída é composta do estado de seus processos, algumas técnicas de checkpointing necessitam de mecanismos que permitam a sincronização durante o armazenamento ou recuperação dos mesmos. De um modo geral, tal sincronização requer complexos protocolos de comunicação que degradam o desempenho da aplicação.

Conforme detalharemos ao longo do texto, o método de rastreamento implementado minimiza sensivelmente o volume do estado local de cada processo salvo em disco. Entretanto, há um gasto relativo ao rastreamento de mensagens que é caracterizado pela frequência com que o checkpointing é efetuado.

O método de checkpointing assíncrono proposto no projeto Sampa não exige sincronização de processos durante o armazenamento de estados, embora a retomada de execução requeira uma coordenação de passos entre as componentes do sistema para restabelecer completamente o estado local da nova instância.

Não é objetivo deste trabalho dar apoio à instrumentação das aplicações. O projeto Sampa prevê diretivas de pre-processamento que permitirão ao programador anotar de forma simples as variáveis representantes do estado local da aplicação, bem como, os trechos do programa da aplicação onde deverão ser gerados os procedimentos para armazenar e recuperar o estado local do processo.

\subsection{O projeto Sampa}

O Sampa (Sistema para o Gerenciamento de Disponibilidade de Aplicações Distribuídas Baseadas em Processos) [12] foi projetado para gerenciar tolerância a falha de programas e serviços baseados no ambiente DCE (Ambiente de Computação Distribuída) [35].

A arquitetura do sistema Sampa foi idealizada para que o gerenciamento de disponibilidade fosse feito em dois níveis. Em um nível mais baixo, agentes presentes em cada nó da rede executam todas as tarefas de gerenciamento local de processos (criação, remoção, detecção de falha e posterior correção de processos faltosos), assim como o monitoramento dos mesmos, incluindo filtragem, análise de dados, etc. Em um nível mais alto, um supervisor toma decisões globais de gerenciamento para cada serviço distribuído (ou processo de aplicação), de acordo com suas 
especificações de disponibilidade e dados monitorados recebidos dos agentes. Tais especificações incluem o controle global do monitoramento e diretivas de reconfiguração que são interpretadas pelo supervisor e são repassadas aos agentes correspondentes como comandos básicos. Além disso, o supervisor mantém uma base de dados contendo a imagem da configuração corrente de todos os processos, possibilitando consultas sobre localizações e conexões entre diversos processos. O supervisor também constitui a interface com o usuário, possibilitando uma configuração "on-line" de processos e serviços distribuídos.

A infra-estrutura para gerenciamento no Sampa consiste de um conjunto de serviços básicos e um conjunto de agentes disponíveis em cada nó do sistema, conforme ilustrado na figura 1.2. Os agentes são responsáveis pelo monitoramento de vários recursos da máquina, do sistema operacional e da biblioteca de execução do DCE em seus respectivos nós (por exemplo, utilização da CPU e memória, taxa de utilização de RPC), análise dos dados e posterior envio de notificações ou requisições de serviços ao supervisor. Portanto, os agentes têm total controle sobre todos os processos e serviços do Sampa executando em seus respectivos nós.

Conforme os requisitos do Sampa com relação à tolerância a falha, os agentes também são encarregados de monitorar outros agentes e enviar notificações sobre qualquer tipo de falha (o que inclui falha em processos de aplicação, queda de nós do sistema, partição da rede) aos outros agentes e ao supervisor.

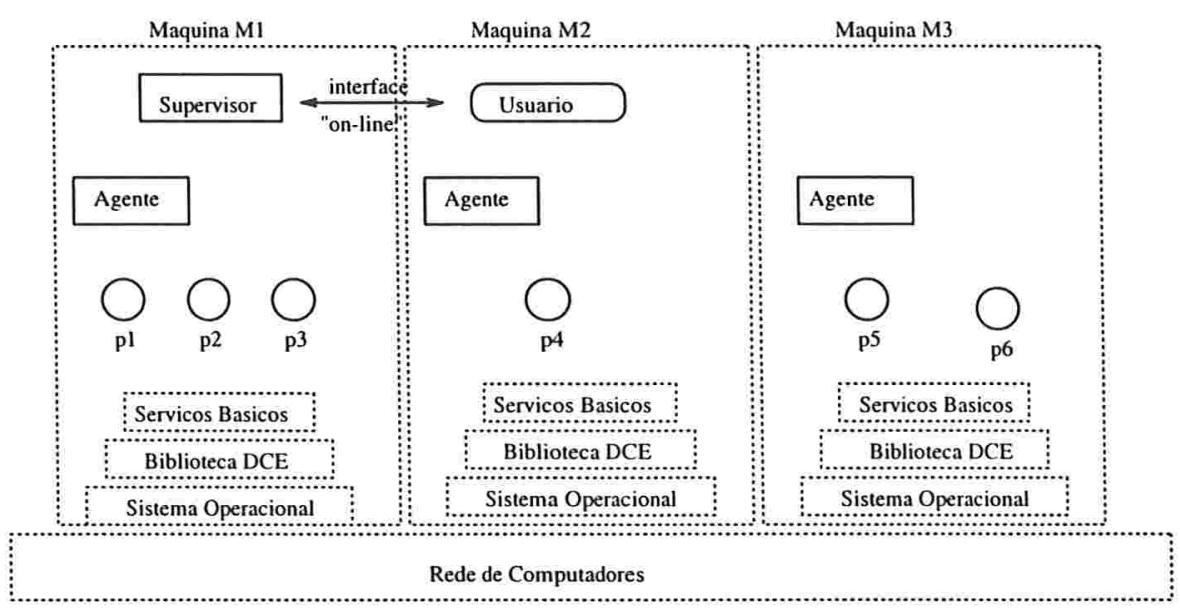

Figura 1.2: A arquitetura do Sampa

\subsubsection{Tolerância a falha no Sampa}

Para implementar tolerância a falha a nível de aplicação no Sampa, um conjunto de serviços básicos incluindo pertinência a grupo, comunicação de grupo, monitoramento de aplicações e mecanismos básicos para checkpointing no nível 2 (conforme classificação estabelecida na seção 1.1) estão sendo desenvolvidos em forma de bibliotecas de execução e processos do sistema (daemons e clerks) que requisitarão chamadas do sistema operacional e aos serviços do DCE. 
Através do serviço de monitoramento será possível detectar falhas ou sobrecarga em processos de aplicação. O serviço de pertinência a grupo, por sua vez, permitirá um monitoramento e controle de disponibilidade dos próprios serviços do sistema Sampa, e a comunicação de grupo confiável fornecerá requisitos para implementar serviços tolerantes a falha por meio de processos replicados.

O suporte para checkpointing consistirá de duas partes: as rotinas de leitura e gravação do estado local dos processos, e a sincronização de ações necessárias para restabelecer completamente o estado da nova instância. A primeira parte foge aos nossos objetivos, e por isso não será estudada neste trabalho. A segunda é a essência deste estudo e será tratada em detalhes ao longo do texto.

Com o objetivo de minimizar a instrumentação inerente às técnicas de checkpointing, o projeto prevê a implementação de um pre-processador para programas de aplicações escritos em linguagem C. Uma vez definida e anotadas as variáveis e estruturas de dados relevantes a cada programa de aplicação, o pre-processador gera procedimentos para salvar e recuperar o valor destas variáveis e estruturas de dados em um arquivo específico.

\subsubsection{Contribuição deste trabalho ao projeto Sampa}

A principal contribuição deste trabalho é especificar em detalhes o método de checkpointing a ser adotado no Sampa, bem como, a sincronização de ações e interação entre as componentes do sistema durante o restabelecimento de estado da nova instância de um processo faltoso. Para complementar esta parte teórica, foi desenvolvido um protótipo que contém todas estas especificações, possibilitando incorporá-lo ao Sampa com pequenas adaptações.

Durante a fase de especificação dos mecanismos de checkpointing, foi necessário definir uma nova componente do sistema em cada máquina, denominada checkpoint daemon, ilustrada na figura 1.3.

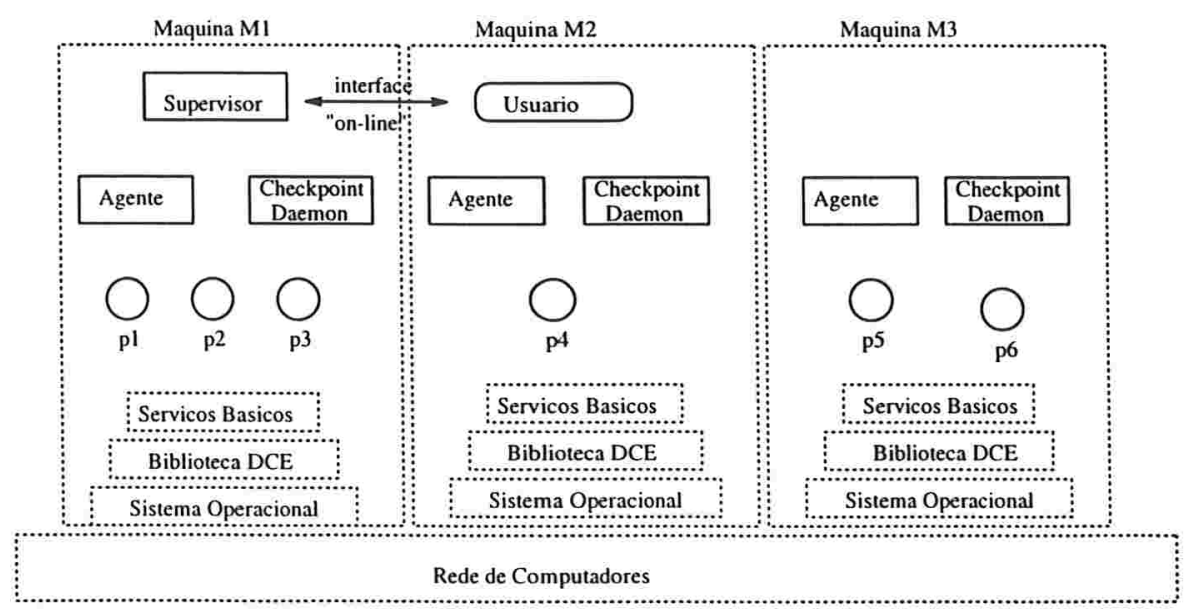

Figura 1.3: A arquitetura do Sampa: novo daemon do sistema 
Por hora, descrevemos sucintamente as principais atribuições deste conjunto de daemons, deixando os detalhes para os capítulos 4 e 5 , onde estudaremos minuciosamente o método de checkpointing adotado em Sampa e as características e funcionalidades do protótipo implementado, respectivamente. São atribuições dos checkpoint daemons: rastrear o conjunto de mensagens trocadas entre as aplicações; interagir com os agentes e com o supervisor para obter informações sobre o processo faltoso $p$ e sua nova instância $p$ '; e sincronizar ações com as demais componentes do Sampa para iniciar o reprocessamento de mensagens à nova instância em retomada de execução.

\subsection{Conceitos básicos}

A seguir apresentamos alguns conceitos básicos que auxiliarão a compreensão da presente proposta. Maiores detalhes podem ser encontrados em [32].

Uma aplicação distribuída consiste de um conjunto de processos de aplicação que interagem por meio de mensagens. Utilizaremos também o sinônimo processo para nos referir às componentes de uma aplicação distribuída. Um processo é faltoso quando sofre uma falha ao longo de sua execução. Empregaremos, frequentemente, os termos instância faltosa ou instância morta para nos referir a um processo faltoso.

Portas de comunicação são endereços associados a processos, destinados a receber mensagens do ambiente de execução. Um binding é uma referência a uma porta de comunicação. Um canal de comunicação unidirecional do processo $p$ para $q$ é estabelecido através do conhecimento por $p$ do binding da porta de comunicação do processo $q$.

Uma computação distribuída consiste de um conjunto de processos interligados por canais de comunicação que executam em um conjunto de máquinas autônomas que não compartilham memória.

Um evento em uma computação distribuída é uma transição espontânea de estado, uma recepção ou um envio de uma mensagem em um processo.

A figura 1.4 ilustra o conceito de evento através da modelagem de um processamento distribuído no qual cada eixo horizontal representa a execução de um processo ao longo do tempo.

Um evento é representado por $e_{i}$ no respectivo eixo de execução do processo. Por exemplo, os eventos $e_{1}$ e $e_{2}$ representam eventos de envio e recepção de mensagens ocorridos no processo $p$, respectivamente. As flechas representam mensagens entre os processos. Neste exemplo, a mensagem $m$ foi enviada pelo processo $p$ através do evento $e_{1}$ e foi recebida por $q$ através do evento $e_{2}^{\prime}$.

Ao longo do texto representaremos apenas as trocas de mensagens efetuadas entre os processos, omitindo a representação dos demais eventos por serem de pouca relevância para a compreensão deste trabalho.

Diz-se que um evento $e_{i}$ precede casualmente um evento $e_{j}$ se ocorrer uma das seguintes condições: 


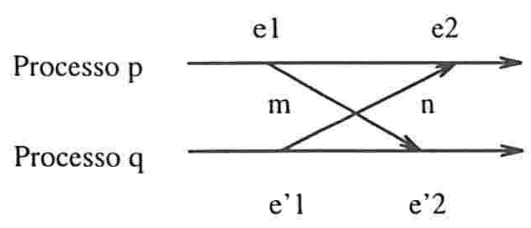

Figura 1.4: Modelo de um computação distribuída

1. $e_{i}$ e $e_{j}$ são eventos de um mesmo processo e $e_{i}$ ocorre antes de $e_{j}$.

2. $e_{i}$ é um evento de envio de uma mensagem $m$ em um processo e $e_{j}$ é o correspondente recebimento de $m$ em outro processo.

A notação $e_{i} \rightarrow e_{j}$ indica que $e_{i}$ precede casualmente $e_{j}$.

Por exemplo, na ilustração 1.4 , o evento $e_{1}$ precede casualmente o evento $e_{2}$ pela condição 1 . Pela segunda condição, o evento $e_{1}$ precede casualmente o evento $e_{2}^{\prime}$

Diz-se que $e_{i}$ e $e_{j}$ são eventos casualmente relacionados se $e_{i} \rightarrow e_{j}$ ou $e_{j} \rightarrow e_{i}$. Caso contrário, diz-se que $e_{i}$ e $e_{j}$ são eventos concorrentes.

A história local de um processo é formada pela sequência de eventos que ocorrem durante sua execução. A história global de um sistema é o conjunto de todos os eventos que ocorrem no sistema.

Por exemplo, se $p$ é um processo, então a história local de $p$ é $h_{p}=\left\{e_{1}, e_{2}, e_{3}, \ldots,\right\}$ onde $e_{1}$ é o primeiro evento que ocorreu em $p, e_{2}$ o segundo evento e assim sucessivamente. Genericamente, se $h_{1}$ é a história local do processo $p_{1}, h_{2}$ a de $p_{2}, \ldots, h_{n}$ a de $p_{n}$, então a história global do sistema formado por $n$ processos é $\mathrm{H}=\left\{h_{1} \cup h_{2} \cup \ldots \cup h_{n}\right\}$.

O estado local de um processo $p$ é definido pelo estado inicial de $p$ adicionado de sua história local. Um estado global de um sistema distribuído observado por um processo é o conjunto dos estados locais de todos os processos do sistema.

Um corte em uma computação distribuída é um conjunto $\mathrm{C}=\left\{h_{1} \cup h_{2} \cup \ldots \cup h_{n}\right\}$ onde $h_{i}$ é a história local do processo $p_{i}$. Um corte $\mathrm{C}$ é dito consistente se para todos os eventos $e$ e $e$, temos: se $e \in \mathrm{C}$ e $e^{\prime} \rightarrow e$ então $e^{\prime} \in \mathrm{C}$, isto é, para cada evento pertencente ao corte $\mathrm{C}$, todos os eventos casualmente precedentes também pertencem ao corte.

A figura 1.5 ilustra uma computação distribuída constituída por quatro processos. Destacamos dois cortes: C um corte consistente e C' um corte inconsistente (os eventos relacionados ao envio da mensagem $m$ não satisfazem a condição acima).

Um estado global observado por um processo forma um estado global consistente se corresponder a um corte consistente. Por exemplo, o estado global $G_{C}$ formado pelo corte consistente $\mathrm{C}$, ilustrado na figura 1.5, representa um estado global consistente.

O estado de um canal de comunicação entre os processos $p$ e $q$ é formado pelo conjunto de mensagens enviadas por $p$ a $q$, mas que ainda não foram entregues a $q$. Este conceito representa o fato de que em um dado momento de uma computação distribuída pode haver mensagens em 


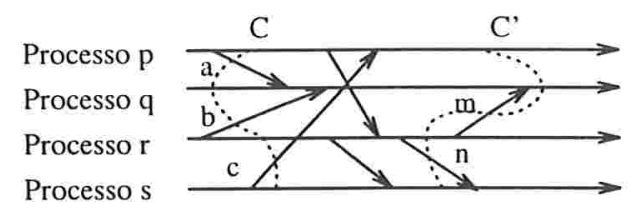

Figura 1.5: Cortes consistente (C) e inconsistente(C')

trânsito entre processos remetentes e receptores.

O estado de todos os canais de comunicação correspondentes a um estado global G consiste de todas mensagens enviadas mas ainda não recebidas em G. Por exemplo, de acordo com a ilustração 1.5 , o estado dos canais de comunicação correspondente ao estado global $G_{C}$ é formado pelas mensagens $a, b$ e $c$.

Os próximos conceitos são importantes para descrever os métodos de checkpointing que estudaremos ao longo do texto. Todos eles estão relacionados com a obtenção e recuperação do estado salvo durante a fase de restabelecimento de estado da nova instância de um processo faltoso.

O checkpoint local de um processo de aplicação corresponde a seu estado local salvo em disco. O ato de obter o checkpoint local será denominado checkpointing. O trecho no código da aplicação onde as rotinas de obtenção do checkpoint local serão invocadas será denominado checkpoint.

É importante notar que um processo pode sofrer uma falha durante a fase de checkpointing, o que inviabiliza a existência de apenas um checkpoint local por processo. Portanto, métodos de checkpointing devem manipular ao menos dois checkpoints locais, um em fase de efetuação (denominado candidato a checkpoint) e outro completamente salvo (denominado checkpoint permanente) relativo à última operação completa de checkpointing efetuada pelo processo.

Algumas técnicas de checkpointing assumem que os processos intercalam fases de comunicação com fases de computação local e que o estado local é determinístico e depende unicamente do último checkpoint local permanente e das mensagens recebidas a partir deste checkpointing.

Neste contexto dizemos que ao final de cada fase de computação local, um processo atinge um estado local consistente, pois seu estado pode ser reconstruído a partir do estado local consistente anterior e do reprocessamento das mensagens recebidas na fase de comunicação mais recente.

Uma vez que é caro e desnecessário salvar todas as informações que caracterizam o comportamento de um processo, é preciso identificar o que deve ser incluído em um checkpoint local para garantir um restabelecimento completo da execução. Para tanto, enunciamos três conceitos que caracterizam vários tipos de informações relacionadas ao estado local dos processos.

O estado relevante de um processo consiste do conjunto de informações que garante o restabelecimento completo de sua execução, a partir do checkpoint local mais recente.

O estado volátil de um processo consiste da pilha de execução do programa, segmentos estáticos e dinâmicos de dados e estruturas essenciais do núcleo do sistema operacional, tais 
como, apontadores de pilha, descritores de arquivos abertos e o contador da instrução corrente, entre outros. Também fazem parte do estado volátil as variáveis manipuladas pelo código da aplicação (contadores de loop, operandos utilizados em cálculos) e estruturas de dados diversas tais como listas ligadas.

É notório que o estado volátil de um processo deve fazer parte de seu estado relevante, caso contrário, o estado local do processo não estaria representado de forma completa e correta. Portanto, o estado relevante pode conter dados relativos ao sistema operacional, bem como, variáveis e estruturas de dados relativas ao programa da aplicação.

No capítulo 2 estudaremos alguns métodos de checkpointing e veremos que algumas técnicas aumentam a instrumentação do código da aplicação com o intuito de diminuir o conteúdo do estado relevante. Por exemplo, pode-se utilizar um método particular de checkpointing em que os dados relativos ao sistema operacional não façam parte do estado volátil, o que diminui sensivelmente o volume do estado relevante em detrimento de uma maior instrumentação do código da aplicação.

O estado persistente de um processo consiste do conteúdo de todos os arquivos abertos e em uso pelo processo.

Wang et. al. [41] discutem se o estado persistente de um processo deve ou não fazer parte do estado relevante. Através de várias argumentações, concluem que a inclusão destes estados pode ser parcial ou total, dependendo do tipo de aplicação. Outra contribuição dada pelos autores é a descrição de uma técnica que inclui totalmente o estado persistente no estado relevante.

Os mecanismos básicos de checkpointing definidos em Sampa propiciam tolerância a falha a processos de aplicação utilizando o nível 2 definido por Huang e Kintala (veja classificação na seção 1.1). Portanto, o estado persistente não fará parte do estado relevante. No capítulo 4 especificaremos detalhadamente o conteúdo do estado relevante e demais características do checkpointing definido no Sampa e implementado em nosso protótipo. 


\section{Capítulo 2}

\section{Métodos de restabelecimento de estado}

Neste capítulo analisamos duas técnicas de restabelecimento de estado denominadas checkpointing coordenado ou distribuído e checkpointing assíncrono. Iniciamos o capítulo com uma motivação comum a ambos os métodos e, em seguida, apresentamos uma pequena classificação procurando diferenciá-los de acordo com participação do programador na obtenção do checkpoint local e na determinação do conteúdo do estado relevante de cada processo. Na última seção discutimos algumas otimizações que podem ser utilizadas para minimizar alguns dos custos intrínsecos a métodos de checkpointing discutidos na seção 1.4 .

\subsection{Motivação}

Em sistemas onde os processos não efetuam comunicação, os mecanismos de tolerância a falha baseados em checkpointing são relativamente simples, pois basta cada processo efetuar checkpoints periódicos durante a fase de processamento normal, e quando uma falha for detectada, é suficiente retomar a execução da nova instância a partir do último checkpoint local armazenado. Isto reconstrói corretamente o estado da nova instância do processo faltoso. No entanto, em sistemas onde os processos efetuam comunicações diversas, o restabelecimento de estado é muito mais complexo. Por exemplo, suponha um sistema formado por três processos, $p, q$ e $r$, conforme ilustrado na figura 2.1 .

Se o processo $q$ sofrer uma falha no ponto indicado, a nova instância $q$ ' deverá retomar a execução a partir do último checkpointing $c p_{q}$ efetuado por $q$. Com isto $q$ ' receberá novamente a mensagem $m$ de $r$, forçando $r$ a retomar a execução a partir do último checkpointing, $c p_{r}$. Da mesma forma, $r$ espera pela mensagem $a$ enviada pelo processo $p$, forçando-o a retomar a execução a partir do checkpointing $c p_{p}$. Este excesso de retomadas de execução é conhecido como efeito dominó. 


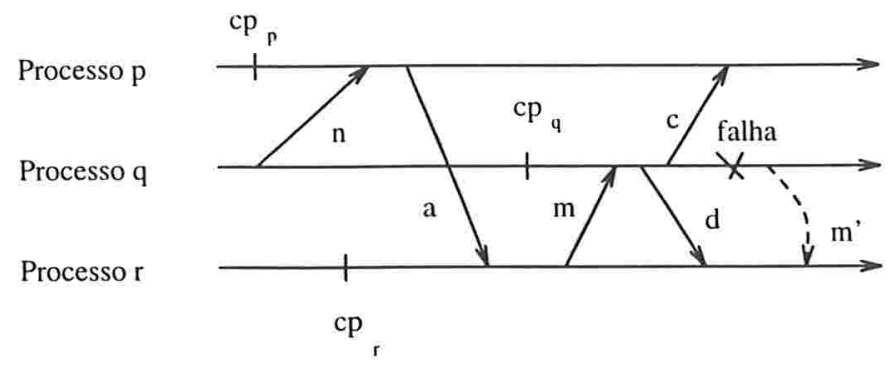

Figura 2.1: Efeito dominó

De um modo geral, a existência de comunicação entre os processos, a dependência causal entre as mensagens enviadas e recebidas e os eventos locais tornam necessário o restabelecimento de execução de vários processos na presença de uma falha, característica esta indesejada em qualquer sistema. No entanto, se apenas o processo faltoso retomar a execução, os demais processos poderiam, eventualmente, continuar a execução causando os seguintes problemas:

- Processos poderiam estar usando informações incorretas, caso a falha seja propagada. Por exemplo, poderíamos ter uma situação onde o processamento de $r$ estivesse estritamente ligado a uma mensagem $m$ ' enviada por $q$. Como $q$ não enviou $m$ ', então $r$ poderia continuar a execução a partir de um estado inválido;

- Informações poderiam se tornar perdidas, caso os demais processos não enviem à nova instância as mensagens anteriormente remetidas ao processo faltoso. Por exemplo, se a falha em $q$ não for combinada com um novo envio de $m$ por $r$ à nova instância, então $m$ se tornaria uma mensagem perdida, já que o remetente $r$ a enviou mas ninguém a recebeu;

- Se apenas o processo $q$ retomar a execução a partir do último checkpointing, então os processos $p$ e $r$ receberiam novamente as mensagens $c$ e $d$ ocasionando duplicidade de mensagens.

Ao longo deste capítulo estudaremos dois métodos de checkpointing que implementam soluções distintas para evitar este e outros problemas intrínsecos a sistemas distribuídos.

\subsection{Classificação geral}

Nesta seção classificamos os métodos de restabelecimento de estado em duas categorias. A primeira delas foge ao âmbito deste trabalho e por isso apresentamos duas referências bibliográficas que descrevem com maior detalhes suas principais características. A segunda engloba mecanismos de restabelecimento baseados em checkpointing, onde justamente este trabalho se concentra.

Podemos classificar os métodos de restabelecimento de estado de processos a nível de aplicação da seguinte forma: 
Restabelecimento para frente. Uma vez detectada uma falha em um processo, este efetua um tratamento de exceção e restabelece seu estado [24, 26]. Este método é muito dependente da implementação do programa da aplicação, uma vez que o restabelecimento para frente deve ser explicitamente programado, isto é, requer a construção de rotinas para tratar erros específicos.

Restabelecimento baseado em checkpointing. Este método é mais genérico e consiste em armazenar periodicamente o estado local dos processos durante o período de execução normal do sistema. Quando ocorrer uma falha em algum processo, o restabelecimento de estado é feito através da execução de uma nova instância a partir do último checkpoint local efetuado pelo processo faltoso.

De um modo geral, a obtenção dos checkpoints locais e o restabelecimento do sistema podem ser feito de diversas formas. Vejamos algumas delas:

Em relação à participação do programador na obtenção do checkpoint local, temos duas possibilidades:

Técnicas semi-automáticas. O programador especifica pontos de restabelecimento de estado (checkpoints) no código do processo onde os checkpoints locais serão obtidos. Isto pode ser feito a partir de chamadas a uma biblioteca de execução que pode ser gerada com o auxílio de uma linguagem pre-processamento ou através da execução de subrotinas dentro do próprio programa do processo $[8,16]$.

Técnicas automáticas. Em técnicas automáticas não é necessário a especificação de checkpoints por parte do programador, pois, tipicamente, é armazenado em disco uma cópia de todas as informações que caracterizam a execução do processo (tais como espaço de endereçamento, conteúdo da pilha de execução, contador da instrução corrente). Este tipo de facilidade acarreta o aumento do volume do checkpoint local, pois uma série de informações irrelevantes (tais como valores de variáveis temporárias) são gravadas em disco.

Em relação ao conteúdo do estado relevante, temos duas formas:

Checkpointing a nível de aplicação. Neste nível, o checkpoint local inclui apenas dados relativos ao programa de execução, isto é, o valor de variáveis e estruturas de dados que caracterizam o estado do processo em determinados pontos de sua execução. Neste método é responsabilidade do programador definir exatamente as variáveis e estruturas que caracterizam o estado relevante do processo. Uma discussão sobre este tipo de abordagem é encontrada em [13].

Checkpointing a nível de sistema operacional. Neste nível, o estado local é geralmente armazenado de forma automática e transparente ao programador, pois o próprio sistema operacional salva periodicamente uma imagem da memória do processo bem como todas as informações (a nível de kernel) que caracterizam seu estado de execução. Além de requerer a inclusão da capacidade de checkpointing no sistema operacional, este nível de checkpointing é bastante custoso, pois os checkpoints locais dos processos 
tendem a ser volumosos, o que o torna restrito apenas a certos tipos de aplicações. Uma referência sobre este tipo de implementação pode ser encontrada em [19].

Mecanismos de restabelecimento de estado baseados em checkpointing podem ser divididos em duas outras categorias, denominadas genericamente de métodos de checkpointing coordenado ou distribuído e técnicas de checkpointing assíncrono. Embora não seja uma regra geral, é bastante comum encontrar trabalhos relacionados à primeira categoria que descrevem métodos automáticos onde o checkpointing é obtido a nível de sistema operacional, enquanto trabalhos que apresentam métodos de checkpointing assíncrono estão normalmente associados a técnicas semi-automáticas e orientadas a aplicação.

Nas próximas seções, apresentamos dois métodos de checkpointing. O primeiro deles é bastante simples e descreve as principais idéias envolvendo técnicas de checkpointing coordenado. O segundo destaca as principais características dos métodos de checkpointing assíncrono, procurando diferenciá-los do primeiro.

Para finalizar, é importante ressaltar que, conforme estudaremos em detalhes no capítulo 4, o método de checkpointing assíncrono a ser adotado no Sampa emprega um mecanismo semiautomático e o checkpointing é efetuado a nível de processo. É neste contexto que este trabalho se concentrará.

\subsection{Checkpointing coordenado ou distribuído}

Em métodos de checkpointing coordenado ou distribuído todos ou um subconjunto de processos armazenam os estados locais em conjunto, de forma que o conjunto de checkpoints locais formem um estado global consistente. A idéia principal é retomar a execução do sistema a partir de um estado global consistente quando da ocorrência de falha em algum processo.

De acordo com Jalote [29] um conjunto de checkpoints locais $K$ forma um estado global consistente se:

1. O conjunto $K$ contém apenas um checkpoint local por processo.

2. Não existe um evento de envio de mensagem em um processo $p$ posterior a seu checkpoint local $c_{p}$ cujo correspondente evento de recebimento da mensagem pelo processo $q$ ocorra antes do checkpoint local $c_{q}$, para $c_{p}$ e $c_{q}$ pertencentes ao conjunto de checkpoints locais $K$. Isto equivale a dizer que não existem mensagens órfãs no conjunto $K$.

3. Não existe um evento de envio de mensagem em um processo $p$ anterior a seu checkpoint local $c_{p}$ cujo correspondente evento de recebimento da mensagem no processo receptor $q$ ocorra após o checkpoint local $c_{q}$, para $c_{p}$ e $c_{q}$ pertencentes a $K$. Isto equivale a dizer que não existem mensagens perdidas em $K$.

Um conjunto de checkpoints que satisfaça esta condição é chamado de linha de restabelecimento. Métodos de checkpointing coordenado devem, então, retomar a execução do sistema a 
partir da linha de restabelecimento mais recente após a ocorrência de falha em um processo.

Vejamos um exemplo de como utilizar a definição acima para determinar uma linha de restabelecimento no seguinte sistema formado pelos processos $p, q$ e $r$.

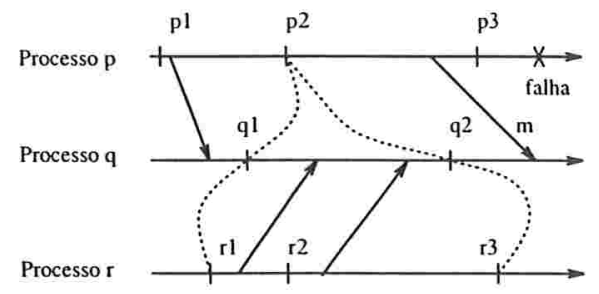

Figura 2.2: Determinando linhas de restabelecimento

Suponhamos que o processo $p$ sofra uma falha no ponto indicado. Se considerarmos os checkpoints locais $p_{3}$ e $q_{2}$ veremos que o envio da mensagem $m$ não satisfaz a condição 3 . No entanto, o conjunto $\mathrm{K}=\left\{p_{2} \cup q_{2} \cup r_{3}\right\}$ satisfaz as três condições, formando, portanto, a linha de restabelecimento mais recente. O conjunto $\mathrm{K}^{\prime}=\left\{p_{2} \cup q_{1} \cup r_{1}\right\}$ também representa um estado global consistente.

\subsubsection{Protocolos de sincronização}

Existem vários protocolos de sincronização de estados utilizados para construir linhas de restabelecimento. Nesta seção descrevemos um protocolo bastante intuitivo proposto e implementado por Elnozahy et. al. [9]. Outros métodos mais complexos podem ser encontrados em $[3,29,37,39]$.

O protocolo parte do princípio de que um processo age como coordenador e envia mensagens aos outros processos para sincronizarem a obtenção do estado global consistente. Cada checkpoint local é identificado por um número denominado ccn (Consistent Checkpoint Number), incrementado a cada rodada do protocolo. Qualquer envio de mensagem entre os processos carrega o valor do contador $c c n$ do remetente.

O protocolo é executado da seguinte forma:

- O coordenador incrementa seu contador ccn e envia mensagens com marcadores [23] que contêm ccn a cada processo do sistema;

- Ao receber a mensagem com marcador, cada processo efetua um checkpointing armazenando seu estado relevante em disco. Cada processo também efetua um checkpointing se receber alguma mensagem cujo $c c n$ anexado é maior que o valor do contador $c c n$ local. Uma vez que tal mensagem foi enviada após seu remetente ter iniciado a gravação do estado local, o receptor deve efetuar o checkpointing antes de processar a mensagem recebida (veja condição 3 na seção anterior).

- Após finalizar a gravação do estado local, cada processo envia uma notificação ao coordenador. 
- O coordenador coleta as notificações recebidas. Se todos conseguiram efetuar o checkpointing com sucesso, este envia uma mensagem informando-os de que está ciente do fato. Caso algum processo não tenha notificado o coordenador, este envia uma mensagem informando a cada processo para descartar o checkpoint local recém obtido.

Este protocolo constrói linhas de restabelecimento de acordo com o exemplificado na seção anterior, garantindo, portanto, que o conjunto de checkpoints locais individuais representem um estado global consistente.

\subsubsection{Restabelecimento de estado}

A forma mais simples de restabelecer o estado do sistema na presença de falha é iniciar a execução a partir da linha de restabelecimento mais recente. Uma vez que existe no máximo um checkpoint local por processo e visto que tal conjunto de checkpoints forma um estado global consistente, este método de restabelecimento levará o sistema a um estado consistente.

No entanto, esta técnica não é a forma mais eficiente. Por exemplo, é provável que um dado processo faltoso não tenha efetuado comunicação com todos os processos do sistema, de forma que seja desnecessário restabelecer a execução de todos os processos a partir da linha de restabelecimento mais recente. Para ilustrar esta situação, considere o seguinte sistema formado por três processos.

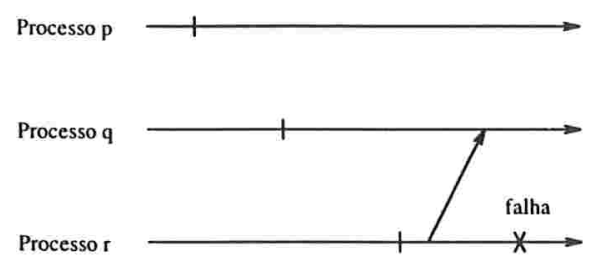

Figura 2.3: Otimização no restabelecimento de estado

Suponhamos que o processo $r$ sofra uma falha no ponto indicado na figura. Ao retomar a execução a partir do último checkpoint local, o envio de mensagem feita por $r$ obriga $q$ a retomar a execução a partir de seu último checkpoint local. No entanto, $p$ não necessita restabelecer seu estado, pois o estado local de $p$ em conjunto com os checkpoints locais dos processos $q$ e $r$ formam um estado global consistente (não existem mensagens órfãs nem mensagens perdidas no estado global em questão). Uma técnica mais complexa que fornece um nível maior de otimização foi proposta por Koo e Toueg em [25].

A vantagem dos métodos de checkpointing coordenado é que o restabelecimento de estado do sistema se torna bastante simples, pois basta cada processo retomar a execução a partir do respectivo checkpoint local determinado pela linha de restabelecimento mais recente e um estado global do sistema estará naturalmente reconstruído. No entanto, é necessário efetuar trocas de mensagens entre os processos para garantir a sincronização no armazenamento dos estados locais, causando uma degradação de desempenho. 


\subsection{Checkpointing Assíncrono}

Em métodos de checkpointing assíncrono, os checkpoints locais são armazenados independentemente e a comunicação entre os processos é rastreada. Quando uma falha é detectada, uma nova instância do processo faltoso retoma a execução a partir do último checkpoint local e as mensagens rastreadas são utilizadas para reconstruir seu estado local $[10,21,38]$.

Nas próximas seções, estudamos as principais idéias envolvendo métodos de checkpointing assíncrono, deixando todos os detalhes para o capítulo 4, onde descreveremos em profundidade o método de checkpointing assíncrono a ser adotado no Sampa.

\subsubsection{Obtenção dos checkpoints locais}

Em métodos de checkpointing assíncrono cada processo armazena seu estado local independentemente, isto é, não é necessária a sincronização de processos para obtenção dos checkpoints locais. A idéia central é obter checkpoints locais consistentes, e não um estado global consistente. A principal vantagem deste tipo de abordagem é que não é necessário utilizar complexos protocolos para garantir que os checkpoints locais reflitam um estado global consistente.

De uma forma geral, o estado local de cada processo é armazenado em disco no momento do checkpointing, embora existam métodos em que os processos enviam seu estado local a entidades centrais encarregadas de gravá-los em disco. O Sampa prevê este tipo de armazenamento centralizado dos estados locais, onde processos daemons serão encarregados desta tarefa, permitindo maior disponibilidade dos processos de aplicação.

Como a meta é obter checkpoints locais consistentes, é importante que, no caso de técnicas semi-automáticas, o programador da aplicação invoque as rotinas de checkpointing em pontos específicos do programa da aplicação onde esteja formado um estado local consistente. É neste contexto que se enquadra o mecanismo de checkpointing adotado no Sampa. No caso de técnicas automáticas, o estado local consistente é obtido sem a intervenção do programador, o que implica um aumento do volume do checkpoint local e da complexidade dos algoritmos encarregados de armazená-los.

\subsubsection{Rastreamento de mensagens}

Conforme descrito no início deste capítulo, a existência de comunicação implica que mais de um processo retome a execução a partir do último checkpointing efetuado. A solução para esta situação é garantir que todas as mensagens processadas pela nova instância do processo faltoso estejam disponíveis a partir de um log de mensagens em disco, por exemplo.

No capítulo 3 estudaremos em detalhes duas técnicas de rastreamento de mensagens que disponibilizam todas as mensagens necessárias para reconstruir o estado local da nova instância. A primeira delas, denominada rastreamento de mensagens baseado no remetente, armazena na 
memória local de cada processo remetente todas as mensagens enviadas a qualquer processo do sistema; a segunda armazena todas as mensagens recebidas por um processo, sendo denominada, portanto, método de rastreamento de mensagens baseado no destinatário.

\subsubsection{Restabelecimento de estado}

O restabelecimento de estado de um processo faltoso consiste em iniciar a execução de uma nova instância, ler o conteúdo do estado relevante relativo ao último checkpoint local e reprocessar todas as mensagens recebidas pela instância faltosa desde seu último checkpointing. Por exemplo, no método de rastreamento de mensagens baseado no remetente, a nova instância requisita a todos os processos o envio destas mensagens. No sistema Sampa, os daemons serão os responsáveis por transmiti-las à nova instância.

Na seção 3.2 apresentaremos em detalhes o método de rastreamento de mensagens proposto por Johnson e Zwaenepoel [21], e no capítulo 4, onde especificaremos o mecanismo de checkpointing a ser adotado no Sampa, descreveremos em profundidade a interação entre componentes do sistema desde o momento da deteç̧ão de falha até o completo restabelecimento de estado da nova instância.

\subsection{Otimizações}

Nesta seção estudaremos algumas otimizações que podem ser empregadas em métodos de checkpointing coordenados e assíncronos. A primeira delas tem como objetivo diminuir o volume do estado relevante e minimizar o overhead da operação de checkpointing. A segunda estabelece alguns parâmetros para ajustar a frequência do checkpointing às necessidades das aplicações.

\subsubsection{O volume do estado relevante}

Várias formas de otimização da operação de checkpointing com relação ao tempo gasto, ao volume do checkpoint local e à redundância de informações podem ser aplicadas. Vejamos algumas delas:

Área de memória Se for possível determinar em tempo de compilação quais páginas da memória serão usados pelo programa da aplicação, então o volume do checkpoint local poderia ser reduzido significativamente, pois bastaria salvar apenas um subconjunto do total de memória necessária à execução da aplicação. Infelizmente isto nem sempre é possível e o problema se torna mais complexo no caso da memória ser alocada dinamicamente em tempo de execução. De qualquer forma, na pior das hipóteses, toda a memória deve ser armazenada no checkpoint local.

Incrementação. Quando um processo efetua um checkpointing, não é necessário armazenar todo o conteúdo do estado relevante: basta apenas armazenar a porção que foi alterada 
desde o último checkpointing. Isto reduz o volume do checkpoint local e, consequentemente, o tempo total necessário para armazená-lo, embora a nova instância terá um trabalho maior para lê-lo, uma vez que seu conteúdo estará provavelmente fragmentado em vários arquivos. Implementações de checkpoint incremental podem ser encontradas em [11, 19].

Compressão. Outra técnica frequentemente utilizada na redução do volume do checkpoint local e da redundância de informações é a compressão de dados. Embora intuitivamente esta técnica não ofereça maiores problemas, deve-se fazer uma pequena ressalva: a compressão de dados só deve ser adotada se a velocidade do algoritmo de compressão de dados for maior que a velocidade de gravação de dados em disco e se o algoritmo de compressão adotada reduzir significativamente o tamanho do estado relevante.

Copy-on-write. A hipótese básica deste método é que o sistema operacional ou o sistema de apoio à execução possibilite o gerenciamento de memória descrito a seguir. O método funciona da seguinte forma: imediatamente antes de efetuar o checkpointing, as páginas de memória utilizadas pelo processo são protegidas contra gravação; após todas as páginas serem armazenadas em disco, a proteção de memória é retirada. Se for feita uma tentativa de alterar o conteúdo de qualquer uma destas páginas enquanto estiverem protegidas, uma falha de proteção de memória é gerada.

$\mathrm{Na}$ verdade, o núcleo do sistema operacional copia o conteúdo de cada página protegida para uma nova página de memória e remove a proteção da página original possibilitando ao processo escrever nas páginas que utiliza. A nova página alocada não é acessível ao processo, mas sim a um gerenciador de checkpoint que gravará seu conteúdo em disco, e depois a desalocará. Caso não exista memória suficiente para alocar uma nova página de memória auxiliar, o processo original é bloqueado até que exista espaço para a alocação.

A vantagem deste método é permitir a continuidade de execução do processo enquanto o estado relevante é armazenado em disco reduzindo, consequentemente, o tempo total da operação.

\subsubsection{Frequência do checkpointing}

Um aspecto importante a ser analisado é a frequência de efetuação do checkpointing, pois isto causa um impacto imediato no tempo total de execução dos processos. E mais, quanto maior for o intervalo entre um checkpointing e outro, maior será a quantidade de trabalho desperdiçado no caso de uma falha. Isto é uma preocupação fundamental em sistemas de tempo real.

Existem dois parâmetros que auxiliam na escolha de um intervalo de checkpointing conveniente. Vejamos:

Taxa de falha do sistema. Obviamente, quanto maior for a taxa de falha de um sistema, menor deve ser o intervalo de checkpointing. Isto permite que uma quantidade menor de trabalho seja desperdiçada quando ocorrer uma falha. 
Tempo de checkpointing Quanto maior for o tempo necessário para efetuar um checkpointing, maior deve ser o intervalo do mesmo. Isto é importante para que o tempo total de execução dos processos não aumente em demasia.

Diversas técnicas são utilizadas para ajustar o comprimento do intervalo de cada checkpointing. Dentre elas, citamos:

- Determinação por parte do programador de onde o checkpointing será efetuado (no caso de técnicas de checkpoint semi-automáticas);

- Invocar a rotina de checkpoint após $t$ batidas do relógio local da aplicação. Esta técnica é bastante útil em métodos de checkpointing automáticos;

- Realizar o checkpoint após $k$ mensagens enviadas.

\subsection{Implementações de checkpointing}

Podemos encontrar algumas implementações de mecanismos de tolerância a falha usando diferentes métodos de checkpointing. A seguir resumimos as características dos principais projetos:

CONDOR. CONDOR [1] é um sistema para gerenciamento de recursos distribuídos desenvolvido pelo grupo CONDOR na Universidade de Wisconsin, Madison. As facilidades de checkpointing em CONDOR são obtidas através de bibliotecas de execução, denominadas condor libraries, que incluem um signal handle para efetuar checkpointing assíncrono de processos em ambiente UNIX. Dentre as principais características deste trabalho, estão a inclusão do espaço de endereçamento, da pilha de execução, e dos arquivos abertos e em uso pelos processos no estado relevante. Além disso, a biblioteca de checkpointing manipula os signal's handles em uso pelos processos, permitindo, assim, tratar possíveis sinais bloqueados ou suspensos temporariamente durante a efetuação do checkpointing.

Libckpt. Plank et. al. apresentam a biblioteca de checkpointing assíncrono libckpt [19] que utiliza diversas facilidades do UNIX para implementar tolerância a falha ao nível de aplicação. Libckpt apresenta diversas otimizações tais como checkpointing incremental, compressão de dados, forked checkpoint, exclusão de memória e uma técnica desenvolvida pelos autores que parte do princípio de que, com um pequeno número de informações fornecidas pelo usuário a respeito da aplicação, é possível aumentar significativamente o desempenho do checkpointing.

Libckp. Wang et. al. descrevem diversos aspectos da biblioteca libckp [41] para checkpointing assíncrono de processos em ambiente UNIX. As principais características desta biblioteca são a inclusão dos arquivos manipulados pela aplicação no estado relevante dos processos e a possibilidade de efetuar checkpointing automático e manual, de acordo com as necessidades e preferências do usuário. 
Sistemas de memória compartilhada distribuída. Gilbert at. el. [6] descrevem o método de checkpointing coordenado implementado para aplicaçōes paralelas que executam em sistemas DSM[27]. A idéia central do trabalho é efetuar o checkpointing dos processos pertencentes a uma aplicação paralela após a formação de uma barreira de sincronização, pois, neste instante, os processos possuem um estado local consistente formado. O método de checkpointing também inclui algumas otimizações tais como checkpoint incremental e copy-on-write.

Checkpoint em DOME. DOME [14] é um ambiente para migração de objetos distribuídos que permite a execução de programas paralelos em um ambiente tolerante a falha. A implementação de checkpointing ao nível de aplicação [13] apresentada em DOME é bastante parecida com o que está proposto em Sampa, conforme veremos em detalhes na seção 4.1.1. De uma forma geral, o programador da aplicação declara as variáveis que fazem parte do estado relevante através de diretivas de pre-processamento e faz chamadas às rotinas de checkpointing no momento em que o estado local da aplicação for consistente. 


\section{Capítulo 3}

\section{Métodos de rastreamento de mensagens}

Os métodos de rastreamento de mensagens descritos a seguir são específicos para uso em conjunto com métodos de checkpointing assíncrono. Sua função é possibilitar a reconstrução completa do estado local da nova instância em substituição ao processo faltoso da seguinte forma: uma vez detectada uma falha em algum processo $p$, uma nova instância $p$ ' é iniciada em alguma máquina a partir do último checkpoint local $c p$. Possíveis mensagens existentes nos canais de comunicação no instante em que $c p$ foi obtido e todas as mensagens enviadas a $p$ até o momento da falha devem ser reprocessadas pela nova instância $p^{\prime}$. Após o reprocessamento, o estado local da nova instância será idêntico ao estado local da instância morta $p$ no momento imediatamente anterior a sua falha.

Portanto, a premissa principal dos métodos de rastreamento de mensagens é que os processos devem ser determinísticos, isto é, a partir de um mesmo padrão de interação deve ser possível chegar ao mesmo estado local do processo no momento anterior à morte.

Outra hipótese dos métodos de rastreamento é que todo processo se comunica exclusivamente através do envio assíncrono de mensagens. Isto é necessário porque a reconstrução de estado é baseada apenas na leitura do último checkpoint local e no reprocessamento de mensagens rastreadas.

\subsection{Métodos otimistas e pessimistas}

Os métodos de rastreamento de mensagens podem ser classificados em duas categorias:

Pessimistas ou síncronos Nesta classe, todo processo remetente interrompe momentaneamente a execução após cada envio de mensagem para que uma cópia da mensagem enviada seja gravada em disco. Em $[5,30]$ há uma descrição detalhada de dois sistemas que adotam 
este tipo de metodologia.

Otimistas ou assíncronos Em métodos de rastreamento otimistas, os processos continuam o processamento normal após cada envio de mensagem e as cópias são armazenadas em disco durante o período de ociosidade da aplicação.

A seguir estudamos dois métodos otimistas de rastreamento de mensagens, dando ênfase ao primeiro, por se adaptar às necessidades e definições do projeto Sampa. O segundo será apresentado brevemente, já que as principais características e funcionalidades são semelhantes ao primeiro método.

\subsection{Rastreamento baseado no remetente}

A idéia central do método proposto por Johnson e Zwaenepoel [21] é efetuar um rastreamento de mensagens enviadas armazenando-as na memória local de cada processo remetente, tornando-as disponíveis para retransmissão quando um processo receptor de mensagens (denominado também processo destinatário) sofrer uma falha.

\subsubsection{Informações e estruturas de dados}

As informações e estruturas de dados utilizadas pelo método são estas:

- Cada processo possui um contador de mensagens enviadas, denotado por ssn (Sender Sequence Number). A utilidade deste contador é detectar e eliminar mensagens duplicadas durante o restabelecimento de estado de um processo receptor faltoso;

- Todo processo mantém um contador de mensagens recebidas, denominado rsn (Receiver Sequence Number). Este contador é incrementado toda vez que uma mensagem é recebida. Após a atualização, o rsn é retornado ao remetente da mensagem, para que possa associar de forma unívoca o rsn recebido à mensagem enviada.

- Todo processo possui um $\log L$ de mensagens enviadas. Inicialmente, cada mensagem enviada permanece temporariamente na memória local do remetente, e de forma assíncrona é armazenada no $\log L$ em disco no momento do checkpointing. Cada elemento neste $\log L$ contém a seguinte tupla: m:ssn:rec:rsn, onde $m$ é a mensagem enviada pelo remetente ao receptor rec, ssn é o número de sequência de envio de $m$ (dado pelo remetente) e $r s n$ é o número de recebimento de $m$ atribuido pelo destinatário. Note que o rsn é necessário para que a nova instância de um destinatário faltoso possa receber as mensagens reprocessadas na mesma ordem em que o processo faltoso as recebeu;

- Cada processo (receptor) mantém uma tabela $T$ contendo o maior valor $s s n$ recebido de cada processo remetente com o qual realizou alguma comunicação. Esta tabela é usada na deteç̧ão e rejeição de mensagens duplicadas; 
- Cada processo receptor mantém uma tabela contendo o valor rsn retornado a cada mensagem recebida desde o último checkpointing. Esta tabela deve ser indexada pelo ssn da mensagem e pode ser esvaziada após o checkpointing. Esta informação é útil para que a unicidade entre os valores $r s n$ e as correspondentes mensagens seja sempre preservada durante o restabelecimento de estado de um receptor faltoso.

\subsubsection{O protocolo de comunicação}

Para que seja possível rastrear as mensagens, é necessário que os valores dos contado: ssn e rsn sejam trocados entre o remetente e o receptor através do seguinte protocolo de comunicação confiável, ilustrado pela figura 3.1.

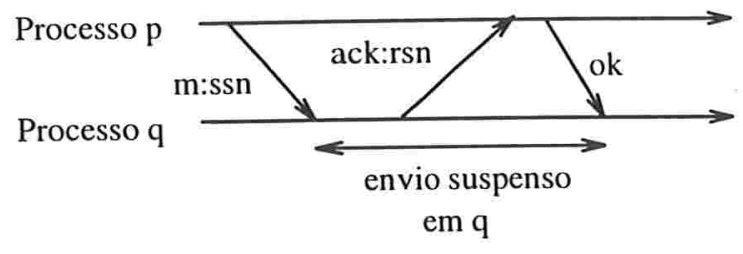

Figura 3.1: Protocolo de comunicação confiável

Sejam $p$ e $q$ dois processos. Suponhamos que $p$ deseje enviar a mensagem $m$ ao processo $q$. Para tanto, $p$ incrementa seu contador $s s n$, anexa este novo valor a $m$ e envia o conjunto $m: s s n$ a $q$. Além disso, $p$ armazena em seu $\log L$ a tupla m:ssn:rec, onde rec é o binding de $q$ ao qual $m$ foi destinada. Esta tupla será chamada de mensagem parcialmente armazenada (no remetente).

Ao receber $m, q$ incrementa seu contador rsn e retorna a $p$ uma notificação de recebimento ack com o valor rsn anexado. Além disso, $q$ suspende, temporariamente, o envio de qualquer mensagem, mas continua a realizar todas as suas outras operações, tais como, completar o protocolo para qualquer mensagem recebida.

Ao receber notificação $a c k, p$ executa duas tarefas. Inicialmente, anexa o valor $r s n$ à entrada de $m$ no seu log de mensagens $L$, obtendo a tupla m:ssn:rec:rsn, denominada mensagem totalmente armazenada (no remetente). Finalmente, $p$ envia uma notificação $o k$ a $q$ indicando que a mensagem foi completamente armazenada.

Deve-se notar que podem existir mensagens parcialmente armazenadas nos processos remetentes, pois é possível um processo receptor falhar antes de enviar o rsn de volta. Portanto, o log de mensagens em cada processo consistirá de dois tipos de entradas: as mensagens totalmente armazenadas, identificadas por m:ssn:rec:rsn, e as mensagens parcialmente armazenadas, identificadas por m:ssn:rec.

Finalizando o protocolo, ao receber a notificação $o k, q$ retoma o envio de mensagens, até então, suspenso temporariamente. 


\subsubsection{Restabelecimento de estado}

Quando algum processo sofre uma falha do tipo fail-stop, o seguinte protocolo de reprocessamento de mensagens deve ser utilizado para restabelecer o estado da nova instância.

Seja $p$ um processo faltoso. Inicialmente, uma nova instância $p$ 'é criada em alguma máquina disponível, a partir de seu checkpoint local permanente. A seguir, $p$ ' efetua um broadcast requisitando a todos os processos o envio de qualquer mensagem anteriormente destinada à instância faltosa. Como resultado do pedido, em um primeiro instante, apenas as mensagens totalmente armazenadas são enviadas e consumidas por $p^{\prime}$, em ordem crescente de rsn. Em seguida, as mensagens parcialmente armazenadas são enviadas a $p^{\prime}$ ' e consumo é feito em qualquer ordem.

\subsubsection{Comentários adicionais}

Uma vez descritos os protocolos de comunicação confiável e de reprocessamento de mensagens, pode-se derivar as seguintes conclusões:

Uma vez detectada falha em um processo $p$, não é permitido que ocorra falha em outro processo até que a nova instância $p$ ' restabeleça por completo seu estado. Isto pode ser visto da seguinte forma: quando $p$ sofre falha, todos os processos do sistema devem transmitir à nova instância $p$ ' qualquer mensagem enviada anteriormente a $p$. Portanto, se dois processos falham ao mesmo tempo, eventualmente não será possível retransmitir todas as mensagens necessárias.

É fundamental que as mensagens totalmente armazenadas sejam consumidas pela nova instância antes das mensagens parcialmente armazenadas. Para verificar isto, basta notar que as mensagens do primeiro tipo foram processadas pela instância morta antes da falha, determinando um caminho de execução estritamente relacionado à ordem de consumo. Portanto, se o reprocessamento não for feito nesta mesma ordem, a nova instância realizará, com grande probabilidade, um novo caminho de execução, impedindo o correto restabelecimento. As mensagens parcialmente armazenadas, por outro lado, ainda não determinaram um caminho de execução e, portanto, podem ser consumidas pela nova instância em qualquer ordem.

A suspensão temporária do envio de novas mensagens pelo processo receptor $q$ antes do recebimento da confirmação $o k$ (veja figura 3.1) é necessária para manter consistentes as dependências entre as mensagens. Por exemplo, suponhamos um sistema formado por três processos $p, q$ e $r$ conforme ilustração 3.2 .

O processo $p$ envia a $q$ a mensagem $m$. Conforme definido no protocolo de comunicação confiável, $q$ deve suspender o envio de novas mensagens (no trecho B indicado na figura) até receber a confirmação $o k$ de $p$. Suponhamos que ele não aja desta forma, e envie a $r$ a mensagem $m$ ' logo após receber $m$, estabelecendo, portanto, uma dependência causal entre as duas mensagens.

Suponhamos, agora, que o processo receptor $q$ sofra uma falha no instante $\mathrm{F}$ logo após enviar $m^{\prime}$. A liberdade no consumo das mensagens parcialmente armazenadas pode quebrar a dependência entre $m$ e $m$ '. Por exemplo, após consumir as mensagens totalmente armazenadas, $q$ ' pode receber de $r$ a mensagem $m$ ", forcando-o a tomar um caminho de execução distinto do 


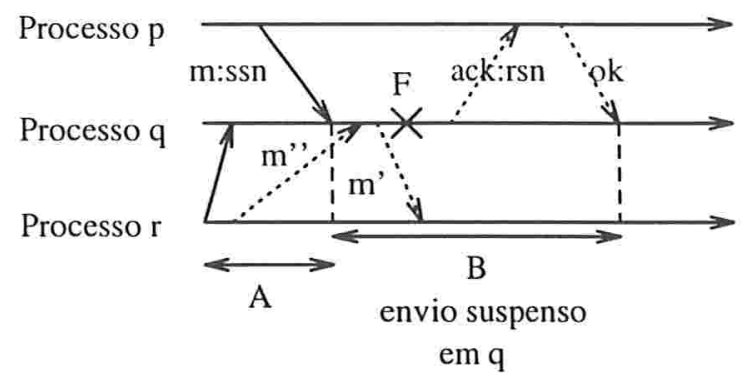

Figura 3.2: Suspensão temporária do envio de mensagens pelo processo receptor

estabelecido pela instância morta, evitando o envio de $m^{\prime}$ a $r$, tornando-a uma mensagem orfã.

Todas as mensagens destinadas a um processo e consumidas antes do último checkpointing podem ser removidas dos logs nos respectivos processos remetentes. Para verificar isto, basta notar que uma vez ocorrida uma falha, a retomada de execução é feita a partir do último checkpoint local permanente, de forma que as mensagens anteriores a este ponto não serão mais usadas no reprocessamento. Note que isto não inclui as mensagens pertencentes aos canais de comunicação no momento do checkpointing. A figura 3.3 mostra que as mensagens $a$ e $b$ podem ser descartadas dos logs dos remetentes $p$ e $r$, respectivamente, mas as mensagens $m$ e $n$ devem estar disponíveis para reprocessamento.

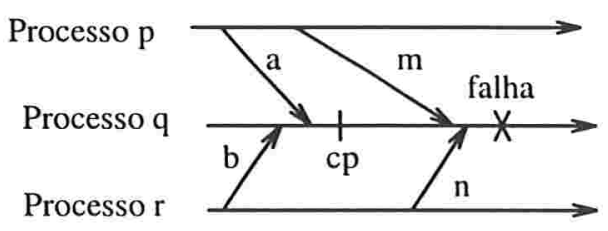

Figura 3.3: Processo de remoção das mensagens dos logs dos remetentes

Uma forma de implementar a remoção destas mensagens supérfluas dos logs utilizando o protocolo de comunicação confiável, é fazer com que o processo receptor envie uma informação extra quando retornar o rsn ao remetente, especificando qual é o valor do rsn relativo ao último checkpoint local permanente (chamemos este valor de rsnp). Isto permite ao remetente remover todas as entradas que possuam rsn inferior a rsnp, possibilitando uma "coleta de lixo" no log, impedindo que eles cresçam indefinidamente.

Quando a nova instância p' estiver retomando a execução, a hipótese de determinismo em conjunto com a ordem de reprocessamento das mensagens do broadcast farão $p$ ' enviar mensagens duplicadas ao ambiente de execução. Na seção 3.2.1 descrevemos duas informações importantes que permitem a deteç̧ão e eliminação deste tipo de mensagens: a primeira nos diz que toda mensagem possui um único valor de ssn (o que garante que as mensagens retransmitidas pela nova instância $p^{\prime}$ tenham os mesmos valores de $s s n$ das mensagens enviadas por $p$ ); a segunda supõe que todo processo $q$ possui uma tabela $T$ contendo os maiores valores ssn ordenado por remetente. Portanto, quando a nova instância $p$ ' enviar uma mensagem $m$ a um receptor $q$, este terá em sua tabela $T_{q}$ qual foi o último valor ssn recebido de $p$ (ou $p^{\prime}$ ) e poderá descartar $m$ 
como mensagem duplicada.

\subsubsection{Características do método}

Podemos resumir as principais características do método descrito da seguinte forma:

- O checkpointing de cada processo é obtido de forma assíncrona em relação aos checkpointings dos demais processos;

- Quando um processo $p$ sofre uma falha, é suficiente restabelecer apenas o estado da nova instância p' a partir do último checkpoint local permanente. Os demais processos do sistema permanecem em execução normal;

- Esta técnica distribui o gasto adicional de armazenamento das mensagens proporcionalmente entre todos os processos remetentes;

- É evitado o armazenamento centralizado das mensagens trocadas entre os processos. Isto é especialmente interessante porque evita a preocupação com uma possível falha no processo central encarregado de armazená-las em disco.

As principais desvantagens deste método são:

- O tráfico de mensagens aumenta por causa das confirmações. No entanto, isto possibilita a implementação deste protocolo em ambientes onde não exista um protocolo de comunicação confiável;

- Existe um overhead de tempo e espaço associado ao armazenamento de informações adicionais (mensagens, ssn e $r s n$ ) nos remetentes.

\subsection{Rastreamento baseado no destinatário}

De um modo geral, neste método o sistema operacional mantém uma fila de mensagens para cada processo. As mensagens recebidas por um processo $q$ são armazenadas em sua memória local temporariamente, e de forma assíncrona e independentemente da computação realizada por $q$ são transferidas para o disco como parte do checkpoint local. Ou seja, o log de mensagens é armazenado nos processos receptores.

Vejamos a descrição do protocolo proposto por Huang et. al. [18] através de um exemplo. Suponhamos um sistema formado por três processos, conforme ilustração 3.4, onde o processo $q$ efetua um checkpointing no instante $c p$ e sofra uma falha no instante $f$. Neste sistema, os processos $p$ e $r$ serão os remetentes encarregados de fazer a retransmissão de mensagens à nova instância $q$ ' durante o restabelecimento de estado. 


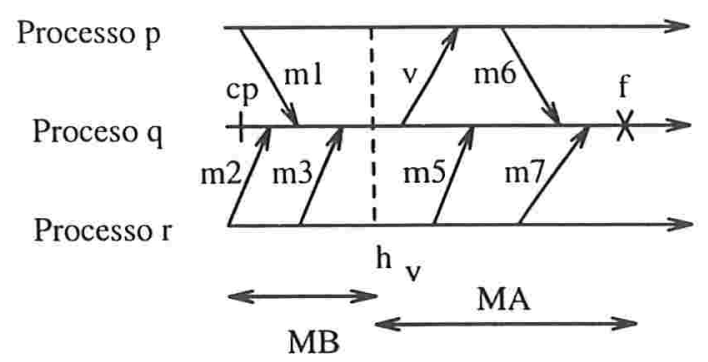

Figura 3.4: Rastreamento de mensagens baseado no receptor

Da mesma forma como foi feito no método anterior, dividimos o conjunto de mensagens enviadas e recebidas por $q$ em duas partes, da seguinte forma: seja $v$ a última mensagem enviada por $q$ antes de sofrer a falha, e seja $h_{v}$ a linha vertical determinada em função $v$, conforme ilustração. Esta linha particiona o conjunto de mensagens em duas regiões: o conjunto MB é formado pelas mensagens que $q$ recebeu antes do envio de $v$, isto é, formado pelo conjunto de mensagens casualmente precedentes a $v$. O conjunto MA é formado pelas mensagens que $q$ recebeu após enviar $v$ adicionado das mensagens existentes em sua fila, mantida pelo sistema operacional.

A retomada de execução da nova instância $q$ ' é feita em duas partes. Inicialmente, $q$ ' lê o último checkpoint local permanente e, em seguida, consome as mensagens recebidas desde o último checkpoint local $c p$ da seguinte forma: todas as mensagens consumidas por $q$ antes do envio de $v$, isto é, as mensagens pertencentes a MB, devem ser consumidas na mesma ordem; as mensagens pertencentes a MA podem ser consumidas em uma ordem qualquer, desde que seja respeitada a ordem em que foram enviadas por cada processo remetente. Exemplificando, a nova instância deverá consumir $m_{5}$ antes de $m_{7}$. O motivo principal para que isto seja feito desta forma é evitar que outros processos tenham que restabelecer a execução a partir de seus respectivos checkpoints locais.

No exemplo ilustrado na figura 3.4, $q$ é o processo faltoso, $c p$ é o ponto a partir do qual a nova instância $q$ ' retomará a execução, e a mensagem $v$ determina a linha vertical $h_{v}$. As mensagens pertencentes a $\mathrm{MB}=\left\{m_{1}, m_{2}, m_{3}\right\}$ devem ser consumidas pela nova instância $q$ ' na ordem $\left(m_{2}, m_{1}, m_{3}\right)$, e as mensagens pertencentes a $\mathrm{MA}=\left\{m_{5}, m_{6}, m_{7}\right\}$ podem ser recebidas em qualquer ordem, preservando-se a ordem total de envio por processo.

As vantagens deste método de rastreamento de mensagens são similares às vantagens do método anterior, enquanto que a principal desvantagem é a manutenção de uma fila de mensagens a nível de sistema operacional. 


\section{Capítulo 4}

\section{Checkpointing a ser adotado no Sampa}

Neste capítulo especificamos detalhadamente o mecanismo de checkpointing a ser adotado no projeto Sampa. Iniciamos descrevendo o método de checkpointing assíncrono e suas limitações. Em seguida, descrevemos as interações entre as componentes do sistema durante a fase de processamento normal, de detecção de falhas e de restabelecimento de estado da nova instância. Finalizamos o capítulo analisando as características do método de checkpointing especificado.

\subsection{O método de checkpointing}

Adotaremos em Sampa o checkpointing assíncrono e semi-automático no qual o programador da aplicação especifica as variáveis que fazem parte do estado relevante e define os trechos do código do programa da aplicação onde serão chamadas as rotinas de checkpointing, visando sempre a obtenção de checkpoints locais consistentes.

Este método de checkpointing propicia tolerância a falha no nível 2, donde concluímos que o estado persistente não fará parte do estado relevante. E mais, conforme veremos a seguir, o estado volátil será composto por variáveis e estruturas de dados pertencentes ao código da aplicação, excluindo-se, portanto, quaisquer informações a nível de sistema operacional que caracterizam o estado de execução dos processos de aplicação.

O método de rastreamento de mensagens otimista adotado será uma adaptação do rastreamento de mensagens baseado no remetente proposto por Johnson e Zwaenepoel.

Nas próximas seções, analisamos em detalhes o método de checkpointing e as alterações introduzidas no método de rastreamento de mensagens original. 


\subsubsection{Características do método}

Por se tratar de um método semi-automático, o programador da aplicação deve definir em tempo de projeto quais variáveis devem fazer parte do estado relevante. Para cada variável definida, o programador deve acrescentar um comentário especial após sua declaração que será utilizado pelo pre-processador para gerar procedimentos que codificam seu valor no padrão XDR (External Data Representation) [20]. Este pre-processador deverá ser utilizado para programas escritos na linguagem C. No exemplo descrito na figura 4.1, o comentário predefinido checkpoint_var especifica ao pre-processador que as variáveis i, x e s pertencerão ao estado relevante.

O código da aplicação deve ter um trecho inicial para tratar sua inicialização desta forma: caso seja fornecido um parâmetro adicional na linha de comando, a aplicação deve invocar as rotinas de leitura do estado relevante relativo ao último checkpoint local armazenado em disco, representado pela diretiva read_checkpoint. Caso contrário, realiza as inicializações normais das variáveis do programa.

Após a inicialização da aplicação, tipicamente haverá uma iteração principal que consistirá no processamento original (ilustrado pelo trecho faça_computação) seguido de um checkpointing, representado por make_checkpoint. Na verdade, é possível intercalar um checkpointing com algumas rodadas de computação objetivando a otimização da aplicação.

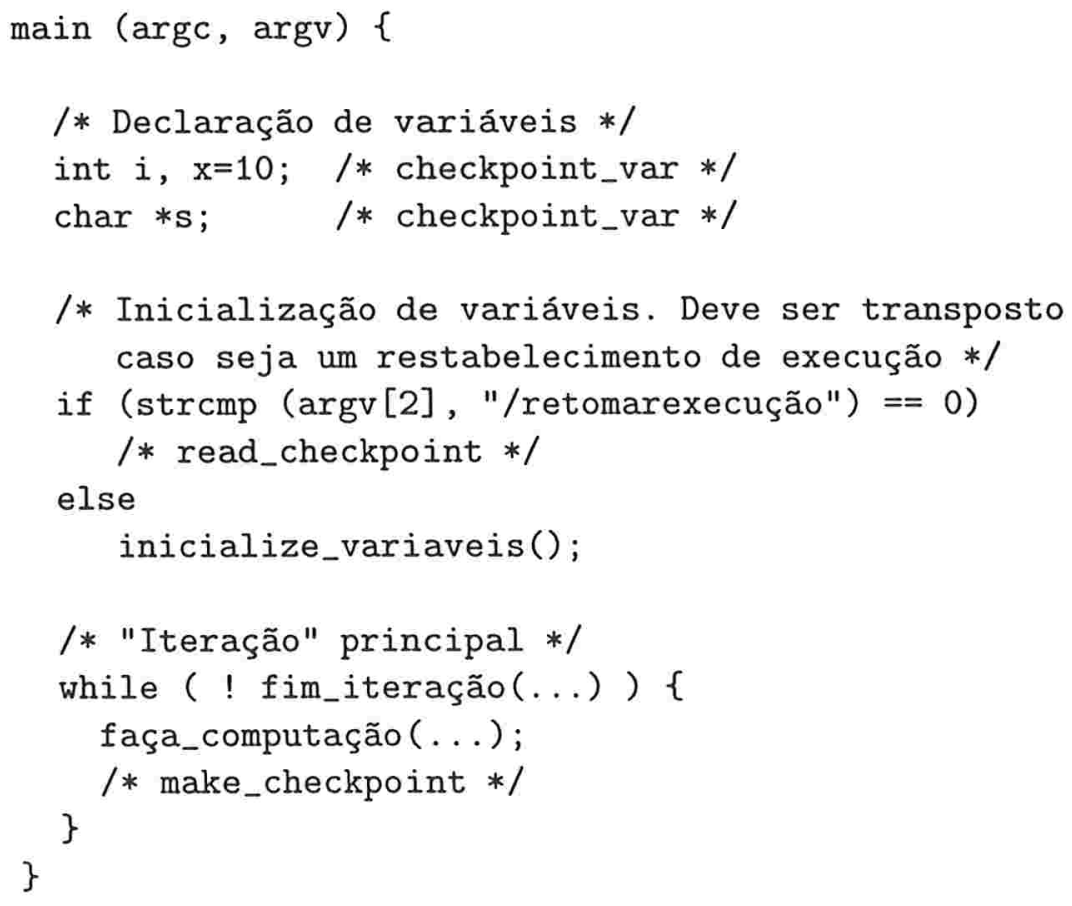

Figura 4.1: Código ilustrando o método de checkpointing 


\subsubsection{Restrições do método}

Basicamente, o método de checkpointing adotado possui duas restrições. A primeira delas é relativa ao contador da instrução corrente. De uma forma geral, é preciso saber, exatamente, que ponto do programa da aplicação estava sendo executado no momento da falha. Para minimizar a dificuldade, supomos que toda a computação esteja definida no trecho faça_computação e que o checkpoint local seja obtido pela diretiva de pre-processamento make_checkpoint, conforme código ilustrado na figura 4.1. Esta restrição faz com que o processo atinja um estado local após faça_computação e que para efeitos de nova instanciação basta conhecer este estado.

A segunda restrição diz respeito à pilha de execução. Quando for efetuado um checkpointing, haverá um conjunto de chamadas a procedimentos e funções ativas, o qual deve ser reconstruído durante a retomada de execução da nova instância. Há dois problemas principais com relação a isto. O primeiro reflete a dificuldade de inspecionar o conteúdo da pilha de execução. O segundo é que mesmo sendo possível, é extremamente difícil reconstruí-la. Para evitar a manipulação da pilha de execução, impomos que a chamada a make_checkpoint ocorra apenas no loop principal do programa da aplicação.

\subsubsection{A técnica de rastreamento de mensagens}

O método de rastreamento de mensagens apresentado por Johnson e Zwaenepoel terá apenas uma modificação quando implementado no Sampa. Todas as demais funcionalidades permanecem conforme definidas no artigo original. Esta modificação consiste em transferir o gerenciamento e armazenamento dos logs de mensagens dos processos para os checkpoint daemons.

Conforme ilustrado na figura 1.3, este novo conjunto de daemons faz parte do serviço básico para checkpointing na arquitetura do sistema Sampa, interagindo com os agentes e o supervisor. As atribuições dos checkpoint daemons são: gerenciar as mensagens enviadas pelos processos locais; armazenar em disco os estados relevantes dos mesmos, evitando que interrompam temporariamente a execução; interagir com os agentes e o supervisor para obter informações sobre o processo morto e a instância substituta; e auxiliar os agentes do sistema durante a retomada de execução da nova instância através da sincronização de ações durante a reprodução de mensagens dos logs locais.

A vantagem da introdução deste novo conjunto de daemons em relação à proposta inicial que previa o armazenamento dos logs de mensagens nos próprios processos de aplicação é que estes podem continuar a realizar a computação normal durante o restabelecimento de execução da nova instância, já que os daemons irão retransmitir as mensagens à nova instância. Uma segunda vantagem é que a ordenação de mensagens em ordem crescente de rsn fica a cargo dos daemons do sistema, diminuindo sensivelmente a instrumentação dos processos de aplicação. Outra vantagem é que a etapa de sincronização de ações durante o restabelecimento de estado torna-se um pouco mais simples de ser manipulada, conforme veremos em breve.

Convém mencionar que a transferência do gerenciamento e armazenamento dos logs de mensagens dos processos para os checkpoint daemons deve ser feita de forma a garantir a integridade 
dos dados no caso de falha em algum daemon. Isto pode ser feito, por exemplo, replicando o estado de cada daemon do sistema em outros daemons, ou fazendo com que, periodicamente, os logs de mensagens sejam armazenados em disco. Neste último caso, os daemons teriam que implementar exatamente o protocolo definido por Johnson e Zwaenepoel para as comunicações efetuadas entre sí.

\subsection{Interação entre as componentes durante o processamento normal}

Vejamos, agora, a interação entre as componentes do ambiente Sampa durante a execução normal do sistema. A figura 4.2 apresenta uma configuração de processos formada por um supervisor na máquina $M_{1}$, um agente e um checkpoint daemon local em cada máquina e sete processos de aplicação, $p_{1}$ a $p_{7}$, onde apenas os processos $p_{1}, p_{2}, p_{4}, p_{5}$ e $p_{7}$ possuem os requisitos de tolerância a falha, isto é, apenas estes processos efetuarão checkpointing e somente eles poderão ter seu estado reconstruído no caso de uma falha.

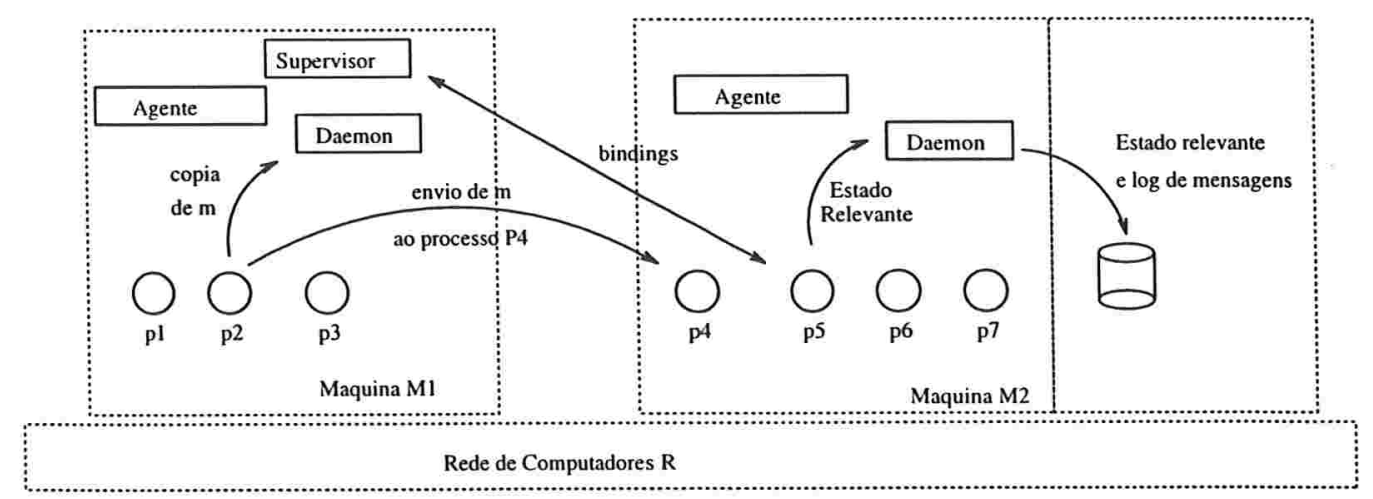

Figura 4.2: Interação entre as componentes do ambiente Sampa

Para permitir o gerenciamento de processos no Sampa, cada processo de aplicação informa ao supervisor os nomes, os tipos e os endereços (bindings) de suas portas de comunicação, bem como os bindings que utilizará ao longo de sua execução imediatamente após o processo ser criado em alguma máquina da rede. Estes últimos bindings não precisam ser necessariamente instanciados neste momento, pois podem ser solicitados (pelo próprio processo ou pelo usuário) ao supervisor ao longo de sua execução. Com isto, o supervisor conhece os bindings e as potenciais conexões de qualquer processo, que poderão ser alteradas dinamicamente pelo usuário ao longo da execução. Por exemplo, o processo $p_{5}$ que executa na máquina $M_{2}$, informa ao supervisor na máquina $M_{1}$ seus bindings. $\mathrm{O}$ processo $p_{2}$ também informa seus bindings ao supervisor e, adicionalmente, indica que durante seu processamento irá se conectar ao processo $p_{4}$ na máquina $M_{2}$.

Com relação à comunicação entre os processos, se $p$ é um processo tolerante a falha que envia uma mensagem $m$ ao processo $q$, então ambos seguirão o protocolo de comunicação confiável descrito na seção 3.2.2. Adicionalmente, o remetente envia uma cópia de $m$ ao checkpoint 
daemon local logo após o término do protocolo de comunicação, concentrando, portanto, o log de mensagens nos daemons do sistema. Por exemplo, o processo $p_{2}$ envia a mensagem $m$ ao processo $p_{4}$ e após o término do protocolo uma cópia de $m$ é enviada ao daemon local.

Como as mensagens possuem tipos variados, é necessário que os daemons do sistema tenham conhecimento, em tempo de compilação, de todos os tipos portas de comunicação definidos em qualquer processo.

Com relação à efetuação do checkpointing, cada processo tolerante a falha envia seu estado relevante ao checkpoint daemon local, encarregado de armazená-lo em disco em um arquivo especificado pelo programador. O estado relevante é enviado em forma de string no padrão XDR e é gravado neste formato no arquivo em questão. Esta forma de gravação do estado relevante permite que o processo continue a execução concorrentemente com a gravação no disco. Na configuração de processos ilustrada pela figura 4.2, podemos observar o checkpointing sendo efetuado pelo processo $p_{5}$.

Para finalizar esta seção destacamos as tarefas atribuídas aos checkpoint daemons durante o processamento normal do sistema:

- Receber uma cópia de cada mensagem enviada pelos processos remetentes locais;

- Receber os estados relevantes destes processos sob requisição explícita dos mesmos;

- Armazenar em disco as mensagens e os estados relevantes provenientes dos processos locais de forma assíncrona em relação ao processamento do sistema.

\subsection{Detecção de falhas e restabelecimento de estado}

Quando uma falha é detectada em um processo $p$, o supervisor, o agente e os checkpoint daemons do sistema devem tratá-la em três etapas:

Nova instanciação. Inicialmente, o agente local instancia em algum nó da rede um novo processo $p$ ' a partir do executável que originou a falha, fornecendo um parâmetro adicional na linha de comando para informá-lo de que deve iniciar a execução restabelecendo o estado.

Leitura do estado relevante. Em seguida, a nova instância $p$ 'lê o estado relevante relativo ao último checkpointing local efetuado pela instância morta $p$, utilizando as rotinas de leitura e gravação mencionadas na seção 1.5.2.

Reprocessamento de mensagens. Nesta última etapa, toda a comunicação realizada entre o processo faltoso $p$ e os demais processos desde o último checkpoint local (efetuado por $p$ ) deve ser retransmitida à nova instância $p$ '.

Vejamos, agora, cada uma destas etapas bem como toda a sincronização de ações entre as componentes do Sampa durante a retomada de execução da nova instância $p_{i}$ ' de um processo faltoso $p_{i}$, conforme ilustrado na figura 4.3. 


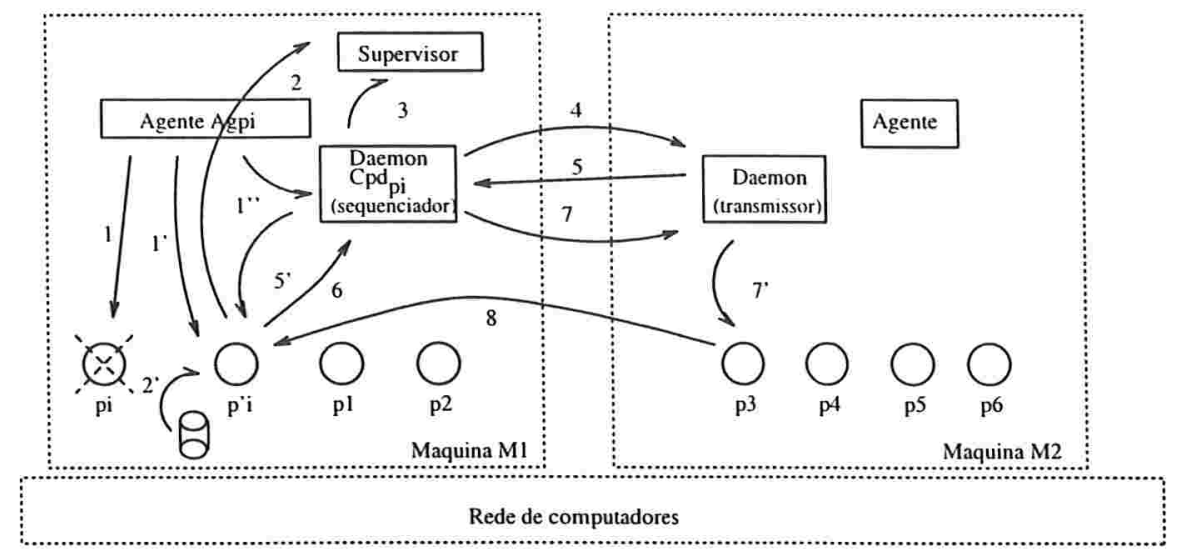

Figura 4.3: Sincronização durante o restabelecimento de execução

1. Sejam $a g p_{i}$ e $c p d p_{i}$ o agente e o daemon responsáveis pelo restabelecimento de estado da nova instância $p_{i}$ '. Inicialmente, ag $p_{i}$ detecta falha no processo $p_{i}$ e notifica o supervisor. Em seguida (1'), ag $p_{i}$ instancia $p_{i}$ 'em algum nó disponível da rede e indiretamente (através do supervisor) avisa $c p d p_{i}\left(1^{\prime \prime}\right)$ sobre este fato.

2. $p_{i}{ }^{\prime}$ informa ao supervisor a relação de bindings disponíveis e também os que utilizará durante sua computação, lê seu estado relevante do disco (2') e entra em estado de reprocessamento de mensagens. Neste momento, $p_{i}$ ' encontrará comandos como send que o farão enviar mensagens duplicadas e receive que o deixarão temporariamente bloqueado até que $c p d p_{i}$ envie as mensagens (ordenadas) recebidas dos daemons transmissores no passo 5. Ao receber a relação dos novos bindings de $p_{i}$ ', o supervisor altera em sua base de dados os bindings originalmente referenciados às portas de $p_{i}$ pela referência às portas de $p_{i}$ '. Em seguida, o supervisor invalida em todos os processos que interagiram com $p_{i}$ os bindings relativos à instância morta, deixando estes processos bloqueados a espera das novas referências relativas à nova instância $p_{i}$ '.

3. $c p d p_{i}$ obtém do supervisor os novos bindings de $p_{i}$ 'e a lista dos daemons transmissores.

4. $c p d p_{i}$ solicita retransmissão de mensagens aos daemons transmissores.

5. Cada daemon transmissor retransmite a $c p d p_{i}$ as mensagens totalmente armazenadas cujo destinatário era $p_{i}$, em qualquer ordem. A medida que estas chegam (5'), $c p d p_{i}$ troca os bindings antigos (de $p_{i}$ ) pelos novos (de $\left.p_{i}{ }^{\prime}\right)$ e as enviam a $p_{i}$ ' em ordem crescente de $r s n$.

6. Após terminar de consumir todas as mensagens, $p_{i}$ 'envia uma notificação a $c p d p_{i}$ informandoo deste fato.

7. $c p d p_{i}$ entra em contado com os daemons transmissores informando-os sobre o término do reprocessamento de mensagens por $p_{i}$ '. Isto significa que as mensagens parcialmente armazenadas nos remetentes (isto é, aquelas mensagens enviadas a $p_{i}$ mas que ainda não tiveram o protocolo de comunicação confiável completado) devem ser enviadas ao novo 
destinatário $p_{i}$ '. A medida que os daemons recebem esta confirmação (7'), eles entram em contato com os processos com referências inválidas para uma atualização das mesmas.

8. Finalmente, as mensagens parcialmente armazenadas são enviadas pelos novos canais de comunicação (agora conectados a $p_{i}{ }^{\prime}$ ) e o restabelecimento de estado está completado.

\subsection{Análise do método de checkpointing}

Há algumas vantagens do método de checkpointing especificado. Vejamos:

- O overhead de tempo de execução para a criação do checkpoint local durante a execução normal dos processos é mínimo, pois basta transferir o estado relevante ao daemon local e este se encarrega de gravá-lo em disco. Além desta transferência para efeito de checkpointing, há apenas um envio adicional de mensagem (do processo ao daemon local);

- O overhead de espaço e a redundância de informação é extremamente reduzido, pois o programador especifica exatamente quais variáveis e estruturas de dados do programa da aplicação pertencerão ao estado relevante. Além disto, o programador pode especificar, por exemplo, a frequência de checkpointing permitindo, assim, modelar as características de tolerância a falha de acordo com as necessidades de desempenho das aplicações;

- Ao contrário de métodos de checkpointing coordenado, apenas a nova instância necessita restabelecer o estado, pois o reprocessamento de mensagens a partir dos logs disponíveis nos daemons do sistema garante a reconstrução correta do estado local da nova instância.

- O gerenciamento dos estados relevantes e dos logs de mensagens por daemons do sistema permite maior disponibilidade e menor instanciação dos processos tolerantes a falha.

Vejamos, agora, algumas desvantagens do método:

- O rastreamento de mensagens causa um overhead de espaço e tempo, especialmente em aplicações que efetuam comunicações frequentes entre seus processos;

- O método requer a participação do programador na definição do estado relevante e da frequência de checkpointing;

- Como o método não prevê meios de armazenar o estado da pilha de execução, as chamadas as rotinas de checkpointing não podem ser efetuadas no interior de procedimentos;

- Aplicações que possuam seu comportamento determinado pelo estado de arquivos ou bancos de dados externos não podem adquirir tolerância a falha usando este mecanismo de checkpointing, pois o estado relevante não contém o estado persistente. 


\section{Capítulo 5}

\section{O protótipo}

Neste capítulo descrevemos a funcionalidade do protótipo que foi implementado para o método de checkpointing descrito no capítulo anterior. Iniciamos com uma pequena introdução da linguagem de programação utilizada: o Concert/C. Em seguida, descrevemos a arquitetura e as interaçōes entre cada componente durante a fase de processamento normal e de restabelecimento de estado de um processo faltoso. Posteriormente, estudamos a configuração e as opções de uso para, nas duas últimas seções, detalhar as informações e estruturas de dados utilizadas em cada componente. Finalizamos o capítulo discutindo possíveis extensões do protótipo.

\subsection{O Concert/C}

O Concert/C [2] é uma linguagem de programação que estende o ANSI C permitindo a programação $\mathrm{C}$ em ambientes distribuídos. Suas principais características são: existência de primitivas para criação e finalização remota de processos; conexão e comunicação entre processos; suporte a RPC (Remote Procedure Call) e envio assíncrono de mensagens.

Qualquer tipo de dado padrão definido no $\mathrm{C}$, incluindo complexas estruturas de dados, podem ser transmitidas de forma remota. Adicionalmente, o Concert/C define um pequeno conjunto de tipos de dados e operadores para dar suporte ao IPC (Inter Process Comunication) e ao gerenciamento de processos.

No Concert/C, os direitos de comunicação são adquiridos através de bindings para portas de comunicação, também denominadas function ports. Bindings podem ser passados entre processos de três formas: no momento da criação remota, utilizando arquivos externos ou através de IPC's. Em nosso protótipo utilizamos frequentemente o segundo método durante as comunicações entre as componentes, de forma que daremos uma breve descrição de suas principais características: o EBF (External Binding Facilities) permite que processos clientes se conectem a servidores em dois passos. Inicialmente, os processos servidores exportam (isto é, gravam) em um arquivo em disco os bindings inicializados de suas portas de comunicação; em seguida, os processos clientes 
importam (ou seja, lêem) os bindings desejados do referido arquivo, estabelecendo, então, um canal de comunicação entre as partes.

A execução de funções remotas (RPC's) é bastante simples: uma vez obtido o binding da função remota, basta executá-la como se a função estivesse definida no código fonte do processo que possui o binding. O envio assíncrono de mensagens é igualmente simples, bastando utilizar o comando send fornecendo como parâmetros o binding da porta de comunicação e o conteúdo da mensagem.

Para finalizar esta breve introdução, concluímos dizendo que o Concert/C foi utilizado no desenvolvimento de nosso protótipo por ser uma linguagem simples que incorpora vários recursos importantes, tornando a programação distribuída relativamente simples. Maiores detalhes sobre aspectos específicos podem ser encontrados no tutorial mencionado no início desta seção.

\subsection{A arquitetura do protótipo}

O protótipo foi implementado em Concert/C para o ambiente operacional Unix (SunOS/Solaris) possuindo todas as características do método de checkpointing a ser adotado no Sampa. Seu principal objetivo é mostrar que o protocolo de rastreamento de mensagens baseado no remetente proposto por Johnson e Zwaenepoel adaptado às necessidades do ambiente Sampa reconstrói corretamente o estado local da nova instância de um processo faltoso.

Antes de apresentar as características e arquitetura, explicaremos porque nosso projeto resultou em um protótipo. Uma das razões é que o Sampa foi proposto para o ambiente DCE, mas durante a fase de implementação, o DCE não se encontrava totalmente instalado e configurado, o que nos levou a utilizar a linguagem Concert/C como substituta.

Outro motivo é que o protótipo pode ser usado apenas para aplicações com a propriedade particular de que cada processo define apenas uma porta de comunicação do tipo string. Adotamos esta restrição com o objetivo de simplificar a implementação dos checkpoint daemons, embora a validação do método de rastreamento de mensagens independe da variedade de portas definidas em cada processo.

Além disto, o estado relevante dos processo é formado apenas por duas variáveis do programa da aplicação: os valores $r s n$ e $s s n$ definidas no método de rastreamento de mensagens proposto por Johnson e Zwaenepoel. Esta restrição foi estabelecida por dois motivos: o conteúdo destas variáveis é fundamental para o funcionamento do protocolo de rastreamento de mensagens em questão e, portanto, devem fazer parte do estado relevante dos processos; em segundo lugar, as rotinas de leitura e gravação do estado relevante no padrão XDR fogem ao escopo deste estudo e estão sendo implementadas em outro trabalho.

Ao contrário do supervisor proposto na arquitetura Sampa, que mantém uma base de dados detalhada sobre a configuração do sistema (mas que ainda se encontra em desenvolvimento), nosso supervisor implementa apenas a parte de serviços de gerenciamento de configuração do supervisor original. No entanto, o denominaremos supervisor no restante deste texto tendo-se em mente esta distinção. 
A última particularidade é relativa a uma pequena mudança introduzida na sincronização de ações durante a execução da nova instância, onde optamos por utilizar alguns timeouts ao invés de implementar alguns dos passos definidos na seção 4.3. Esta particularidade será discutida em detalhes na seção 5.3.3.

É importante mencionar que, embora estas restrições estejam presentes, nenhuma delas influi no método de rastreamento de mensagens implementado. $\mathrm{Na}$ verdade, elas foram impostas durante a fase de projeto para que fosse possível implementá-lo no período de tempo disponível.

A arquitetura do protótipo consiste de quatro componentes: o supervisor, os checkpoint daemons, o gerenciador de processos e os processos de aplicação. Usando como base a figura 5.1 , faremos uma apresentação detalhada de cada uma delas.

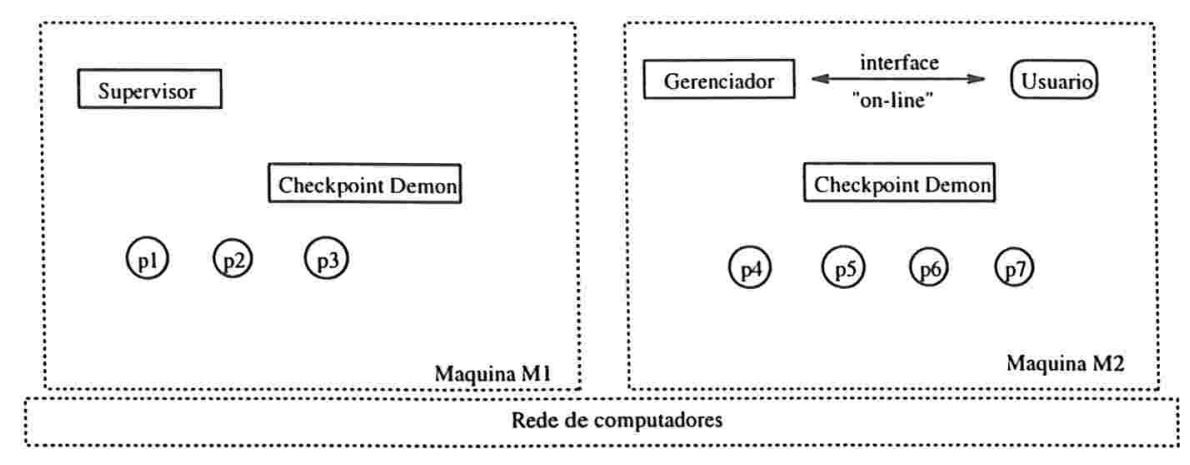

Figura 5.1: Arquitetura do protótipo

A função principal do supervisor é manter informações sobre a configuração dos processos de aplicação e daemons que executam na rede de máquinas $M_{i}$. Em particular, são atribuições do supervisor manter um conjunto de informações sobre cada um dos processos tolerantes a falha, tais como, bindings das portas de comunicação, nome das máquinas em que executam e estado atual de execução (em execução normal, processo em estado faltoso ou nova instância em retomada de execução).

Cada máquina $M_{i}$ contém uma componente do sistema denominada checkpoint daemon, responsável por armazenar os logs de mensagens e o estado relevante dos processos locais. Outra tarefa importante consiste em restabelecer a execução de processos faltosos através do reprocessamento de mensagens dos logs locais.

O gerenciador de processos é uma componente adicional introduzida no protótipo para possibilitar a construção de aplicações distribuídas, testar diversos padrões de interação e simular falhas em processos. De uma forma geral, o gerenciador é o meio através do qual o usuário interage com todas as componentes, desde o supervisor do sistema até os processos de aplicação, utilizando para tanto um conjunto de comandos predefinidos.

A idéia central do gerenciador é simular algumas das tarefas originalmente atribuídas aos agentes e ao supervisor da arquitetura Sampa, tais como, estabelecer conexões entre processos, (simular) a detecção de falhas e controlar a interação entre as componentes durante o restabelecimento de estado de uma nova instância. 
Os processos de aplicação (ilustrados por $p_{j}$ ) representam protótipos de processos reais no sentido de que seu processamento local e comportamento em termos de comunicações são determinados pelo usuário através de comandos do gerenciador. Por exemplo, o usuário pode desejar que um dado processo se comporte como um servidor FIFO, como uma componente em uma estrutura de anel, ou um processo mestre em uma configuração mestre-escravo.

\subsection{Interface e interação entre as componentes}

Nesta seção descrevemos a interface de cada componente, utilizando a sintaxe para definição de estruturas de dados da linguagem C. Posteriormente, analisamos a interação durante o processamento normal e o restabelecimento de estado.

\subsubsection{Interface das componentes}

A interface do supervisor é constituída exclusivamente de um conjunto de portas de comunicação que disponibilizam serviços às demais componentes. Dentre estes serviços temos o cadastramento de processos e daemons, informação sobre uma ou mais componentes cadastradas e uma completa relação de bindings. O acesso a estas portas é feita pelo usuário através do gerenciador, utilizando-se um conjunto de comandos preestabelecidos. Vejamos, em detalhes, cada destas portas de comunicação e o tipo de serviço disponível.

register_b_port. Registro de processos de aplicação

A primeira tarefa realizada por qualquer processo após iniciar a execução é exportar o binding de sua porta de comunicação. Isto é feito através de uma chamada RPC à porta register_b_port.

Por exemplo, após ser criado, o processo $p_{1}$ faz automaticamente esta chamada RPC, fornecendo como parâmetro seu nome $\left(p_{1}\right)$, a máquina em que executa $\left(m_{1}\right)$, o binding de sua receiveport e seu estado de execução, definido como login (ativo no sistema) ou logout (inativo).

Conforme mencionado no início deste capítulo, cada processo registra apenas um binding relativo a uma porta do tipo string. Uma das generalizações do protótipo seria, então, permitir o registro de diversos bindings para diferentes tipos de mensagens.

inform_port e get_address. Informação sobre processos de aplicação registrados

É importante que qualquer componente do sistema tenha acesso as informações relativas a um dado processo de aplicação no supervisor. Isto pode ser feito através de duas portas de comunicação: inform_port e get_address. A primeira retorna informações a respeito do estado de execução do processo (login ou logout), a hora em que o registrado foi realizado no supervisor e a máquina em que executa; a segunda retorna o binding da receiveport do processo fornecido como parâmetro, e deve ser utilizada quando o usuário deseja conectar dois processos para um posterior envio assíncrono de mensagens. 
register_cpd. Registro de checkpoint daemons

Os checkpoint daemons devem efetuar um registro no supervisor para permitir que os processos de aplicação possam conectar o daemon local logo após iniciar a execução. Outra utilidade deste registro é disponibilizar o binding da porta de comunicação (denominada porta de log no restante deste texto) a qualquer componente do sistema durante a fase restabelecimento de estado. Para efetuar o registro, cada daemon efetua um RPC em register_cpd fornecendo como parâmetros a sua identificação, a máquina em que executa e o binding de sua porta de log.

get_cpd_log_receiveport. Obtenção de porta de log de checkpoint daemon cadastrado Para obter o binding da porta de log de um dado checkpoint daemon local, o processo de aplicação deve utilizar a chamada à função remota get_cpd_log_receiveport, fornecendo como parâmetro a máquina em que executa.

Este serviço do supervisor permite a conexão entre os processos e o daemon local descrito anteriormente. Outra utilidade é permitir que o usuário obtenha (através do gerenciador) o binding da porta de log de um checkpoint daemon em particular para solicitar a exibição do log de mensagens.

get_all_processes e get_all_cpds. Relação de processos e daemons cadastrados

O supervisor possui mais duas portas importantes: get_all_processes e get_all_cpds, destinadas a retornar o binding de cada processo de aplicação e checkpoint daemon cadastrados no supervisor. Estas portas são utilizadas pelo gerenciador durante o restabelecimento de estado para contatar todas as componentes do sistema, objetivando a reconfiguração do ambiente.

leave_protocol. Armazena dados relativos ao processo faltoso e a nova instância

A função remota leave_protocol armazena o nome e máquina em que o processo faltoso executava e os mesmos dados relativos à instância que o substituirá.

Ela é utilizada pelos checkpoint daemons e pelos processos de aplicação para alterar referências aos bindings inválidos (relativos à instância faltosa) pelos novos bindings, possibilitando a atualização do log de mensagens e a conexão ao novo canal de comunicação.

Descrevemos, agora, a interface dos checkpoint daemons, do gerenciador e dos processos de aplicação.

Daemons: porta de log. A interface dos checkpoint daemons é única: apenas a porta de log é disponível a qualquer outra componente. Uma vez instanciado, todo checkpoint daemon cadastra o nome, a máquina e o binding de sua porta de log utilizando a função remota registra_cpd do supervisor. Para que uma dada componente do sistema obtenha o binding da porta de log de um checkpoint daemon, basta utilizar a função remota get_cpd_log_receiveport.

Durante o restabelecimento de estado, os daemons recebem do gerenciador comandos na porta de log especificando qual deles será o responsável pela transmissão de mensagens à nova instância (denominado sequenciador) e quais daemons (denominados transmissores) deverão transmitir as mensagens de seu log ao sequenciador. A divisão de tarefas entre os 
daemons é descrita em detalhes mais adiante, mas, de uma forma geral, o sequenciador é o daemon local à máquina em que a nova instância executa; os demais daemons serão os transmissores.

Gerenciador: linha de comando. A interface do gerenciador é utilizada diretamente pelo usuário na forma de um conjunto de comandos predefinidos. É através dela que o usuário tem acesso a qualquer porta de comunicação do sistema.

Processos de aplicação: receiveport. A única porta de comunicação que os processos de aplicação disponibilizam é a receiveport, denominada message_receiveport. Para que uma componente do sistema tenha acesso à receiveport de um processo cadastrado, é necessário utilizar a função remota get_address, descrita no conjunto de portas do supervisor. É na message_receiveport que um processo recebe mensagens, comandos do gerenciador e mensagens transmitidas pelo daemon sequenciador durante o restabelecimento de estado.

\subsubsection{Interação entre componentes no processamento normal}

Nesta seção descrevemos, sem detalhar os comandos do gerenciador, como o usuário interage com as componentes do sistema. Partimos do princípio de que já existe uma configuração inicial formada por duas máquinas, um supervisor, um gerenciador, dois daemons e cinco processos, conforme figura 5.2 .

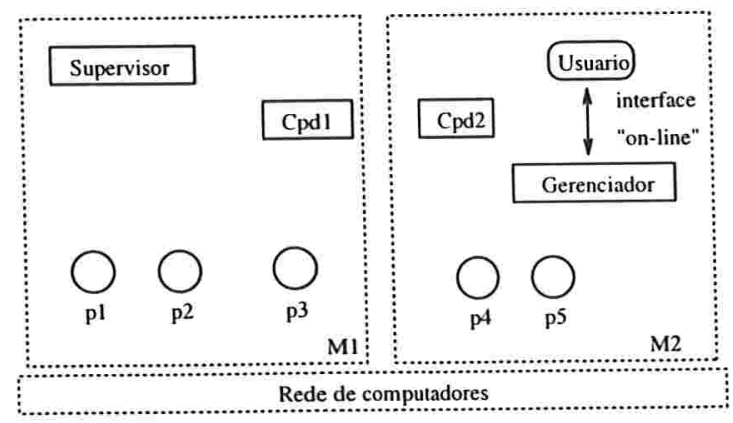

Figura 5.2: Interação entre componentes no processamento normal

Através do gerenciador o usuário pode realizar as seguintes tarefas:

- Conectar dois processos;

- Enviar mensagens assíncronas entre processos previamente conectados;

- Pedir informações sobre todos os processos cadastrados no supervisor;

- Pedir aos daemons a exibição do conteúdo dos logs de mensagens;

- Simular falha em um processo. 
Antes de iniciarmos a explanação, é necessário esclarecer que o gerenciador só pode interagir (isto é, enviar comandos) com alguma componente se tiver o binding de sua receiveport. Ao iniciar a execução, o gerenciador obtém automaticamente os bindings de todas as portas de comunicação do supervisor, possibilitando a comunicação com ele à medida que for necessário. No entanto, os bindings dos daemons do sistema e dos processo de aplicação são obtidos sob requisição explícita do usuário. Por hora partimos do princípio de que os bindings das componentes com as quais o usuário deseja interagir estão disponíveis, deixando os detalhes de como obtê-los para a seção 5.5 onde descrevemos os comandos do gerenciador.

Para conectar dois processos de aplicação, o usuário deve informar ao gerenciador o nome e máquina de cada um deles. Por exemplo, para conectar os processos ( $\left.p_{1}: m_{1}\right)$, isto é, o processo denominado $p_{1}$ que executa na máquina $m_{1}$, com o processo $\left(p_{4}: m_{2}\right)$, é necessário informar ao gerenciador estes dois pares de parâmetros.

Para enviar mensagens do processo $\left(p_{1}: m_{1}\right)$ para $\left(p_{4}: m_{2}\right)$ basta fornecer o conteúdo da mensagem ao gerenciador. Toda vez que uma mensagem é enviada, os dois processos envolvidos seguem o protocolo de comunicação confiável descrito na seção 3.2.2 e uma cópia da mensagem é enviada automaticamente ao daemon local à máquina em que o remetente executa.

Antes de descrevermos a próxima característica, convém fazer uma observação. A conexão entre dois processos estabelece um canal de comunicação unidirecional, isto é, ao conectar os processos acima, o usuário pode enviar mensagens de $p_{1}$ para $p_{4}$, mas não pode fazer um envio de $p_{4}$ a $p_{1}$. Para que esta extensão seja possível, é necessário conectá-los no sentido contrário.

Outra opção disponível durante o processamento normal é solicitar a exibição de todos os processos cadastradas no supervisor. Por exemplo, se o usuário deseja que o processo $p_{1}$ informe a relação de todos os processos (ou um em específico) cadastrados, ele deve fazer o pedido ao gerenciador e o resultado será exibido no terminal associado a $p_{1}$.

Também é possível requisitar aos daemons cadastrados no supervisor a exibição do conteúdo dos logs de mensagens. Para tanto, o usuário deve conectar o gerenciador ao daemon desejado e solicitar a exibição.

Uma última característica importante é a possibilidade do usuário simular falha em um processo de aplicação. Isto é feito informando-se ao gerenciador a identificação do processo no qual faremos a simulação. Por exemplo, para simular a morte do processo $p_{1}$, o usuário deve fornecer ao gerenciador os identificadores $p_{1}$ e $m_{1}$.

\subsubsection{Interação entre componentes no processamento pós falha}

A seguir descrevemos a interação entre as componentes do sistema desde a simulação de falha até o completo restabelecimento de estado da nova instância, sem entrar em detalhes sobre os comandos do gerenciador utilizados para este fim. As etapas envolvidas nesta fase são semelhantes aos passos gerais envolvidos no restabelecimento a ser adotado no Sampa, descritos na seção 4.3, de forma que utilizamos, basicamente, a mesma figura ilustrada naquela seção, substituindo os agentes locais por um único gerenciador de processos, conforme ilustrado na 
figura 5.3.

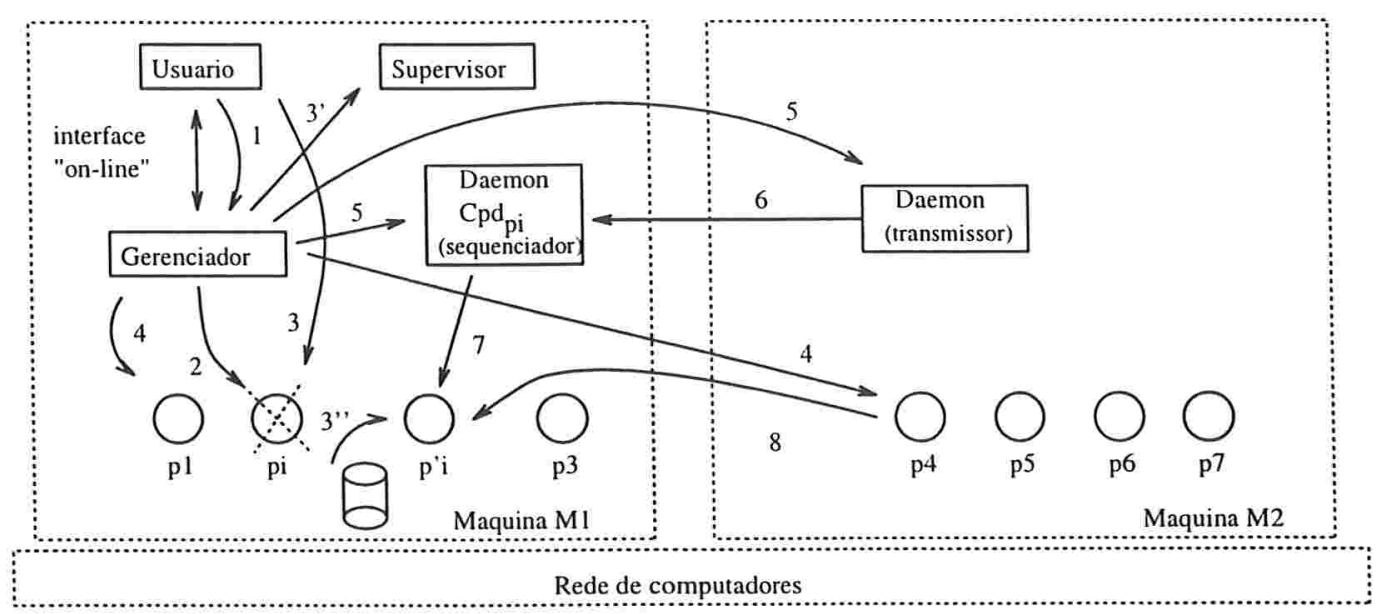

Figura 5.3: Sincronização durante o restabelecimento de execução

Seja $\left(p_{i}^{\prime}: m_{1}\right)$ a nova instância que substituirá o processo faltoso $\left(p_{i}: m_{1}\right)$, onde $p_{i}$ 'é o nome da nova instância e $m_{1}$ é a máquina em que ela executará.

1. Inicialmente, o usuário informa ao gerenciador a intenção de simular falha em $\left(p_{i}: m_{1}\right)$.

2. O gerenciador processa o pedido, finalizando a execução da instância $\left(p_{i}: m_{1}\right)$

3. Em seguida, o usuário cria a nova instância $\left(p_{i}{ }^{\prime}: m_{1}\right)$ e, em paralelo (3'), o gerenciador informa o supervisor sobre a falha, utilizando o RPC leave_protocol. Concorrentemente (3") , a nova instância lê o estado relevante relativo ao último checkpoint local permanente.

4. O gerenciador contata todos os processos registrados com login no supervisor, requisitando a atualização das tabelas de maiores valores $r s n$ e $s s n$, e a validação do binding relativo à porta de comunicação da nova instância. Em nossa figura, representamos a conexão do gerenciador a dois processos, apenas, para não sobrecarregá-la.

Mais especificamente, o gerenciador solicita ao supervisor uma lista contendo todos os processos registrados com login. Ao recebê-la, ele contata cada um deles e envia um comando solicitando a atualização de tabelas e bindings. Ao recebê-lo, cada processo utiliza o RPC leave_protocol para obter o nome, a máquina e o binding da porta de comunicação da nova instância, possivelmente confirmando uma hipótese relativa a morte de um determinado processo. Isto mesmo, um processo $p$ pode desconfiar que outro processo $q$ sofreu uma falha se a confirmação contendo o valor $r s n$ relativo a mensagem enviada a $q$ não chegar em um dado intervalo de tempo. Esta desconfiança só se transforma em certeza após receber a confirmação do supervisor.

5. Em seguida, o gerenciador contata o supervisor para obter uma lista de todos os daemons do sistema e, baseado na máquina em que a nova instância executa, o gerenciador define o daemon sequenciador e os transmissores, enviando uma notificação a cada um deles. 
O restante do restabelecimento de estado envolve os daemons e todos os processos que se comunicaram com a instância morta desde seu último checkpointing. A participação destes últimos é necessária, para completar o protocolo de comunicação confiável à medida que a nova instância envia mensagens duplicadas.

6. Como os daemons possuem uma única porta para receber os comandos do gerenciador, para armazenar as cópias das mensagens enviadas por processos locais e para receber mensagens dos daemons transmissores, tornou-se necessário utilizar um timeout para que as notificações do gerenciador não intercalem com as mensagens enviadas pelos daemons transmissores. Uma alternativa para isto é criar portas específicas para estes três tipos de mensagens.

Após expirado o timeout, os daemons efetuam as seguintes tarefas, nesta ordem:

- Consultam o supervisor para obter o nome, a máquina e o binding da porta de comunicação do processo faltoso e da instância substituta;

- Obtêm os valores $s s n_{u}$ e $r s n_{u}$ relativo ao último checkpointing efetuado pela instância morta. Estes dados são usados da seguinte forma: o daemon sequenciador deverá colocar em sua bag ${ }^{1}$ apenas as mensagens com rsn maior que $r s n_{u}$, e as mensagens com rsn menor ou igual devem ser removidos do log local; os daemons transmissores deverão enviar ao sequenciador apenas as mensagens com ssn maior que o $s s n_{u}$, e as mensagens com ssn menor ou igual devem ser removidas do log;

- Finalmente, ocorre a transmissão de mensagens ao daemon sequenciador. Em um primeiro momento, os daemons transmissores obtêm do supervisor o binding da porta de $\log$ do daemon sequenciador para, em seguida, enviar as mensagens que possuam a instância faltosa como processo receptor.

Convém fazer uma observação em relação a esta última etapa. O início e término da transmissão de mensagens é baseada em um timeout, fixado em 20 segundos para o conjunto de exemplos e padrões de comunicação analisados. Uma solução mais adequada para isto é o uso de delimitadores nas mensagens transmitidas ao daemon sequenciador. Por exemplo, cada daemon transmissor inicia o envio remetendo, inicialmente, uma mensagem contendo o delimitador InicioDaTrasmissão. Após enviar a última mensagem, a transmissão é finalizada com o delimitador FimDaTrasmissão. Com isto, o daemon sequenciador inicia o envio das mensagens a nova instância após receber um número de delimitadores de finalização de transmissão igual ao número de delimitadores de início de transmissão.

7. O daemon sequenciador ordena as mensagens totalmente armazenadas recebidas dos transmissores em ordem crescente de $r s n$, e as envia à nova instância $p_{i}$ '. A medida que ela as consome, o protocolo de comunicação confiável é executado entre os processos envolvidos, e possíveis mensagens duplicadas enviadas por $p_{i}$ 'são rejeitadas;

\footnotetext{
${ }^{1}$ Uma bag é uma lista ligada usada para armazenar temporariamente as mensagens enviadas pelos daemons transmissores. O daemon sequenciador enviará à nova instância todas as mensagens contidas em sua bag, em ordem crescente de rsn.
} 
8. Finalmente, as mensagens parcialmente armazenadas são remetidas à nova instância, finalizando o restabelecimento de estado.

Neste passo fizemos uma pequena modificação em relação ao que será adotado no Sampa. Na seção 4.3 especificamos que após consumir as mensagens totalmente armazenadas (isto é, aquelas enviadas pelo daemon sequenciador), a nova instância avisaria o daemon local, que notificaria os demais daemons do sistema que, por sua vez, informariam todos os processos locais para enviar possíveis mensagens parcialmente armazenadas.

Implementamos algo um pouco mais simples, mas trivialmente adaptável às definições originais. Ao invés das notificações, determinamos que cada processo de aplicação aguarde um certo tempo ${ }^{2}$ antes de enviar possíveis mensagens parcialmente armazenadas à nova instância.

\subsection{Configuração e uso do protótipo}

A seguir estudamos aspectos relacionados a instalação do protótipo e discutimos uma opção de uso importante. Para simplificar a explicação, usaremos o termo xterm para designar uma janela do ambiente XWindows. Cada xterm constitui uma seção de terminal independente do ambiente operacional Unix, permitindo ao usuário executar qualquer programa, utilitário ou comando Unix.

Construiremos a configuração inicial do protótipo ilustrado na figura 5.4, especificando como cada componente deve ser criada. Este exemplo ilustra um sistema formado por cinco máquinas $m_{1}, m_{2}, \ldots, m_{5}$, um supervisor, cinco daemons $c p d_{1}, c p d_{2}, \ldots, c p d_{5}$, um gerenciador e nove processos, nomeados $p_{1}, p_{2}, \ldots, p_{9}$.

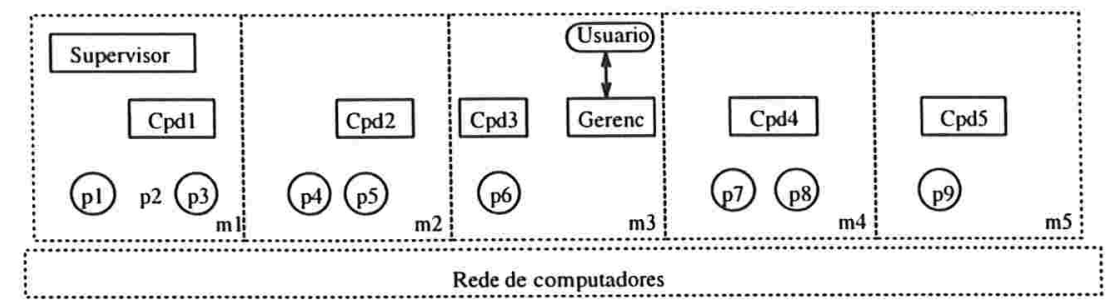

Figura 5.4: Configuração do protótipo

O protótipo é formado por quatro programas executáveis: sv representando o supervisor, cpd usado para instanciar daemons, ap representa os processos de aplicação e o gd instancia gerenciadores de processos.

A primeira componente do protótipo a ser criada é o supervisor do sistema. Isto é feito digitando-se sv na linha de comando do Unix:

[m1:/home/prototipo] > sv

\footnotetext{
${ }^{2}$ Para todos os exemplos e padrões de comunicação analisados, verificamos que 30 segundos é suficiente, valor este obtido em função dos tempos estimados nos passos 6 e 7 .
} 
[sv:m1] > Supervisor iniciado na máquina $\mathrm{m} 1 \ldots$

[sv:m1] > Aguardando requisição de serviços...

Após a criação, o supervisor informa ao usuário que está a espera de requisição de serviços das demais componentes.

Em seguida, os checkpoint daemon devem ser instanciados. Se desejarmos que todas as máquinas sejam equipadas com nossos mecanismos de checkpointing, é necessário criar um daemon em cada uma delas. O exemplo a seguir instancia o checkpoint daemon $c p d_{1}$ na máquina $m_{1}$.

[m1:/home/prototipo] > cpd cpd1

[cpd1:m1] > Registrando ( cpd1: $\mathrm{m} 1$ ) no supervisor.

[cpd1:m1] > Iniciando rastreamento de mensagens.

Ao instanciá-lo, o usuário é informado sobre o registro junto ao supervisor e, em seguida, o daemon inicia o rastreamento de mensagens enviadas por processos locais. $\mathrm{O}$ par $\left(c p d_{1}, m_{1}\right)$ o identifica no conjunto de daemons do sistema.

As próximas componentes a iniciar a execução são os processos de aplicação. Para instanciar o processo $p_{1}$ na máquina $m_{1}$, basta fazer isto:

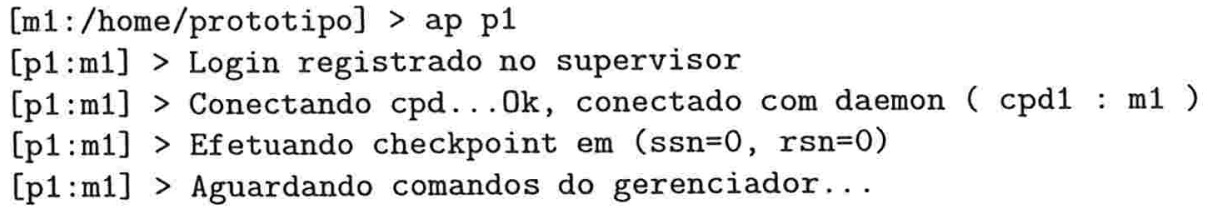

As notificações indicam que o processo $\left(p_{1}: m_{1}\right)$ registrou login no supervisor, conectou ao checkpoint daemon local, efetuou um checkpointing para, finalmente, entrar em estado de recepção de comandos do gerenciador.

Estes passos permitem criar uma configuração aleatória de processos. Para possibilitar a interação entre elas, é necessário criar um ou mais instâncias do gerenciador de processos, desta forma:

[m2:/home/prototipo] > gd

[ger:m2] > Faça a opção [p] inicialmente. Use [h] para ajuda.

[ger:m2] > Gerenciador aguardando comandos do usuário...

[ger:m2] >

Neste momento, o usuário pode construir exemplos de execução arbitrários, bastando interagir com o gerenciador usando o conjunto de comandos descritos na próxima seção. No entanto, esta instanciação de componentes cria uma situação determinística, onde os comandos do gerenciador são executados sequencialmente. Por exemplo, se o usuário solicitar os comandos $a$, $b$ e $c$ nesta ordem, eles serão repassados às respectivas componentes na mesma sequência e, possivelmente, executados nesta mesma ordem, dependendo do tráfego na rede. Para simular o indeterminismo, isto é, uma situação em que os comandos acima sejam executados em uma ordem arbitrária, basta fornecer o parâmetro adicional /ind na linha de comando ao criar os processos de aplicação, conforme exemplificado a seguir na criação do processo $\left(p_{1}: m_{1}\right)$. 
[m1:/home/prototipo] > ap p1/ind

$[\mathrm{p} 1: \mathrm{m} 1]>$ Versão Indeterministica...

[p1:m1] > Login registrado no supervisor

[p1:m1] > Conectando cpd...0k, conectado com daemon ( cpd1: $\mathrm{m} 1$ )

$[\mathrm{p} 1: \mathrm{m} 1]>$ Aguardando comandos do gerenciador...

A idéia do indeterminismo é simular um processamento interno em cada processo de aplicação que consome certo tempo de computação, afetando diretamente os eventos de envio de mensagens. Isto causa uma configuração de eventos arbitrariamente diferente da ordem que o usuário determina ao gerenciador.

\subsection{Comandos do gerenciador de processos}

Nesta seção apresentamos os comandos do gerenciador disponíveis ao usuário para interagir com qualquer componente do protótipo. A idéia do gerenciador é receber comandos e enviá-los às componentes com as quais o usuário deseja se comunicar. Por exemplo, se usuário solicita ao processo $p$ a execução de um comando $x$, então $p$ recebe a requisição do gerenciador, a executa e exibe o resultado em seu xterm.

Vejamos, então, uma descrição detalhada de todos os comandos, utilizando, como exemplo, um sistema formado por dois processos $p$ e $q$, dois daemons, $c p d_{1}$ e $c p d_{2}$, o supervisor e um gerenciador, ilustrado na figura 5.5.

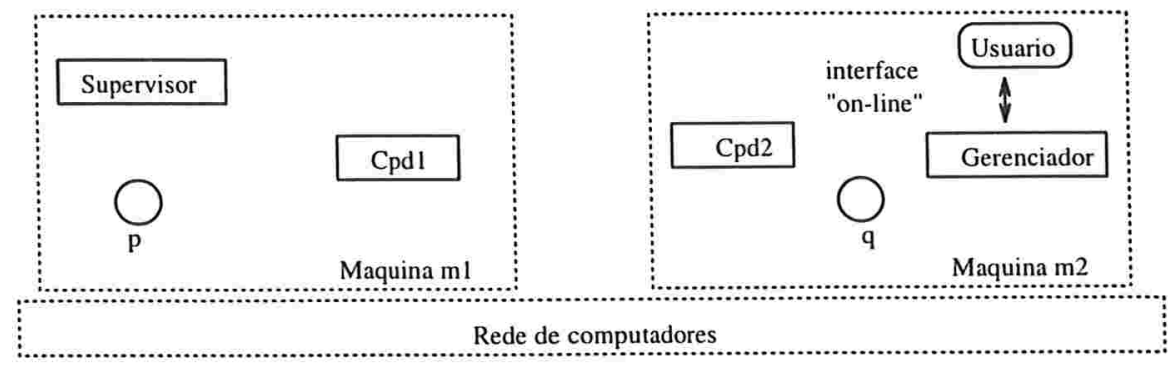

Figura 5.5: Exemplo ilustrativo dos comandos do gerenciador

Ajuda. A qualquer momento é possível obter uma relação completa de todos os comandos do gerenciador através da opção $h$.

Conexão a processo. Antes de enviar comandos a qualquer processo de aplicação, é necessário conectar o gerenciador ao processo com o qual o usuário deseja interagir. Isto é feito através da opção p.

Ao digitar $\mathrm{p}$ na linha de comando, o gerenciador solicita o nome e máquina do processo a ser conectado. Por exemplo, para conectar o gerenciador ao processo ( $\left.\mathrm{p}: m_{1}\right)$, basta proceder da seguinte forma: 


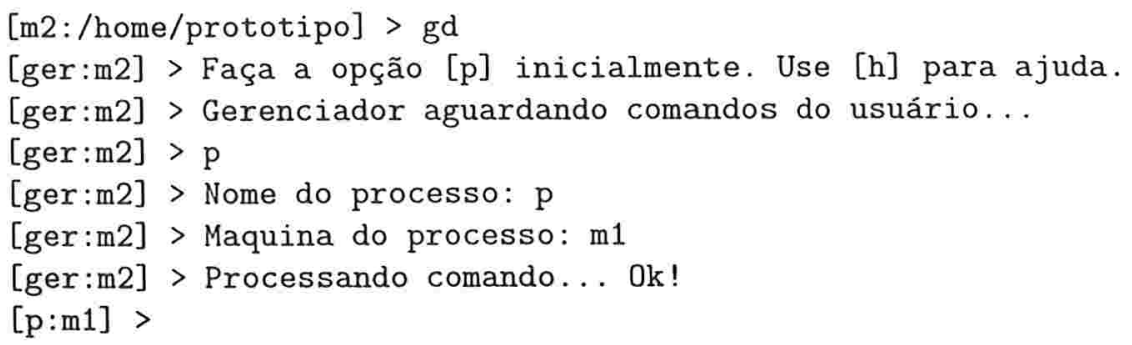

Observe que a linha de comando do gerenciador sofre uma pequena mudança, passando a representar o nome do processo atualmente conectado. Esta conexão permanece válida até que o usuário conecte o gerenciador a outro processo.

Os demais comandos partem do princípio de que o usuário conectou o gerenciador ao processo com o qual o deseja iteragir.

Registra. O comando registra, representado pela opção $r$, é utilizado para solicitar ao processo conectado o registro no supervisor. Um registro de login implica a participação do processo nos mecanismos de checkpointing, isto é, seu estado de execução é monitorado pelo supervisor e pelo gerenciador. Processos registrados com logout não são tolerantes a falha pois um logout indica o término da participação no mecanismo de checkpointing.

Ao iniciar a execução, todo processo registra login automaticamente. Ao digitar $r$ na linha de comando do gerenciador, o estado de execução do processo passa a ser logout. Digitando-se novamente $r$, o estado de execução volta a login.

Por exemplo, para registrar um logout em $p$, o usuário deve interagir com o gerenciador desta forma:

$[\mathrm{p}: \mathrm{m} 1]>\mathrm{r}$

$[\mathrm{p}: \mathrm{m} 1]>$ Processando comando... Ok !

O resultado da operação é assim exibido no xterm de $p$ :

[p:m1] > Logout registrado no supervisor

Conecta. O comando c conecta $p$ a outro processo de aplicação. Ao digitar c na linha de comando, é solicitado ao usuário o nome e máquina do processo ao qual $p$ deve ser conectado, conforme podemos observar no exemplo abaixo.

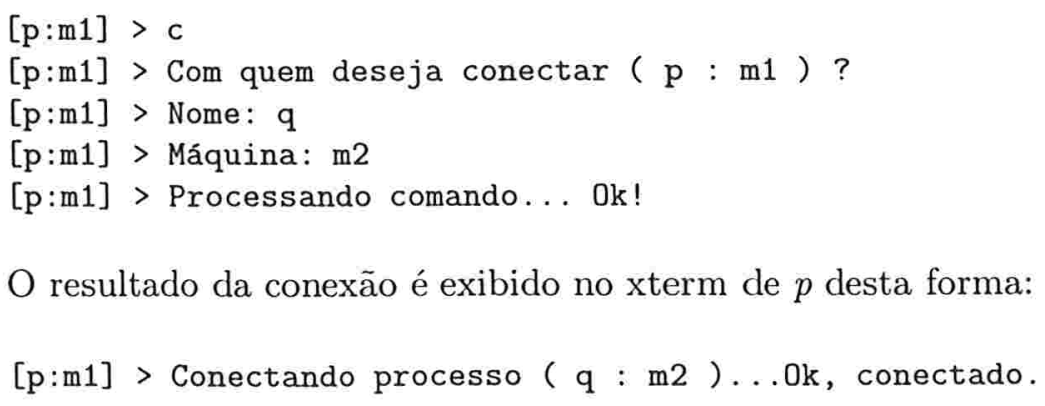

O resultado da conexão é exibido no xterm de $p$ desta forma:

[p:m1] > Conectando processo ( $\mathrm{q}: \mathrm{m} 2) \ldots 0 \mathrm{k}$, conectado. 
Send. O comando send permite a $p$ enviar uma mensagem $m$ ao processo $q$ previamente conectado. Ao utilizar a opção s, o gerenciador solicita ao usuário o conteúdo da mensagem, conforme ilustrado abaixo:

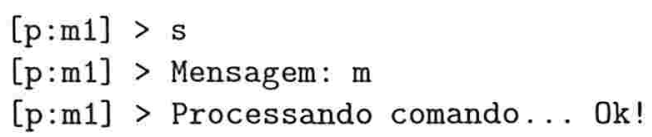

Em um envio de mensagem, três processos estão envolvidos: o remetente e o receptor que seguirão o protocolo de comunicação confiável; e o daemon local à máquina em que o processo remetente executa, que receberá uma cópia da mensagem enviada.

A notificação sobre o envio de $m$ ao processo $q$ é visto no xterm de $p$ desta forma:

$[\mathrm{p}: \mathrm{m} 1]>+++$ enviado $\ll \mathrm{m} \gg$ a $(\mathrm{q}: \mathrm{m} 2)$ sob $\mathrm{ssn}=1$

A recepção da mensagem por $q$ é verificada desta forma:

[q:m2] $>---$ Chegou $\ll m ~ \gg>$ de $(p: m 1), s s n=1$, retornando $r s n=1$

Note que $p$ enviou o valor $s s n$ relativo a mensagem $m$, conforme requisições do protocolo de comunicação confiável. Em seguida, o receptor $q$ informa ao usuário sobre o recebimento da mensagem e retorna o valor $r s n$ atribuído a $m$, finalizando o protocolo de comunicação entre os dois processos. Ao receber o valor $r s n$, o remetente $p$ envia uma cópia de $m$ ao daemon local, conforme evidenciamos a seguir:

[p:m1] $>+++$ enviado copia de $\ll m \gg$ a ( $\mathrm{mpd} 1: \mathrm{m} 1)$ sob (ssn=1, rsn=1)

O daemon local à máquina $m_{1}$ notifica o usuário sobre o recebimento da cópia da mensagem.

[cpd1:m1] $>\mathrm{msg} \ll \mathrm{m} \gg$ destinada a ( $\mathrm{q}: \mathrm{m} 2)$ incluída no $\log (\mathrm{ssn}=1, \mathrm{rsn}=1)$

Checkpointing. É possível solicitar a um processo a realização de checkpointing em qualquer momento de sua execução. Para tanto, o usuário deve solicitar o pedido ao gerenciador através da opção $\mathrm{k}$. Por exemplo, para efetuar um checkpointing no processo $p$, o usuário deve proceder da seguinte forma:

$[\mathrm{p}: \mathrm{m} 1]>\mathrm{k}$

[p:m1] $>$ Enviando pedido de checkpointing a ( $\mathrm{p}: \mathrm{m} 1$ )

[p:m1] > Processando comando... Ok!

O resultado da solicitação de checkpointing é assim exibido no xterm de $p$ :

$[p: m 1]>$ Efetuando checkpointing em ( $s s n=1: r s n=0) \ldots$

Ao efetuar o checkpointing, o processo grava em disco o valor das duas variáveis (ssn e $r s n)$ representantes do estado relevante. 
Informa. Esta opção é utilizada para requisitar a $p$ uma relação de todos os processos registrados no supervisor. Ao digitar i na linha de comando, o gerenciador solicita ao usuário o nome do processo a ser pesquisado, ou todos para exibir informações sobre todos os processos registrados. Por exemplo, a relação de todos os processos é obtida desta forma:

[p:m1] > Nome da aplicação (/todos): todos

[p:m1] > Processando comando... Ok!

O resultado é assim exibido no xterm de $p$.

[p:m1] > Referências a $\ll$ todos $\gg$ encontradas:

Aplicação ( $p$ : m1 ), efetuou login em date: Mon Feb 24 21:15:09 1997

Aplicação ( q : m2 ), efetuou login em date: Mon Feb 24 21:17:42 1997

Mata. O comando m é utilizado para simular falha em um processo de aplicação. Por exemplo, para simular falha em $p$, o usuário deve proceder desta forma:

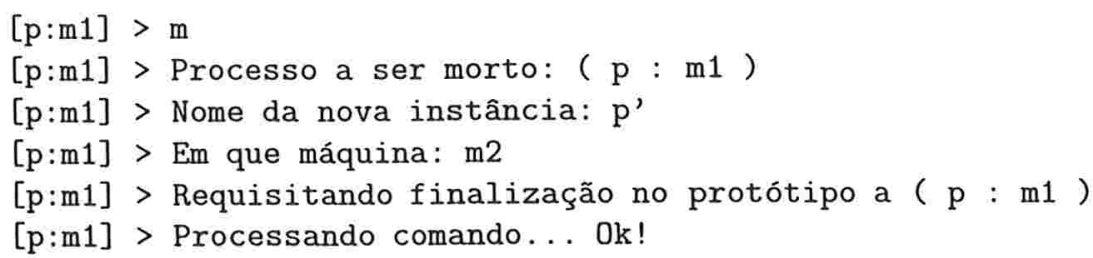

Após o usuário ser informado sobre qual processo será morto pelo gerenciador, é solicitado o nome e máquina da nova instância. A solicitação de morte em $p$ provoca um registro de logout e o retorno à linha de comando do Unix, como podemos observar abaixo.

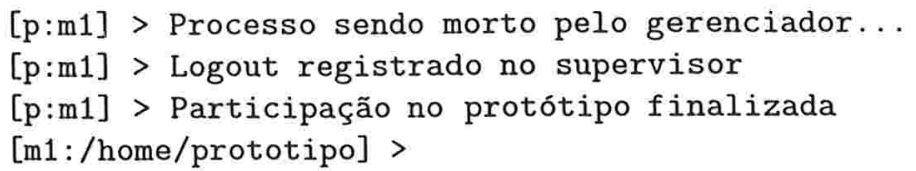

Abandona. A opção a solicita a finalização no sistema ao processo conectado ao gerenciador. Por exemplo, para finalizar a execução de $q$ em nossos mecanismos de checkpointing, basta interagir com o gerenciador desta forma (supondo que o gerenciador esteja conectado a $q$ ):

$[\mathrm{q}: \mathrm{m} 2]>\mathrm{a}$

[q:m2] > Processando comando... Ok!

e o resultado da solicitação exibido no xterm de $q$ é o seguinte:

[q:m2] > Logout registrado no supervisor

[q:m2] > Participação no protótipo finalizada

[m2:/home/prototipo] >

Conexão a checkpoint daemon. A opção n conecta o gerenciador ao daemon requisitado pelo usuário. Por exemplo, para conectar o gerenciador ao daemon ( $\left.c p d_{1}: m_{1}\right)$, é necessário fazer isto: 
$[\mathrm{p}: \mathrm{m} 1]>\mathrm{n}$

[p:m1] > Nome do daemon do sistema: cpd1

$[\mathrm{p}: \mathrm{m} 1]>$ Máquina em que o daemon executa: $\mathrm{m} 1$

$[\mathrm{p}: \mathrm{m} 1]>$ Processando comando... 0k!

$[\mathrm{cpd} 1: \mathrm{m} 1]>$

Observe que esta opção fez a linha de comando do gerenciador refletir o nome e máquina da nova componente conectada.

Visualização do log. O comando d requisita ao checkpoint daemon conectado ao gerenciador a relação de todas as mensagens armazenadas em seu log.

Por exemplo, para exibir o conteúdo do log de mensagens do daemon conectado ao gerenciador, o usuário deve fazer o seguinte:

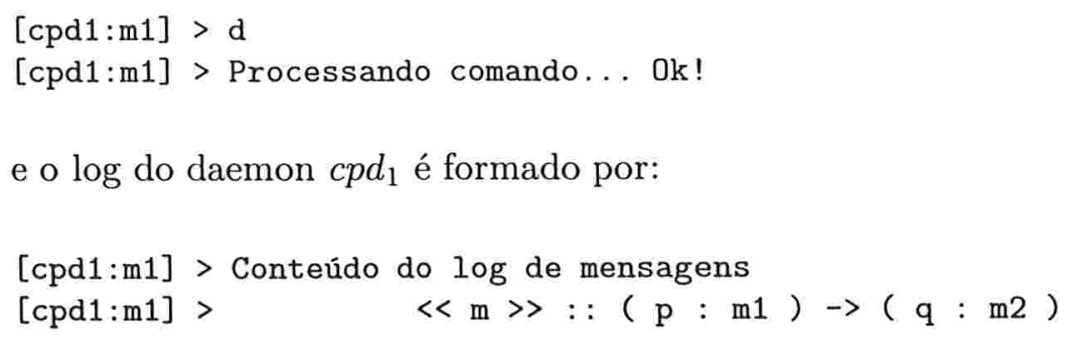

No restante do texto simplificaremos a exibição dos comandos do gerenciador para diminuir o conteúdo de informações pertinentes a cada seção. Por exemplo, apresentaremos os comandos no formato:

$\mathrm{p}$ q $\mathrm{m} 2$

ao invés de um nível maior de detalhes obtido por

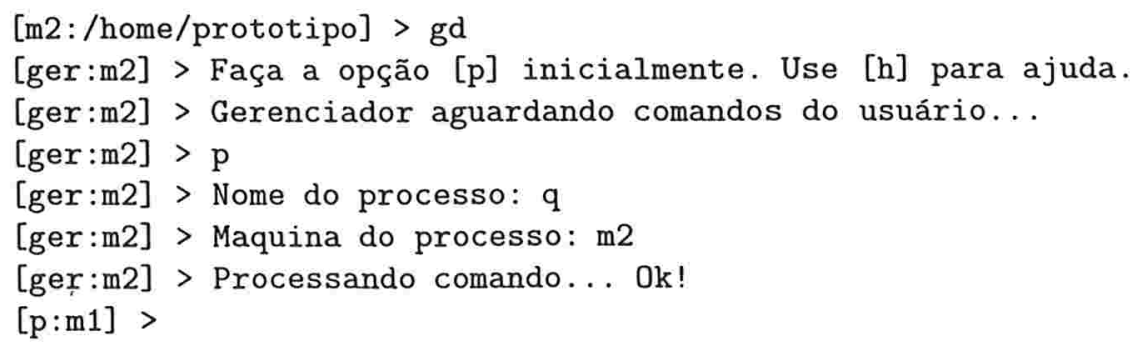

Observe que os dois tipos de apresentação possuem o mesmo significado: conectar o gerenciador ao processo $\left(\mathrm{q}: m_{2}\right)$. Finalmente, para conectar o processo remetente $\left(\mathrm{p}: m_{1}\right)$ ao processo $\left(\mathrm{q}: m_{2}\right)$ e enviar $m$, usamos, nesta nova representação, o seguinte conjunto de comandos:

c $\mathrm{p} \mathrm{m} 1 \mathrm{q} \mathrm{m} 2$

$\mathrm{s} \mathrm{m}$ 


\subsection{Informações e estruturas de dados}

Nesta seção descrevemos as informações e estruturas de dados empregadas em cada componente para dar uma idéia da instrumentação do protótipo.

\subsubsection{Supervisor do sistema}

O supervisor possui duas listas ligadas: a primeira armazena informações sobre os processos de aplicação registrados e a segunda mantém as principais características dos daemons cadastrados. Vejamos, agora, em mais detalhes, a estrutura de dados representante da primeira lista.

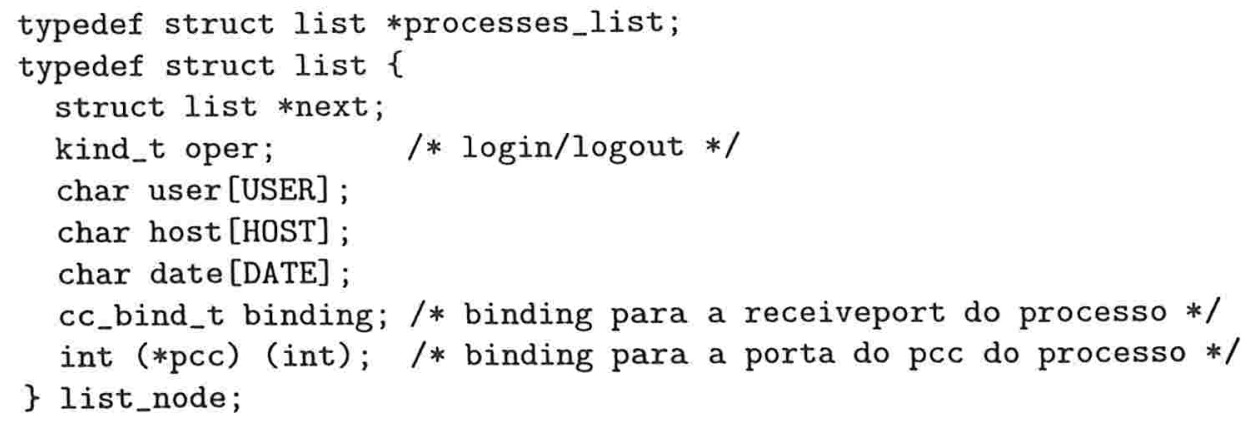

Os campos user, host e date são utilizados para identificar o processo de aplicação e a hora em que o registro foi realizado, e o campo oper pode conter os valores login ou logout, indicando se o processo iniciou ou finalizou a participação no protocolo de rastreamento de mensagens. Os dois bindings são relativos a receiveport do processo e a porta de recepção do ack:rsn, conforme requisição do protocolo de comunicação confiável, descrito na seção 3.2.2.

A generalização do protótipo, no que diz respeito ao número de portas definidas em cada processo, é feita expandindo-se a estrutura acima para aceitar várias portas de comunicação de diversos tipos, ao invés de possuir apenas uma porta do tipo de dados string representado por cc_bind_t.

A lista que armazena informações sobre os daemons cadastrados tem uma estrutura bastante semelhante:

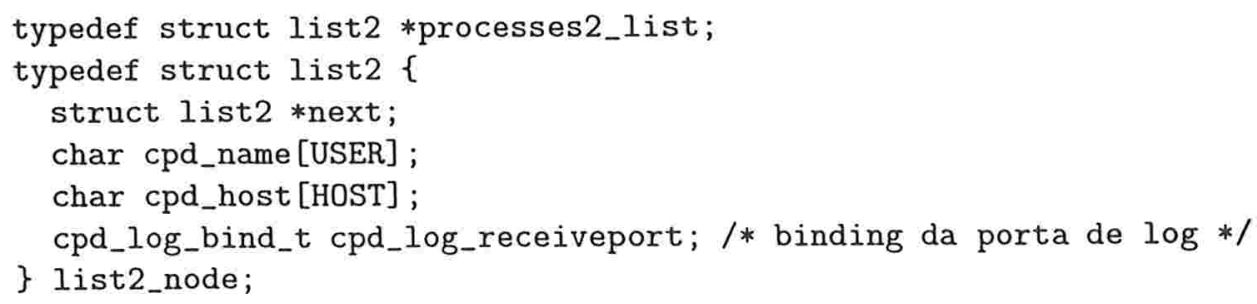

Os campos cpd_name e cpd_host identificam o daemon perante os mecanismos de checkpoin- 
ting, e cpd_log_receiveport é o binding para a porta de log.

\subsubsection{Checkpoint daemons}

Os checkpoint daemons definem a seguinte estrutura de dados, representante do log de mensagens.

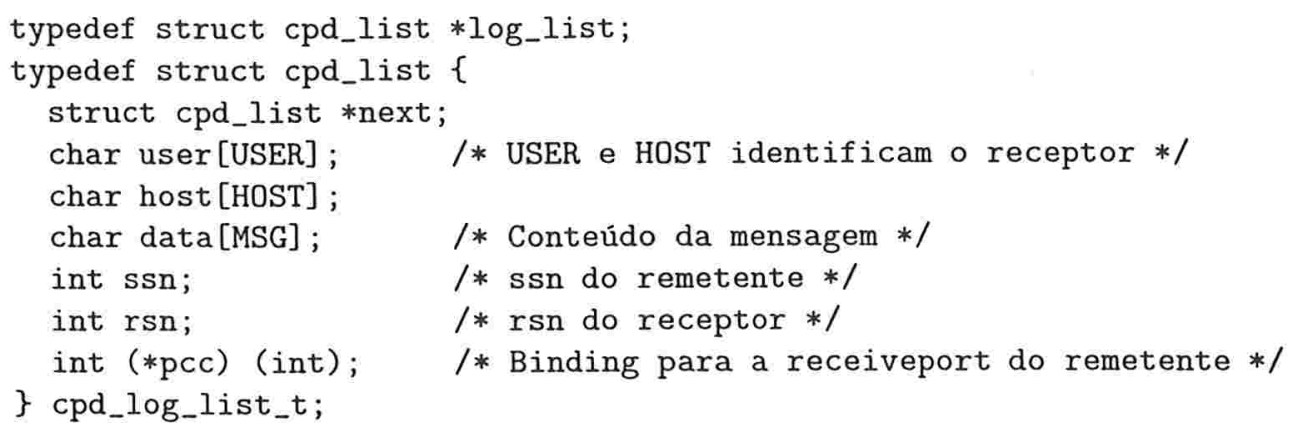

O nome do processo receptor e a máquina em que ele executa são armazenados em user e host, respectivamente. Isto equivale ao valor rec definido no protocolo de rastreamento de mensagens. O conteúdo da mensagem é armazenado em data e os valores ssn e rsn relativos à cópia da mensagem recebida são armazenados nos respectivos campos.

Por último, mas não menos importante, temos o binding para a função pcc do processo remetente, que toma um inteiro como parâmetro e retorna um inteiro. Ela é utilizada pelo processo receptor para retornar ao remetente o valor $r s n$ atribuído a mensagem. Por exemplo, se $p$ é o processo remetente e $q$ ' a nova instância, quando o daemon sequenciador enviar a mensagem armazenada em seu log a $q^{\prime}$, o protocolo de comunicação confiável será completado entre $p$ e $q$ ', e não entre o daemon e a nova instância, de forma que é necessário armazenar o binding da porta $p c c$ do remetente nesta estrutura de dados.

\subsubsection{Processos de aplicação}

Os processos de aplicação definem apenas uma estrutura de dados, utilizada para gerenciar diversos envios de mensagens parcialmente armazenadas. Por exemplo, se um processo $p$ envia $n$ mensagens, ele armazena referências a elas nesta estrutura de dados e, à medida que os valores rsn relativos ao protocolo de comunicação confiável vão chegando, as cópias das mensagens (agora totalmente armazenadas) são enviadas ao daemon local.

Se observarmos com atenção, veremos que esta estrutura é idêntica à definida nos daemons do sistema, com exceção de que o último campo não está presente na primeira. Ele é necessário para que a mensagem parcialmente armazenada seja enviada novamente após o restabelecimento de estado de um processo faltoso. Por exemplo, suponhamos que das $n$ mensagens enviadas, $k$ tenham 


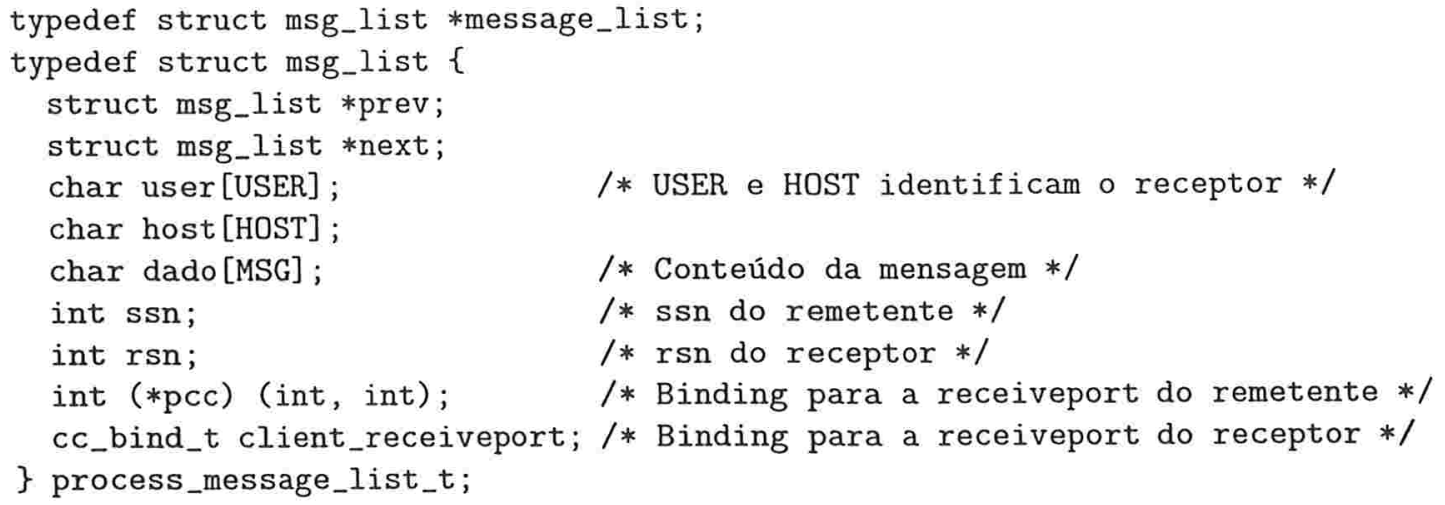

sido remetidas ao processo faltoso $q$. Após a nova instância $q$ ' restabelecer o estado, $p$ irá remeter $k$ mensagens a $q$ ', usando, para tanto, o binding atualizado contido em client receiveport.

\subsection{Possíveis extensões}

A seguir discutimos as simplificações e restrições do protótipo em relação ao serviço de checkpointing a ser implementado no Sampa, descrevendo possíveis extensões. É importante mencionar, mais uma fez, que estas poucas restrições não dizem respeito ao método de rastreamento de mensagens propriamente dito, mas a certos detalhes ligados à forma de funcionamento das outras componentes do sistema Sampa.

- De todas as extensões, acreditamos que as mais complexas sejam integrá-lo às demais componentes do Sampa e transcrever alguns trechos do código para sintaxe do ambiente DCE;

- Com relação a substituição de nosso supervisor pelo utilizado no Sampa, parece-nos que não haverá grandes problemas, pois toda a funcionalidade de nosso supervisor estará presente neste último;

- Outra extensão constitui em generalizar o número e tipo das portas de comunicação disponíveis em cada processo de aplicação. De uma forma geral, basta alterar a estrutura de dados definida no supervisor (veja seção 5.6.1) e as funções relacionadas para que esta extensão se concretize;

- Com relação ao conteúdo do estado relevante, temos certeza de que a generalização é trivial, pois basta ao programador definir todas as variáveis do código da aplicação que devem pertencer ao estado relevante. $\mathrm{O}$ pre-processador para a geração de procedimentos de leitura e escrita de valores de variáveis e estruturas de dados no padrão XDR está sendo desenvolvido em outro trabalho; 
- A adaptação do protótipo relativo aos passos utilizados para sincronizar as ações entre as componentes do sistema durante a execução da nova instância é bastante simples de ser implementado. Os timeouts relativos a transmissão de mensagens ao daemon sequenciador podem ser trivialmente substituídos por delimitadores (veja seção 5.3.3), e as comunicações entre a nova instância e os daemons após o consumo das mensagens totalmente armazenadas (veja passo 7 na seção 5.3.3) são facilmente adaptáveis às definições originais, já que as rotinas que efetuam tais comunicações já são utilizadas pelas componentes do sistema. 


\section{Capítulo 6}

\section{Exemplos de utilização do protótipo}

A seguir apresentamos três exemplos de execução do protótipo elucidando aspectos básicos e avançados do protocolo de rastreamento de mensagens implementado. Na verdade, o protótipo foi testado com um conjunto bastante grande de exemplos e padrões de comunicação do qual apresentamos apenas os casos mais significativos.

Em nossos exemplos nomeamos os processos de aplicação $c_{i}$, e usamos três máquinas em rede, denominadas catatau, mafalda e brucutu, cada uma delas executando o sistema operacional Unix (Sun OS 4.3.1) com o ambiente de interface gráfica XWindows.

Omitiremos detalhes sobre a instanciação das componentes e seremos breves também na explanação do significado e dos resultados da execução de cada comando do gerenciador, pois isto foi descrito em detalhes no capítulo anterior.

\subsection{Avaliando propriedades básicas}

Nosso primeiro teste mostra que o protótipo tem as propriedades básicas do método de rastreamento de mensagens e restabelece corretamente o estado da nova instância de um processo faltoso. Os aspectos avaliados são:

1. Contadores de mensagens enviadas (ssn) e recebidas (rsn) utilizados pelo método de rastreamento de mensagens e representantes do estado relevante funcionam corretamente durante o restabelecimento de estado;

2. A correta construção dos logs de mensagens nos daemons do sistema;

3. Habilidade dos processos de aplicação em detectar falha;

4. Simulação de falha em um processo;

5. Leitura do estado relevante relativo ao último checkpointing; 
6. Mecanismo de retransmissão de mensagens ao daemon sequenciador e consumo das mensagens retransmitidas pelo mesmo à nova instância foi implementado conforme estabelecido nos passos gerais da seção 5.3.3;

7. A rejeição de mensagens enviadas em duplicidade pela nova instância durante o restabelecimento de estado;

8. Reconstrução do estado local (representado pelas variáveis ssn e rsn);

9. Correta continuidade da execução do sistema após o restabelecimento de estado para a versão determinística do protótipo.

A configuração inicial do sistema é ilustrada pela figura 6.1, consistindo de um supervisor instanciado na máquina catatau, um checkpoint daemon em cada máquina e três processos: $c_{1}$ executando na máquina catatau, $c_{2}$ na mafalda e $c_{3}$ na brucutu. O gerenciador é instanciado na máquina brucutu. Em nossa figura excluímos a representação do supervisor e do gerenciador por serem de pouca relevância para a compreensão do exemplo.

Os números entre parêntesis indicam os valores dos contadores locais ssn e rsn (nesta ordem) relativos a mensagem enviada. Estes valores serão utilizados para demonstrar a correta construção do estado local da nova instância.

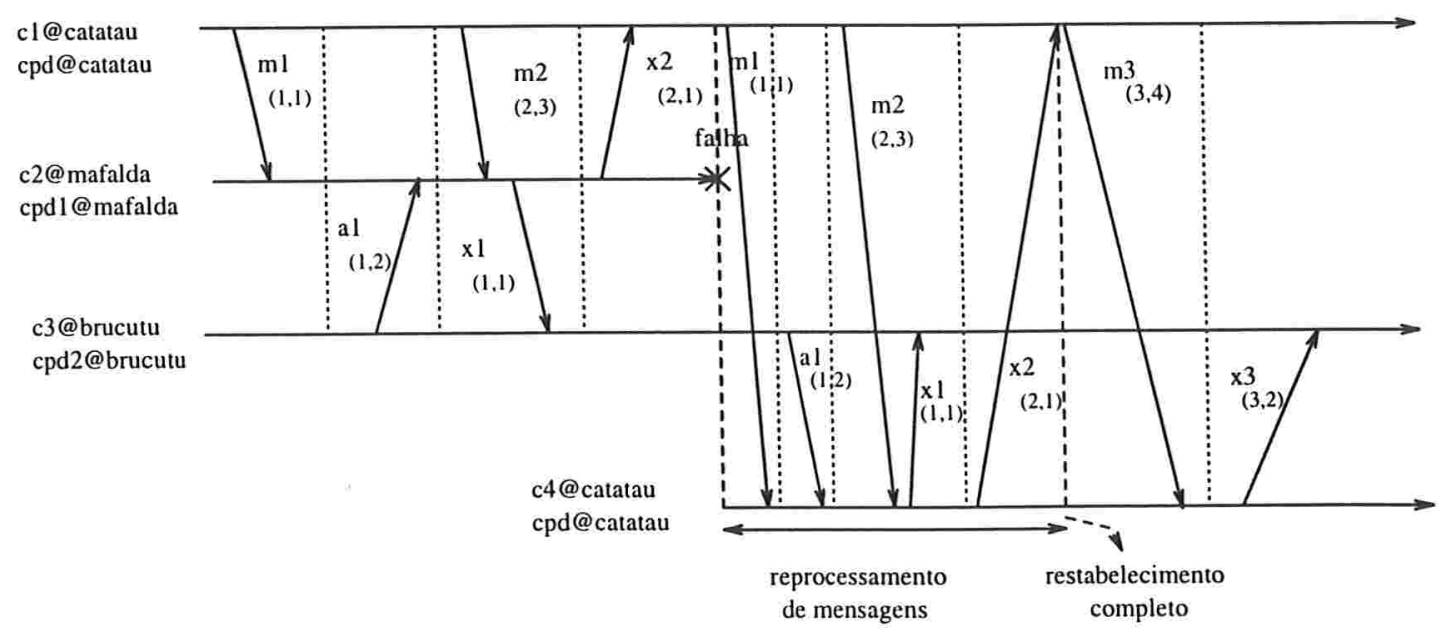

Figura 6.1: Diagrama de eventos

A nova instância ( $c_{4}$ : catatau ) iniciará a execução após a morte do processo ( $c_{2}:$ mafalda $)$. Em seguida, haverá uma etapa inicial de reprocessamento de mensagens envolvendo os daemons do sistema, que reconstruirá o estado local da nova instância. Finalmente, a execução do sistema continua com o envio das mensagens $m_{3}$ e $x_{3}$, ilustrando que a nova instância tem condições de interagir com ambiente de execução de processos. 


\subsubsection{Processamento normal do sistema}

Após instanciar as componentes do sistema, o usuário pode solicitar comandos ao gerenciador para construir a configuração do sistema desejada. Ilustraremos detalhadamente como produzir o conjunto de eventos ilustrados na figura 6.1 até o momento da falha.

Cada traço vertical pontilhado corresponde a um conjunto de eventos executados no sistema. Por exemplo, o primeiro traço indica a ocorrência do evento de envio da mensagem $m_{1}$ no processo ( $c_{1}$ : catatau ) e o correspondente recebimento em ( $c_{2}$ : mafalda ).

A seguir detalhamos alguns eventos para verificar as características do protótipo especificadas no início desta seção. Iniciamos pela primeira e segunda características que mostram a correta funcionalidade dos contadores de mensagens e a construção dos logs de mensagens nos daemons, usando, para tanto, o evento de envio da mensagem $m_{1}$ como exemplo.

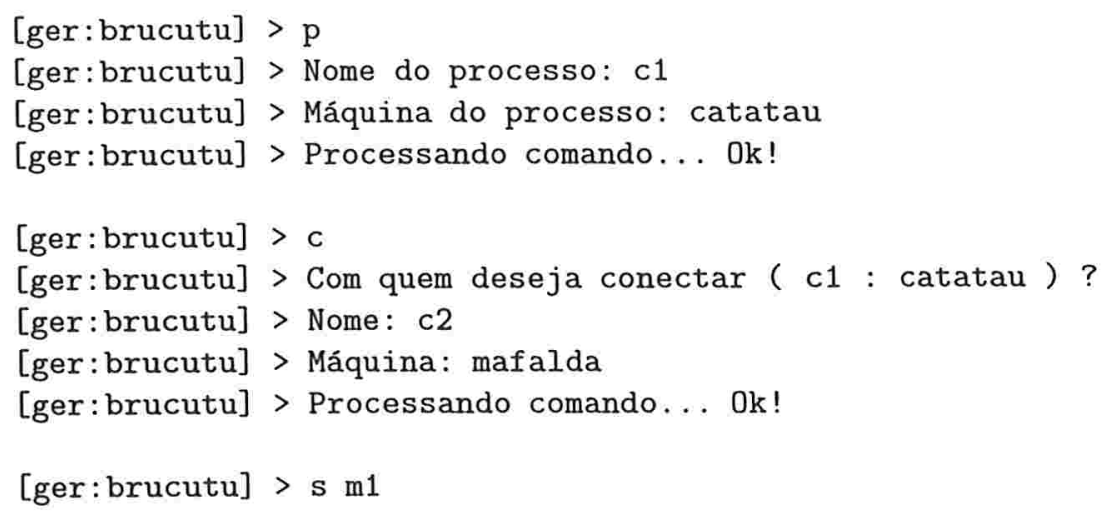

O resultado da conexão entre os processos e do envio da mensagem $m_{1}$ é exibido no xtem do remetente $\left(c_{1}:\right.$ catatau $)$ desta forma:

[c1: catatau] > Conectando processo ( c2 : mafalda )...0k, conectado.

[c1: catatau] $>+++$ enviado $\ll m 1 \gg$ a ( $c 2$ : mafalda ) sob $s s n=1$

[c1: catatau] $>+++$ enviado copia de $\ll m 1 \gg$ a ( cpd : catatau ) sob (ssn=1, rsn=1)

No xterm do destinatário ( $c_{2}:$ mafalda ), é exibida a notificação:

$[\mathrm{c} 2$ :mafalda $]>--$ Chegou $\ll \mathrm{m} 1 \gg$ de $(\mathrm{c} 1$ : catatau $), \mathrm{ssn}=1$, retornando $\mathrm{rsn}=1$

Para finalizar, o daemon local à máquina catatau exibe uma informação relatando o recebimento da cópia de $m_{1}$ :

[cpd:catatau] $>\mathrm{msg} \ll \mathrm{m} 1 \gg$ destinada a ( $\mathrm{c} 2$ : mafalda ) incluída no $\log (\mathrm{ssn}=1, \mathrm{rsn}=1)$

O processo ( $c_{1}$ : catatau ) informa ao usuário que $m_{1}$ foi enviada ao processo ( $c_{2}:$ mafalda ) com sucesso, e que uma cópia da mesma foi remetida ao daemon local. Adicionalmente, podemos notar os valores atribuídos aos contadores $s s n$ e $r s n$ : o contador $s s n$ vale 1 , dado que $m_{1}$ foi a 
primeira mensagem enviada pelo remetente ( $c_{1}$ : catatau ); o valor do contador rsn é também 1 , pois $m_{1}$ representa a primeira mensagem recebida por ( $c_{2}:$ mafalda $)$.

A seguir exibimos mais um envio de mensagem para destacar a terceira característica do protótipo: a deteç̧ão de falhas. Neste exemplo, o processo ( $c_{3}:$ brucutu ) envia a mensagem $a_{1}$ a ( $c_{2}$ : mafalda ) e a demora na recepção do valor $r s n$ o faz suspeitar da morte em $c_{2}$. Isto evidencia que se o protocolo de comunicação confiável demorar mais do que o tempo estimado para ser completado, o remetente tem condições de detectar esta demora e suspeitar da falha no receptor, aguardando, em seguida, uma notificação do gerenciador confirmando o fato.

Neste exemplo, o valor rsn chega antes da expiração tempo limite (estimado em 3 segundos), de forma que o protocolo de comunicação confiável foi completado e tudo se passou como se a suspeita de falha não houvesse ocorrido. Na próxima seção estudaremos um caso em que a suspeita se concretiza.

$\mathrm{Na}$ ilustração deste evento de envio de mensagens e em todos os seguintes usaremos a forma simplificada para exibir os comandos do gerenciador, conforme discutido na seção 5.5. A situação acima descrita é feita pelo seguinte conjunto de comandos:

p c3 brucutu

c c2 mafalda

s a1

O resultado da solicitação de conexão e envio da mensagem são exibidos no xterm do remetente $\left(c_{3}\right.$ : brucutu ) desta forma:

[c3:brucutu] > Conectando processo ( c2 : mafalda )...0k, conectado.

[c3:brucutu] $>+++$ enviado $\ll$ a1 $\gg$ a ( c2 : mafalda ) sob ssn=1

[c3:brucutu] $>$ morte em ( c2 : mafalda )... 1 em 3

[c3:brucutu] > +++ enviado copia de $<$ a1 $\gg$ a ( cpd2 : brucutu ) sob (ssn=1, rsn=2)

A penúltima linha da notificação informa ao usuário que passou 1 segundo (em um máximo de 3) e o valor $r s n$ ainda não foi retornado pelo receptor ( $c_{2}:$ mafalda ). A próxima notificação informa que uma cópia da mensagem foi remetida ao daemon local, indicando que o protocolo de comunicação foi completado antes da expiração do tempo limite. Situações como esta de suspeita parcial de falha podem ser evidenciadas quando o tráfego de mensagens na rede é alto. As notificações sobre o recebimento da mensagem $a_{1}$ pelo receptor $\left(c_{2}:\right.$ mafalda $)$ e o correspondente armazenamento da cópia pelo daemon local não são exibidas por serem semelhantes às descrições anteriores.

Os comandos que levam o sistema ao estado imediatamente anterior a simulação de falha no processo ( $c_{2}$ : mafalda ) são exibidos abaixo, mas não entraremos em detalhes sobre os resultados de sua execução devido a grande similaridade com os dois eventos ilustrados acima. No entanto, gostaríamos de destacar a correta atribuição de valores aos contadores de mensagens ssn e rsn por parte dos processos envolvidos no protocolo de comunicação confiável bem como o correto armazenamento das cópias das mensagens no log dos daemons locais.

p c1 catatau 


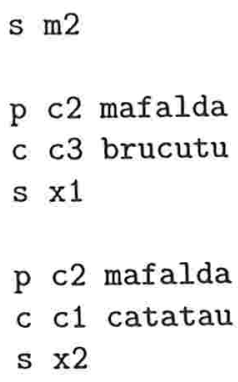

Agora, detalhamos as fases envolvidas na simulação de falha no processo ( $c_{2}:$ mafalda ), ilustrando, portanto, a quarta característica. Antes de prosseguir, exibiremos o conteúdo do log de mensagens de cada daemon para ilustrar a correta atribuição de valores aos contadores de mensagens. Isto pode ser feito através dos seguintes comandos:

n cpd catatau d

n cpd1 mafalda d

n cpd2 brucutu d

e o resultado de sua execução é:

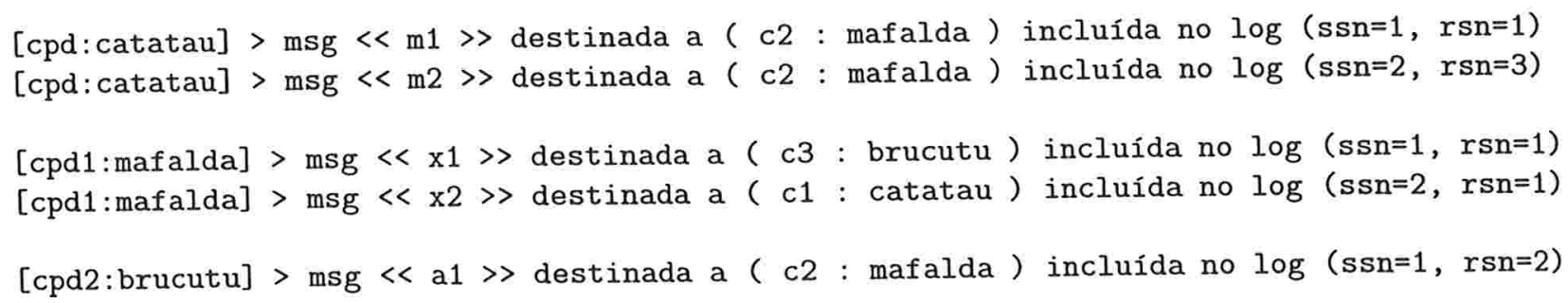

Portanto, as mensagens trocadas pelas componentes através dos comandos exibidos acima realmente constróem a configuração de mensagens ilustrada na figura 6.1. Convém observar que se estivéssemos utilizando a versão indeterminística, obteríamos, com grande probabilidade, valores diferentes nas variáveis ssn e rsn representantes do estado relevante, já que cada envio seria precedido de um delay, simulando um processamento interno em cada processo. Como observaremos em seguida, o restabelecimento de estado da nova instância será completado com sucesso independente dos valores atribuídos aos contadores em questão, evidenciando que a versão utilizada não influencia nos resultados.

\subsubsection{Simulando falha em um processo de aplicação}

Para simular a falha, o usuário deve interagir com o gerenciador desta forma:

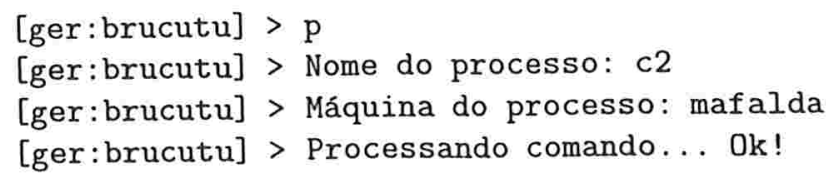


[ger:brucutu] $>\mathrm{m}$

$[p: m 1]>$ Processo a ser morto: ( c2 : mafalda)

$[\mathrm{p}: \mathrm{m} 1]>$ Nome da nova instância: $c 4$

$[\mathrm{p}: \mathrm{m} 1]>$ Em que máquina: catatau

[p:m1] > Requisitando finalização no protótipo a ( c2 : mafalda )

$[\mathrm{p}: \mathrm{m} 1]>$ Processando comando... Ok!

O primeiro comando conecta o gerenciador ao processo $\left(c_{2}:\right.$ mafalda $)$. O segundo simula a falha na componente conectada, informando ao gerenciador o nome e máquina da instância substitutiva. O resultado da simulação de falha é assim exibida no xterm do processo $c_{2}$ :

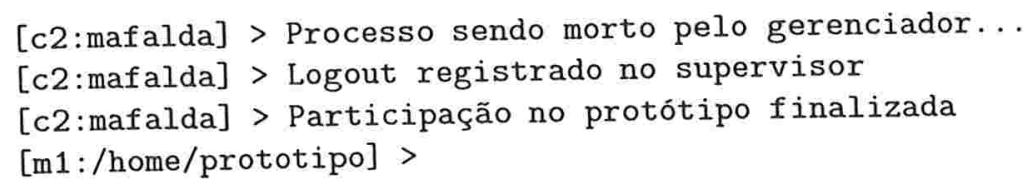

Com isto, finalizamos a execução por vias normais, ou seja, é registrado um logout no supervisor seguido de um abandona, retornando, em seguida, à linha de comando do Unix. Como já mencionamos anteriormente, o Sampa fornecerá mecanismos para monitoramento e detecção de falha em processos, mas tais facilidades não se encontravam disponíveis no momento em que nosso protótipo estava sendo desenvolvido. Por isso, não é permito simular falhas usando, por exemplo, o kill -9 , visto que isto não notificaria o gerenciador. Em outras palavras, nosso protótipo assume a existência de um mecanismo de detecção de falhas.

\subsubsection{Restabelecendo o estado da nova instância}

Durante o restabelecimento de estado, o gerenciador comanda e sincroniza a execução das componentes, conforme descrito na seção 5.3.3. Gostaríamos de salientar que no Sampa estas tarefas serão executadas pelo supervisor do sistema e pelo agente local à máquina em que a instância faltosa executava.

Inicialmente, o gerenciador notifica o supervisor para manter uma referência sobre a substituição dos processos, conforme descrito na primeira notificação exibida abaixo.

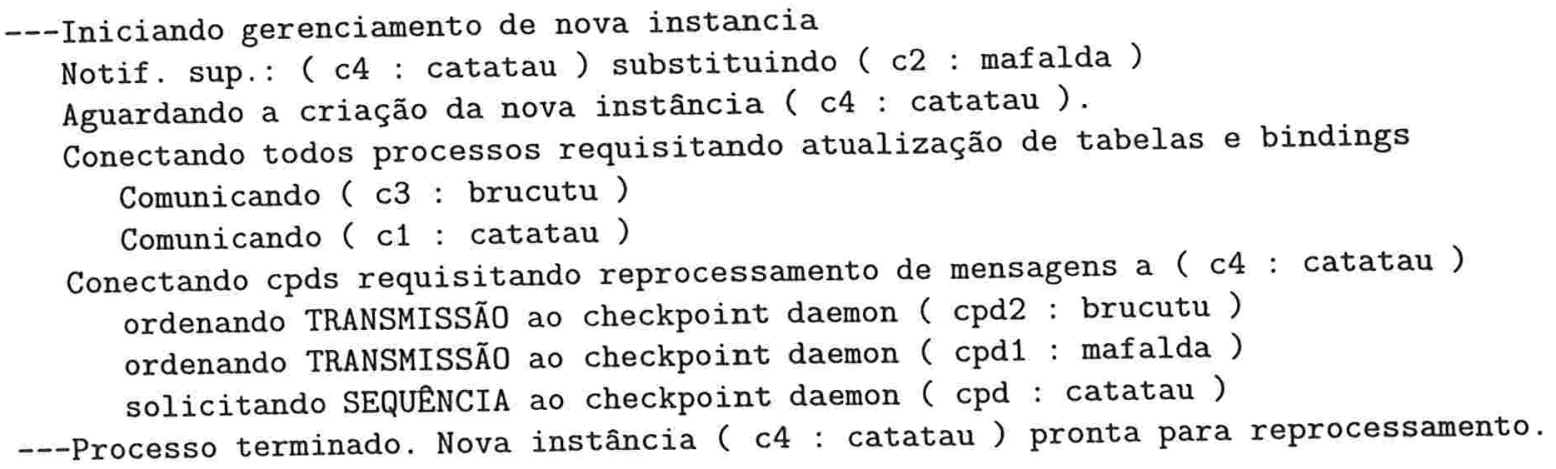


Após a criação da nova instância pelo usuário, o gerenciador comunica todos os processos de aplicação do sistema para atualizarem a identidade da instância substituta nas tabelas requeridas pelo método de rastreamento de mensagens e para obterem junto ao supervisor o binding da receiveport da nova instância.

Em seguida, o gerenciador envia comandos aos daemons informando-os sobre quais tarefas deverão realizar. É neste instante que é definido quem será o daemon sequenciador e quais serão os transmissores. A regra que os define é a seguinte: o sequenciador é o daemon local à máquina em que a nova instância executa; os demais serão os daemons transmissores.

Isto finaliza a participação do gerenciador no restabelecimento de estado e o restante da operação envolve os daemons, o supervisor e os processos de aplicação. Antes de prosseguir, no entanto, é importante observar duas consequências do conjunto de ações acima. Uma delas diz respeito à nova instância, e a outra é relativa aos demais processos de aplicação do sistema.

Após ser criada, a nova instância realiza todas as tarefas usuais (registrar login e se conectar ao daemon local), lê o estado relevante do disco e entra em estado de reprocessamento de mensagens. Neste exemplo, o estado relevante é formado por ssn e $r s n$ nulos, pois a instância faltosa efetuou um checkpointing imediatamente após iniciar a execução. Na próxima seção ilustraremos uma situação em que o processo efetua um checkpointing adicional antes de sofrer a falha.

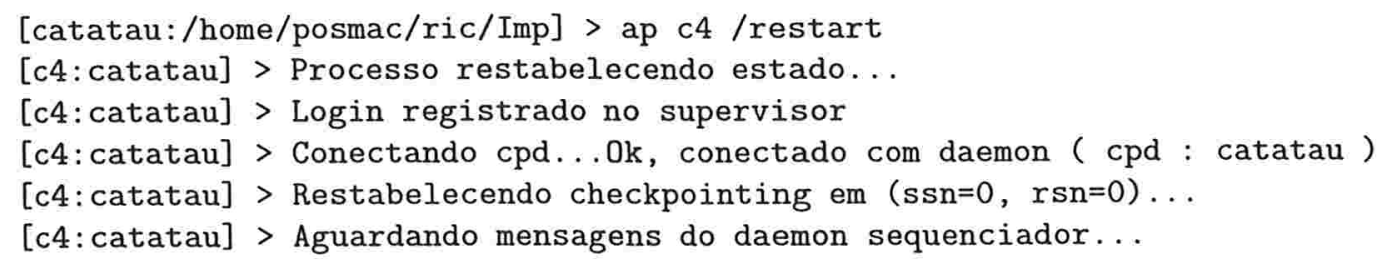

No conjunto de notificações exibidas abaixo, o processo ( $c_{1}:$ catatau ) informa ao usuário o resultado da solicitação de atualização de tabelas e bindings. Adicionalmente, $c_{1}$ aguarda o reprocessamento das mensagens totalmente armazenadas pela nova instância, isto é, ele não enviará nenhuma mensagem parcialmente armazenada à nova instância até que o reprocessamento das mensagens enviadas pelo daemon sequenciador seja concluído. Isto não significa, no entanto, que $c_{1}$ está momentaneamente indisponível, pois é permitido a ele se comunicar com qualquer outro processo do sistema, inclusive receber mensagens e completar o protocolo de comunicação com a nova instância quando for necessário.

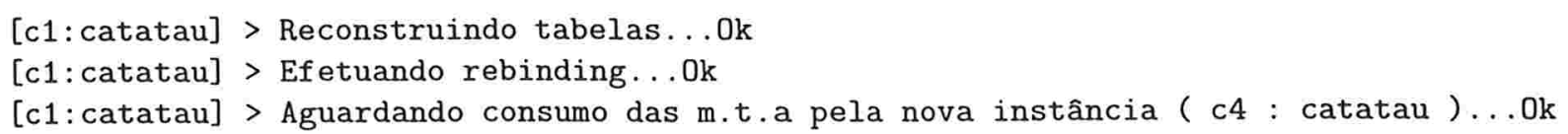

A seguir descrevemos a interação entre os daemons no restabelecimento de estado. Inicialmente, o daemon ( $c p d_{1}$ : mafalda ) remove de seu log qualquer mensagem enviada pelo remetente faltoso. Isto é necessário porque a nova instância as enviará novamente durante o restabelecimento de estado, e o daemon local à máquina em que ela executa - ( cpd : catatau ) neste exemplo - será o responsável por armazená-las, evitando, portanto, duplicidade de mensagens nos logs.

Em seguida, o daemon atualiza referências relativas à instância morta em seu log, e inicia a transmissão de mensagens ao daemon sequenciador. É importante observar que é suficiente 
transmitir as mensagens recebidas pela instância faltosa após o último checkpointing efetuado, representado pela restrição $r s n>0$ (veja mais detalhes sobre isto na seção 5.3.3).

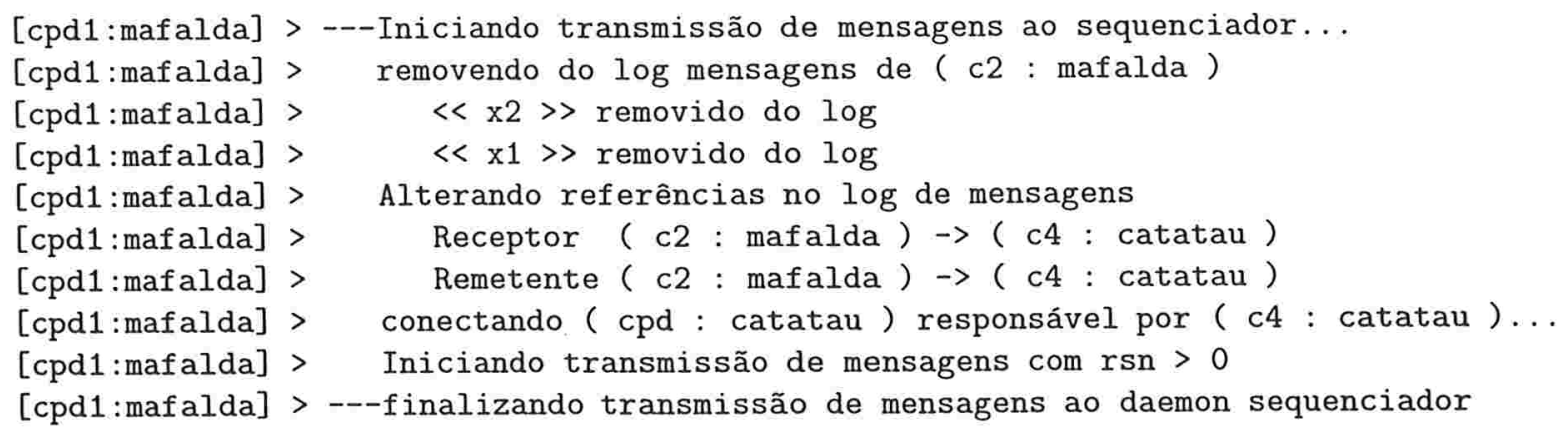

Observe que o daemon ( $c p d_{1}:$ mafalda ) não transmitiu mensagens ao daemon sequenciador, pois a instância faltosa não recebeu nenhuma mensagem de processos que executam na máquina mafalda. No entanto, o daemon ( $c p d_{2}$ : brucutu ) envia ao sequenciador a mensagem $a_{1}$, conforme representado abaixo.

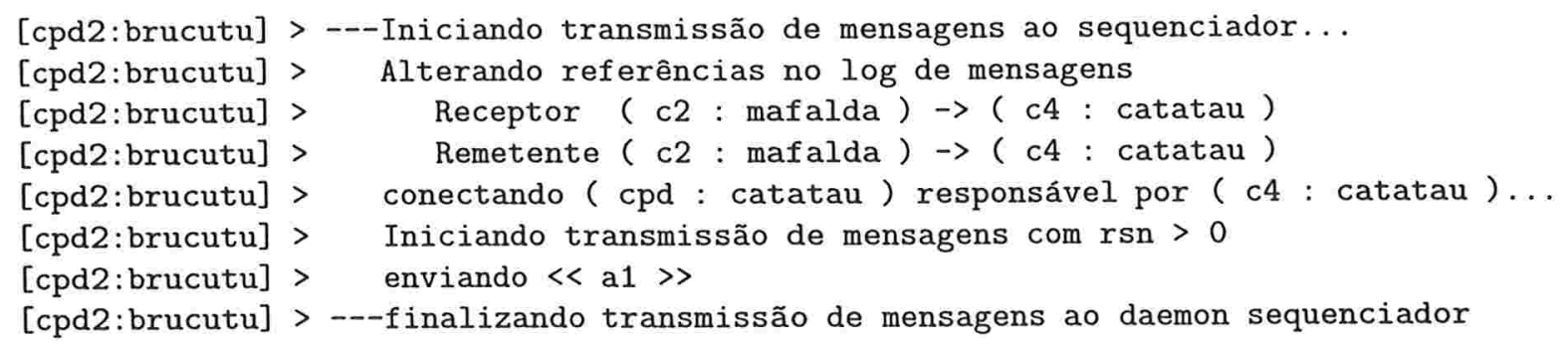

O daemon sequenciador realiza a mesma tarefa de atualização de bindings no log de mensagens e, em seguida, constrói a bag (veja seção 5.3.3 para mais detalhes sobre o significado e sua estrutura de dados) a partir do log de mensagens local, donde verificamos que as mensagens $m_{1}$ e $m_{2}$ serão retransmitidas à nova instância. Finalmente, o daemon inclui na bag as mensagens enviadas pelos daemons transmissores, e inicia a retransmissão de mensagens à nova instância, em ordem crescente de valores $r s n$. Isto finaliza a participação dos daemons no restabelecimento de estado.

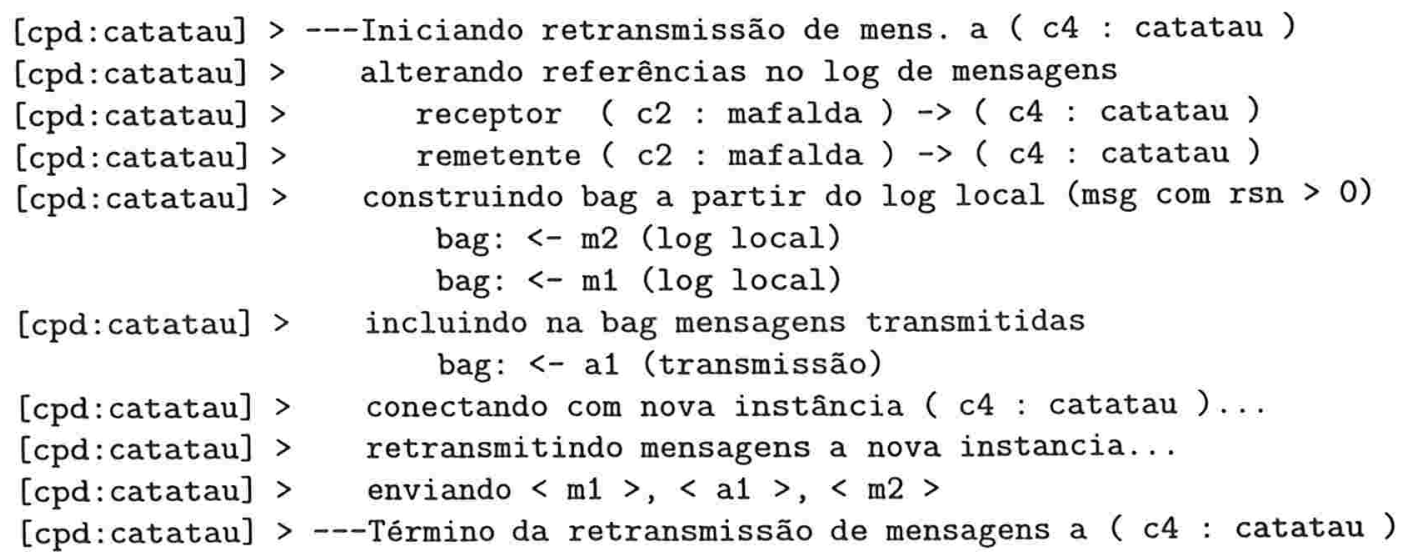


É importante observar que apenas as mensagens totalmente armazenadas realmente necessárias para reconstruir o estado local da nova instância são armazenadas na bag. Isto pode ser verificado pelo fato de que todos os daemons selecionam apenas as mensagens cujo valor $r s n$ é maior que o valor $r s n$ relativo ao último checkpoint local efetuado pela instância faltosa.

A seguir estudamos os passos envolvendo os processos de aplicação durante o reprocessamento das mensagens totalmente armazenadas. A medida que a nova instância recebe as mensagens do daemon sequenciador, ela entra em contato com os respectivos processos remetentes para enviar o valor $r s n$ relativo ao protocolo de comunicação confiável, como podemos ver no seguinte evento de recepção de $m_{1}$.

[c4:catatau] > --- Chegou $\ll m 1 ~ \gg$ de ( $c 1$ : catatau ), ssn=1, retornando rsn=1

Ao receber a mensagem, o remetente ( $c_{1}$ : catatau $)$ e a nova instância seguem o protocolo de comunicação confiável, fazendo o receptor $c_{4}$ retornar o mesmo valor $r s n$ atribuído a $m_{1}$ originalmente. Isto pode ser verificado se compararmos o conteúdo dos xterms da nova instância e da instância morta em relação ao evento de recebimento desta mensagem. Note que o remetente pode ignorar o valor rsn recebido, pois ele já o possui armazenado em sua tabela de valores rsn, quando $m_{1}$ foi enviada originalmente pela instância faltosa.

Da mesma forma, o evento de recebimento de $a_{1}$ causará a execução do protocolo de comunicação entre o remetente $\left(c_{3}\right.$ : brucutu ) e a nova instância, retornando o valor de $r s n$ esperado.

[c4:catatau] > -- Chegou $\ll$ a1 $\gg$ de ( c3: brucutu ), ssn=1, retornando rsn=2

Vejamos, agora, as etapas envolvidas no envio da mensagem $x_{1}$ pela nova instância. Ao enviála, o receptor $c_{3}$ retornará o valor $r s n$ atribuído originalmente a $x_{1}$, e adicionalmente informará ao usuário a rejeição da mesma, visto que ela foi enviada em duplicidade. Isto pode ser verificado através das seguintes notificações:

[c4: catatau] > Conectando processo ( c3 : brucutu )...0k, conectado.

[c4: catatau] $>+++$ enviado $<<1>$ a ( c3: brucutu) sob (ssn=1)

[c4: catatau] $>+++$ enviado copia de $\ll x 1 \gg$ a ( cpd : catatau ) sob (ssn=1, rsn=1)

[c3:brucutu] > Mensagem $x 1$ rejeitada como duplicada (retornando $r s n=1$ ).

Para finalizar, é interessante destacar que o envio da mensagem $x_{1}$ causa o envio de uma cópia ao daemon local, como foi feito na fase de processamento normal do sistema. Como $x_{1}$ foi removida do $\log$ de mensagens do daemon ( $c p d_{1}$ : mafalda ), não existe mensagens duplicadas no $\log$ dos daemons do sistema.

[cpd:catatau] $>\operatorname{msg} \ll x 1 \gg$ destinada a ( c3: brucutu ) incluída no $\log (\mathrm{ssn}=1, \mathrm{rsn}=1)$

Ao finalizar o processamento das mensagens totalmente armazenadas, o checkpoint daemon ( cpd : catatau ) terá em seu log as mensagens iniciais adicionadas das mensagens $x_{1}$ e $x_{2}$ enviadas pela nova instância durante o restabelecimento de estado, conforme podemos observar a seguir: 
[cpd:catatau] $>$ msg $\ll x 1 ~ \gg$ destinada a ( c3 : brucutu) incluída no log (ssn=1, rsn=1)

[cpd: catatau] $>\operatorname{msg} \ll x 2 \gg$ destinada a ( $c 1$ : catatau) incluida no log (ssn=2, rsn=1)

Neste momento a nova instância restabeleceu completamente seu estado local.

\subsubsection{Continuidade do sistema após o restabelecimento}

A seguir processamos alguns eventos para mostrar que a nova instância está apta a interagir com o ambiente de execução de processos.

O envio da mensagem $m_{3}$ por ( $c_{1}$ : catatau ) causa as seguintes interações:

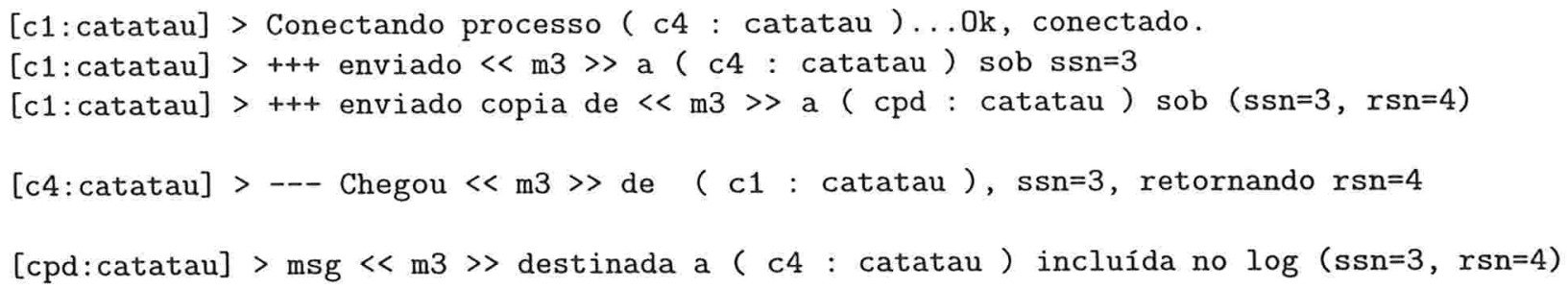

Portanto, a nova instância é capaz de receber mensagens e completar o protocolo de comunicação confiável. Vejamos, agora, a interação da nova instância com ( $c_{3}$ : brucutu ) em relação ao evento de envio da mensagem $x_{3}$.

[c4: catatau] > Conectando processo ( c3 : brucutu )...0k, conectado.

[c4: catatau] $>+++$ enviado $<$ x3 $\gg$ a ( c3 : brucutu ) sob ssn=3

[c4:catatau] $>+++$ enviado copia de $<$ x3 $\gg$ a ( cpd : catatau ) sob (ssn=3, rsn=2)

[c3:brucutu] $>---$ Chegou $\ll \times 3>$ de $(\mathrm{c} 4$ : catatau ), ssn=3, retornando rsn=2

[cpd:catatau] $>\operatorname{msg} \ll x 3 \gg$ destinada a ( c3 : brucutu ) incluída no log (ssn=3, rsn=2)

Como podemos verificar, a nova instância interage com o ambiente da forma esperada e os valores dos contadores $s s n$ e $r s n$ continuam a ser manipulados corretamente.

\subsubsection{Gráfico comparativo de tempos}

A seguir exibimos o gráfico de tempos 6.2 contendo os principais passos envolvidos desde a simulação de falha no processo ( $c_{2}$ : mafalda ) até o completo restabelecimento de estado da nova instância ( $c_{4}$ : catatau ).

Este gráfico apresenta o tempo consumido em cada etapa e o tempo acumulado para o caso particular desta configuração de processos estudada. O eixo horizontal representa a ação tomada pela componente do sistema (leia descrição detalhada abaixo) e o eixo vertical indica o tempo gasto em cada etapa e tempo total acumulado desde o início do restabelecimento de estado. 


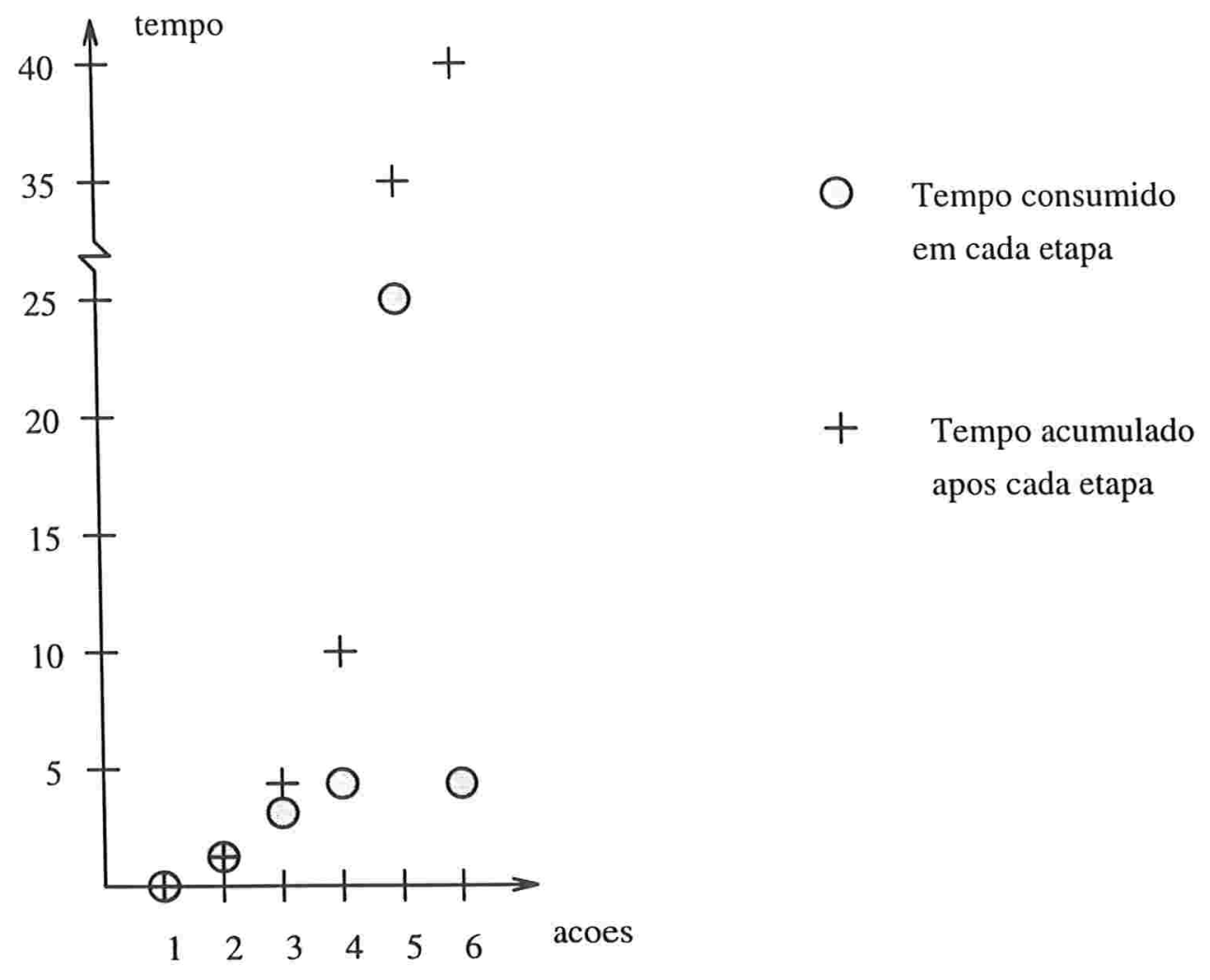

Figura 6.2: Gráfico comparativo de tempo

1. A primeira ação corresponde à morte do processo ( $c_{2}:$ mafalda $)$ pelo usuário.

2. Neste segundo passo, o usuário cria a nova instância e o gerenciador comunica o supervisor sobre a substituição dos processos. Esta etapa é estimada em 1 segundo.

3. A terceira tarefa consiste em contatar cada processo de aplicação para solicitar a atualização de tabelas e bindings. Isto leva aproximadamente 4 segundos.

4. A seguir o gerenciador se comunica com os daemons definindo quem será o sequenciador e quais daemons serão os transmissores. Esta etapa foi estimada em 5 segundos.

5. O quinto passo é o mais complexo de todos. Os daemons transmissores enviam as mensagens ao daemon sequenciador, que as remete à nova instância, em ordem crescente de valores $r s n$. De acordo com nossas medidas, esta fase foi estimada em torno de 25 segundos para o conjunto de daemons, processos e mensagens envolvidos. Convém lembrar que a maior parte deste tempo é relativa ao timeout descrito em detalhes na seção 5.3.3.

6. Nesta última fase, a nova instância processa as mensagens enviadas pelo daemon sequenciador e executa o protocolo de comunicação confiável com os demais processos de aplicação. O tempo estimado foi de 5 segundos para o conjunto de processos e mensagens em questão. 


\subsubsection{Consideração final}

Antes de exibirmos os próximos exemplos, gostaríamos de dizer que o estudo feito nesta seção utiliza praticamente toda a funcionalidade do protótipo, de forma que seremos bastante breves na exemplificação das interações entre as componentes nos próximos exemplos, procurando detalhar apenas as particularidades não ilustradas até agora.

Gostaríamos de destacar que utilizamos a versão determinística porque isto simplificou a explicação do exemplo em questão. A única diferença em relação a versão indeterminística é que os valores ssn e rsn representados em nossas figuras seriam diferentes, já que fatores relacionados ao tráfego de mensagens na rede e ao tempo de processamento dos eventos em cada processo os afetaria diretamente.

Para finalizar é importante observar que após o restabelecimento de estado, a nova instância ( $c_{4}$ : catatau ) e todos os processos de aplicação ficam a disposição do gerenciador para interpretação e execução de comandos solicitados pelo usuário. No terceiro exemplo estudaremos uma situação onde existam mensagens no canal de comunicação da instância faltosa, pois isto permitirá verificar que a nova instância tem condições de reprocessar inclusive estas mensagens, reforçando o fato de que todos os processos ficam completamente disponíveis ao usuário após o restabelecimento de estado.

\subsection{Processamento com checkpointing intermediário}

Neste segundo exemplo analisamos uma situação na qual o processo que apresenta a falha realiza um checkpointing adicional antes de finalizar a execução. A principal mudança ocorrida na interação entre as componentes do sistema é relativa às mensagens manipuladas pelos daemons, pois para o completo restabelecimento de estado, basta que a nova instância reprocesse as mensagens cujo valor rsn seja maior que o valor relativo ao último checkpointing efetuado pela instância faltosa.

Usaremos, basicamente, a mesma figura incluindo, apenas, o checkpointing intermediário efetuado pela instância ( $c_{2}$ : mafalda ), conforme ilustrado na figura 6.3.

Seremos bastante breves na exemplificação, devido a grande semelhança entre este exemplo e o anterior. Inicialmente, o usuário instancia cada componente do sistema e solicita ao gerenciador os comandos exibidos em detalhes na seção 6.1.1, adicionando o checkpointing intermediário exibido abaixo.

p c2 mafalda $k$

Ao solicitar o checkpoininting intermediário ao gerenciador, o processo ( $c_{2}$ : mafalda ) notifica o usuário desta forma:

[c2:mafalda] $>$ Efetuando checkpointing em ( $s s n=0: r s n=2) \ldots$ 


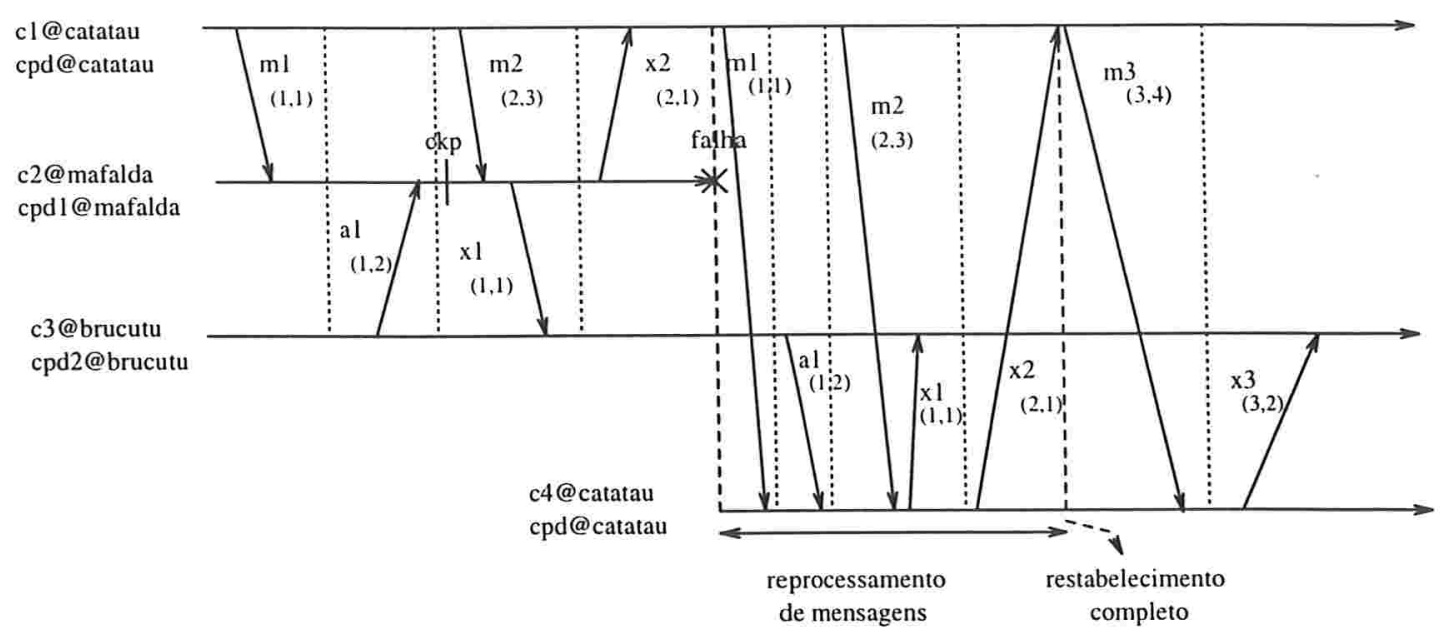

Figura 6.3: Diagrama de eventos com checkpointing intermediário

Como o checkpointing foi efetuado imediatamente após o recebimento da mensagem $a_{1}$, o valor do contador $r s n$ é exatamente 2 . O valor do contador ssn é zero porque o processo $c_{2}$ não enviou nenhuma mensagem até o momento em que gravou o estado relevante em disco.

\subsubsection{Restabelecendo o estado da nova instância}

Após simular a falha em ( $c_{2}:$ mafalda $)$ e criar a nova instancia $\left(c_{4}:\right.$ catatau $)$, o gerenciador contata todos os processos de aplicação e daemons do sistema, conforme estudado na seção anterior. As únicas modificações estão relacionadas à leitura do estado relevante pela nova instância e à seleção das mensagens pelos daemons do sistema. Vejamos isto em mais detalhes.

Ao iniciar a execução, a nova instância lê o estado relevante e detecta o checkpointing intermediário, conforme notificado abaixo.

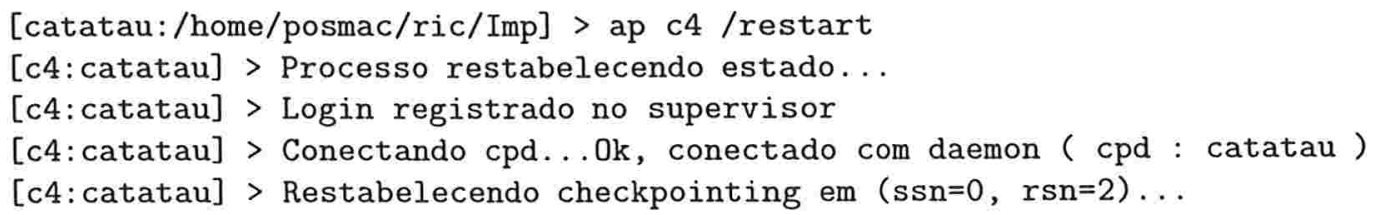

Durante a fase de transmissão de mensagens ao daemon sequenciador, os daemons transmissores notificam o usuário desta forma:

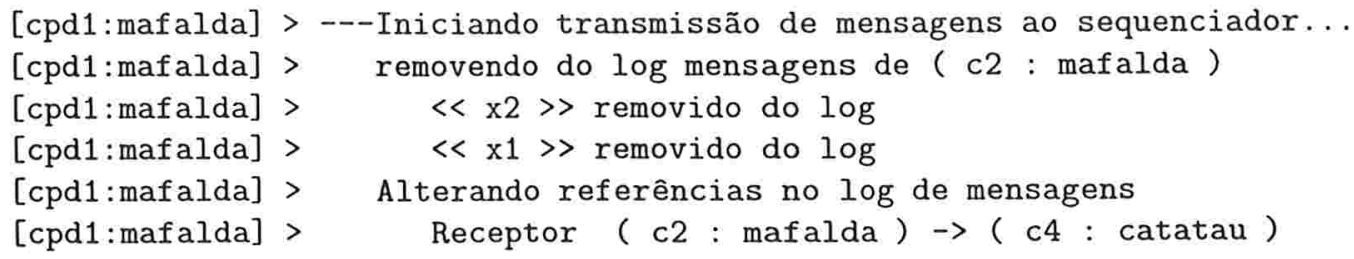




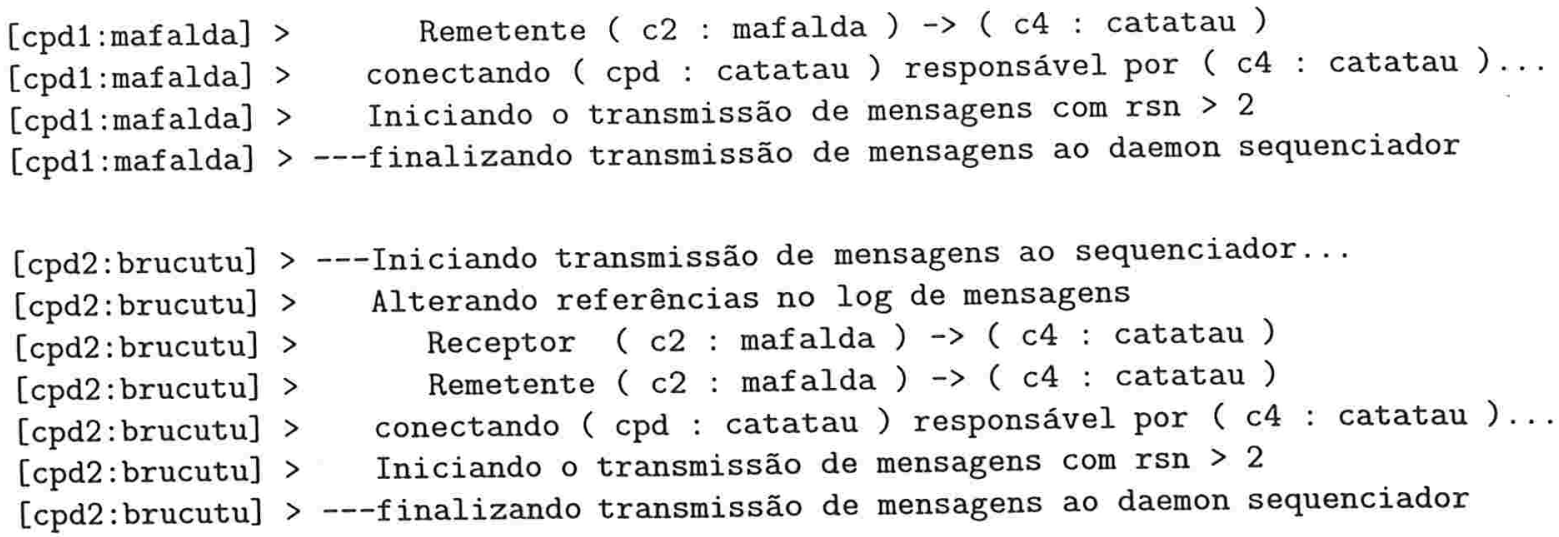

As informações acima permitem concluir que o daemon ( $c p d_{1}$ : mafalda ) não transmitiu mensagens ao daemon sequenciador, pois não há mensagens destinadas à instância morta em seu log local com valores rsn maiores que 2 . Por outro lado, o daemon ( $c p d_{2}:$ brucutu ) deixou de enviar a mensagem $a_{1}$, pois o valor $r s n$ associado a ela é 2 .

$\mathrm{O}$ daemon sequenciador, por sua vez, não inclui a mensagem $m_{1}$ em sua bag, indicando que ela não será remetida à nova instância.

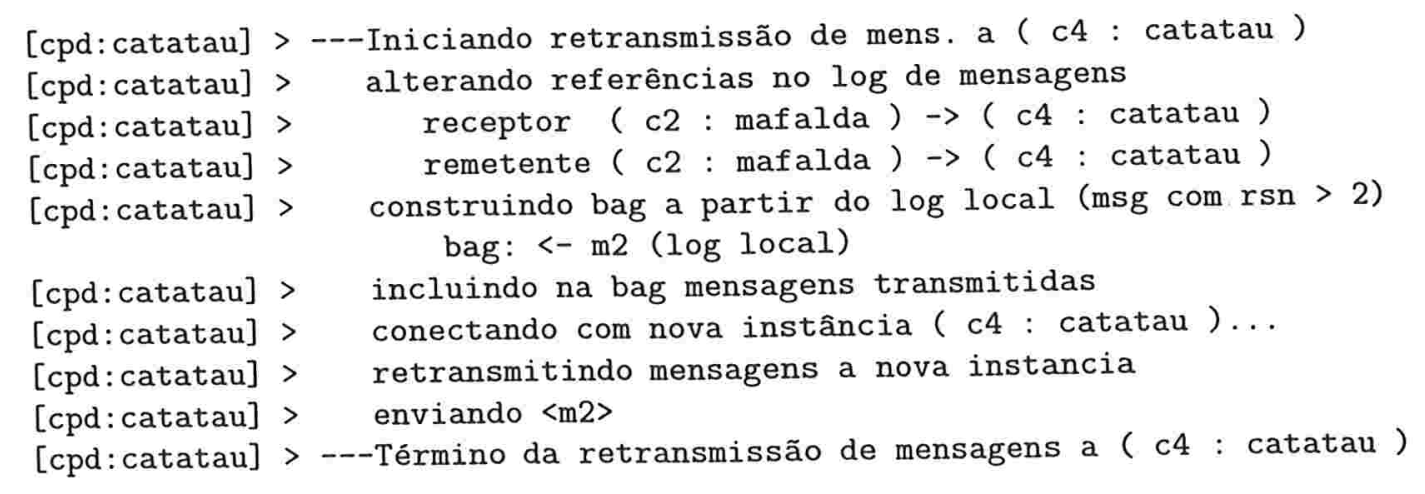

É importante destacar que, ao receber a mensagem $m_{2}$, a nova instância retorna o valor correto de rsn, ou seja, o mesmo valor retornado pela instância faltosa quando a mensagem foi recebida pela primeira vez.

[c4:catatau] $>--$ Chegou $\ll \mathrm{m} 2 \gg$ de $(\mathrm{c} 1$ : catatau ), ssn=2, retornando $\mathrm{rsn}=3$

Além disso, ao enviar as mensagens $x_{1}$ e $x_{2}$, os valores corretos de ssn e rsn são atribuídos às mesmas e uma cópia é enviada ao daemon local. A rejeição das mensagens duplicadas ocorre corretamente, mas não é exibida.

[c4: catatau] > Conectando processo ( c3 : brucutu )...0k, conectado.

[c4:catatau] $>+++$ enviado $<x 1 \gg$ a ( c3: brucutu) sob (ssn=1)

[c4:catatau] $>+++$ enviado copia de $\ll \times 1 \gg$ a ( cpd : catatau) sob (ssn=1, rsn=1)

[c4:catatau] > Conectando processo ( c1 : catatau )...0k, conectado. 


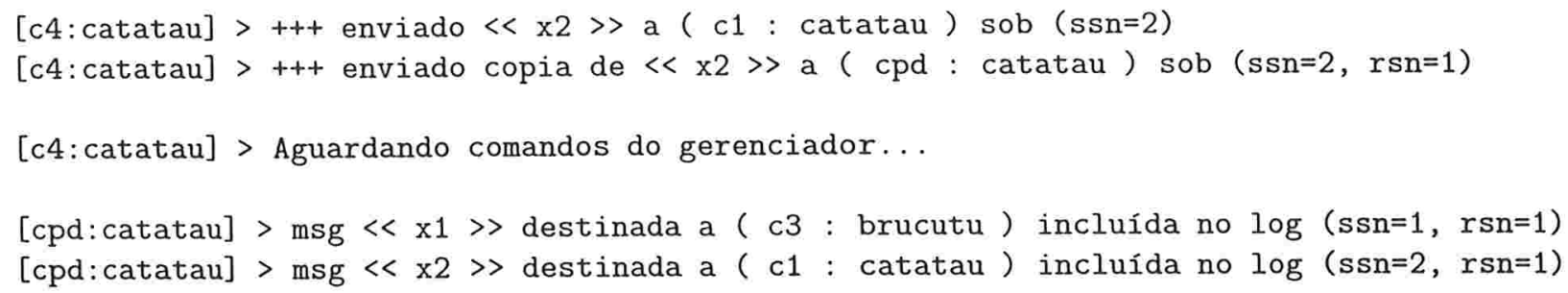

Isto finaliza a reconstrução do estado local da nova instância. As demais características, incluindo a correta execução do sistema após o restabelecimento de estado foram omitidas por serem idênticas ao exemplo anterior.

\subsection{Avaliando mensagens parcialmente armazenadas}

Neste último exemplo, simulamos novamente a falha em ( $c_{2}:$ mafalda ), mas avaliamos o caso onde existam mensagens em seu canal de comunicação, mostrando que a nova instância reprocessará, em um primeiro momento, as mensagens totalmente armazenadas enviadas pelo daemon sequenciador para, finalmente, consumir as mensagens parcialmente armazenadas cujo protocolo de comunicação confiável não foi completado entre o remetente e instância faltosa.

Antes de prosseguir, gostaríamos de explicar que é bastante difícil conseguir uma configuração de mensagens que permita simular a situação em questão. Em parte porque a demora na transmissão das mensagens em nossa rede de computadores leva cerca de 2 segundos, um pouco abaixo dos 3 segundos estabelecidos para detecção de falha. Mesmo usando a versão indeterminística, não seremos felizes em construir uma situação em que exista mensagens no canal de comunicação antes de acionarmos a simulação de falha no gerenciador.

A forma mais conveniente de simular este exemplo é forçar a falha em um processo e posteriormente colocar mensagens em seu canal de comunicação. Talvez isto possa parecer artificial, mas a idéia é mostrar que processos remetentes são capazes de detectar que o valor rsn não retornou e que, portanto, a mensagem parcialmente armazenada (isto é, a mensagem enviada que ainda não teve o protocolo de comunicação confiável completado) deve ser novamente retransmitida à nova instância após seu restabelecimento de estado. Em outras palavras, esta forma artificial é adequada às nossas necessidades, pois não nos importa como as mensagens foram colocadas no canal de comunicação do processo no qual simularemos a falha, mas sim o simples fato de haver mensagens nele.

\subsubsection{Colocando mensagens no canal de comunicação}

Este exemplo será estudado através da configuração de processos ilustrada na figura 6.4 , onde $m_{1}, a_{1}, m_{2}, x_{1}$ e $x_{2}$ constróem a mesma configuração de mensagens estudada até o momento, de forma que omitiremos detalhes sobre a execução dos eventos associàdos.

As mensagens $m c_{1}, m c_{2}, a c_{1}$ e $a c_{2}$ serão colocadas no canal de comunicação do processo 


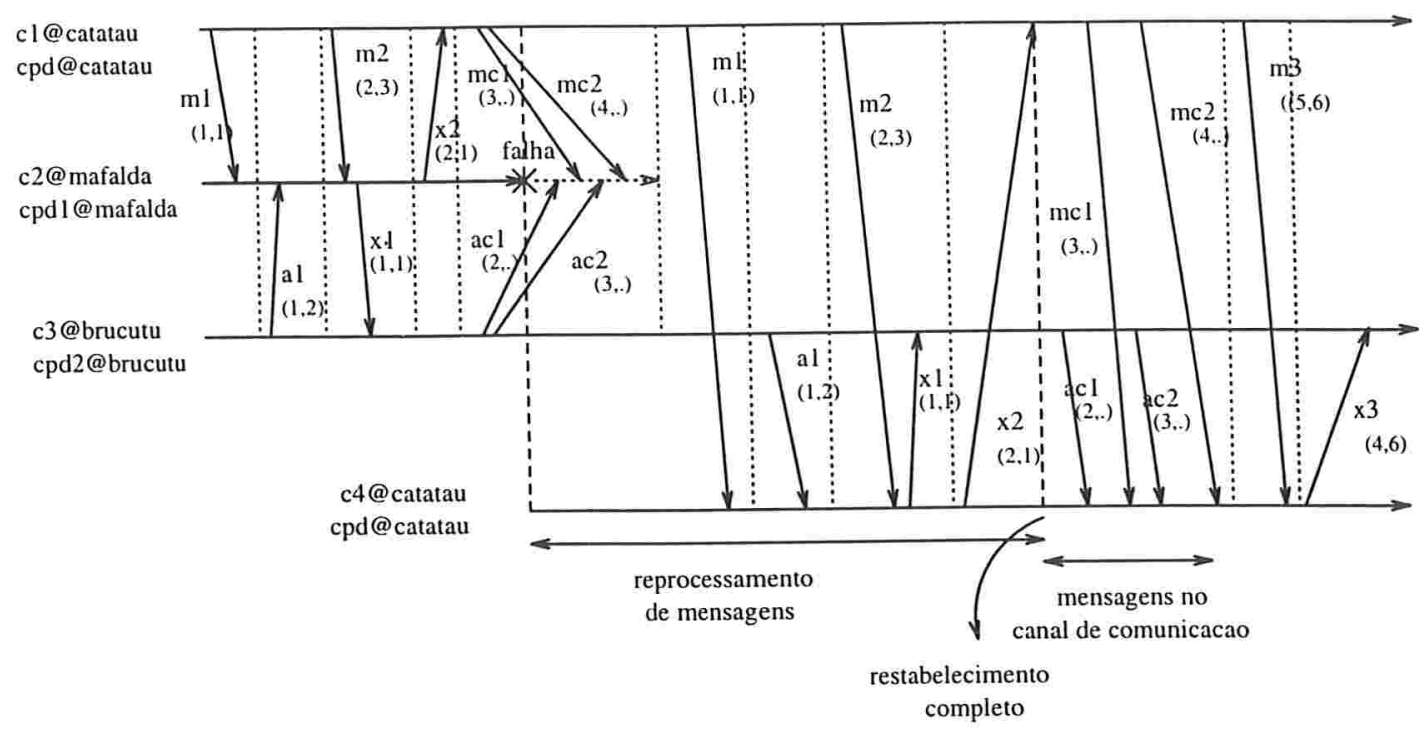

Figura 6.4: Diagrama de eventos com mensagens parcialmente armazenadas

$c_{2}$ imediatamente após a simulação da falha. Para tanto, procederemos da seguinte forma: inicialmente conectamos os processos que enviarão mensagens a $c_{2}$; em seguida, simulamos a falha em $c_{2}$; finalmente usamos uma outra instância do gerenciador para enviá-las ao processo faltoso, causando as seguintes notificações nos processos remetentes:

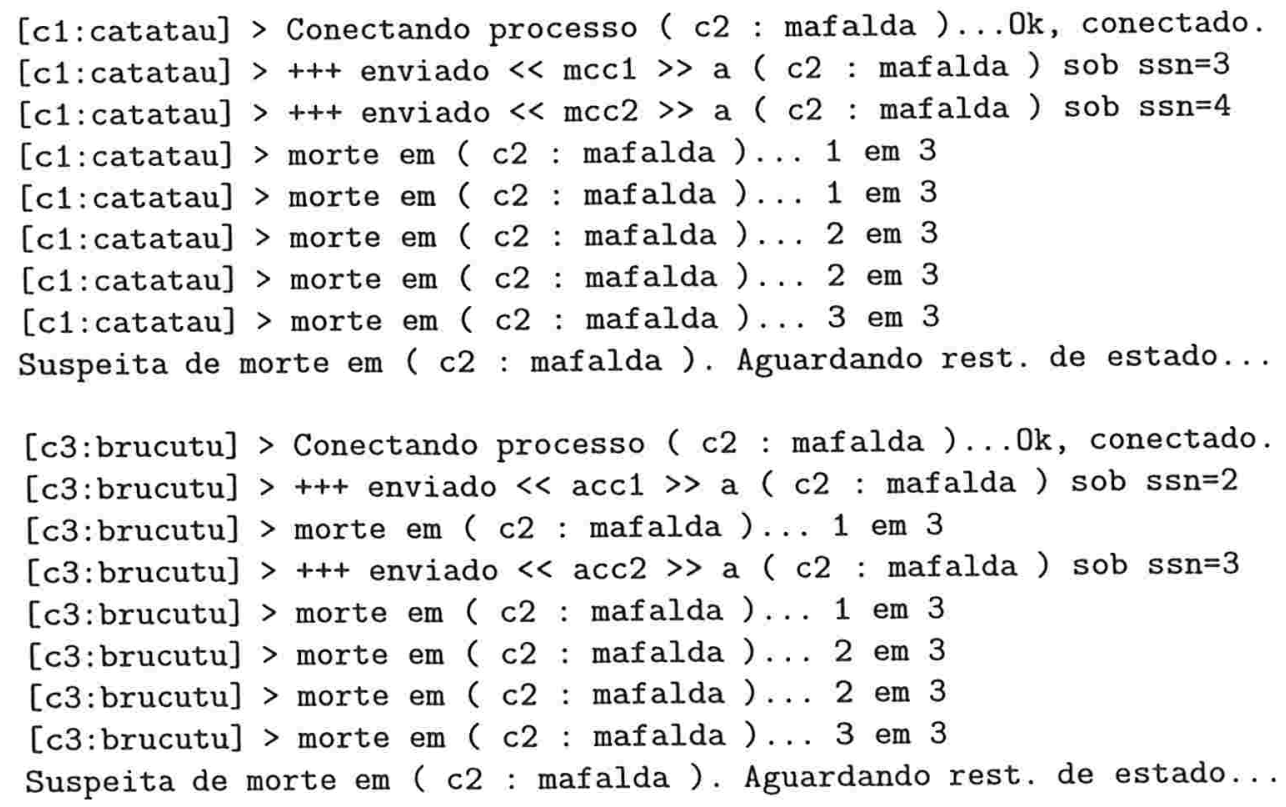

Note que cada remetente envia mensagens parcialmente armazenadas (pois o protocolo de comunicação confiável ainda não foi completado), mas os valores rsn não retornam nos 3 segundos estabelecidos, fazendo-os aguardar o restabelecimento de estado da nova instância. 


\subsubsection{Restabelecimento de estado da nova instância}

Logo após finalizar o consumo das mensagens enviadas pelo daemon sequenciador, o xterm da nova instância exibirá as seguintes notificações:

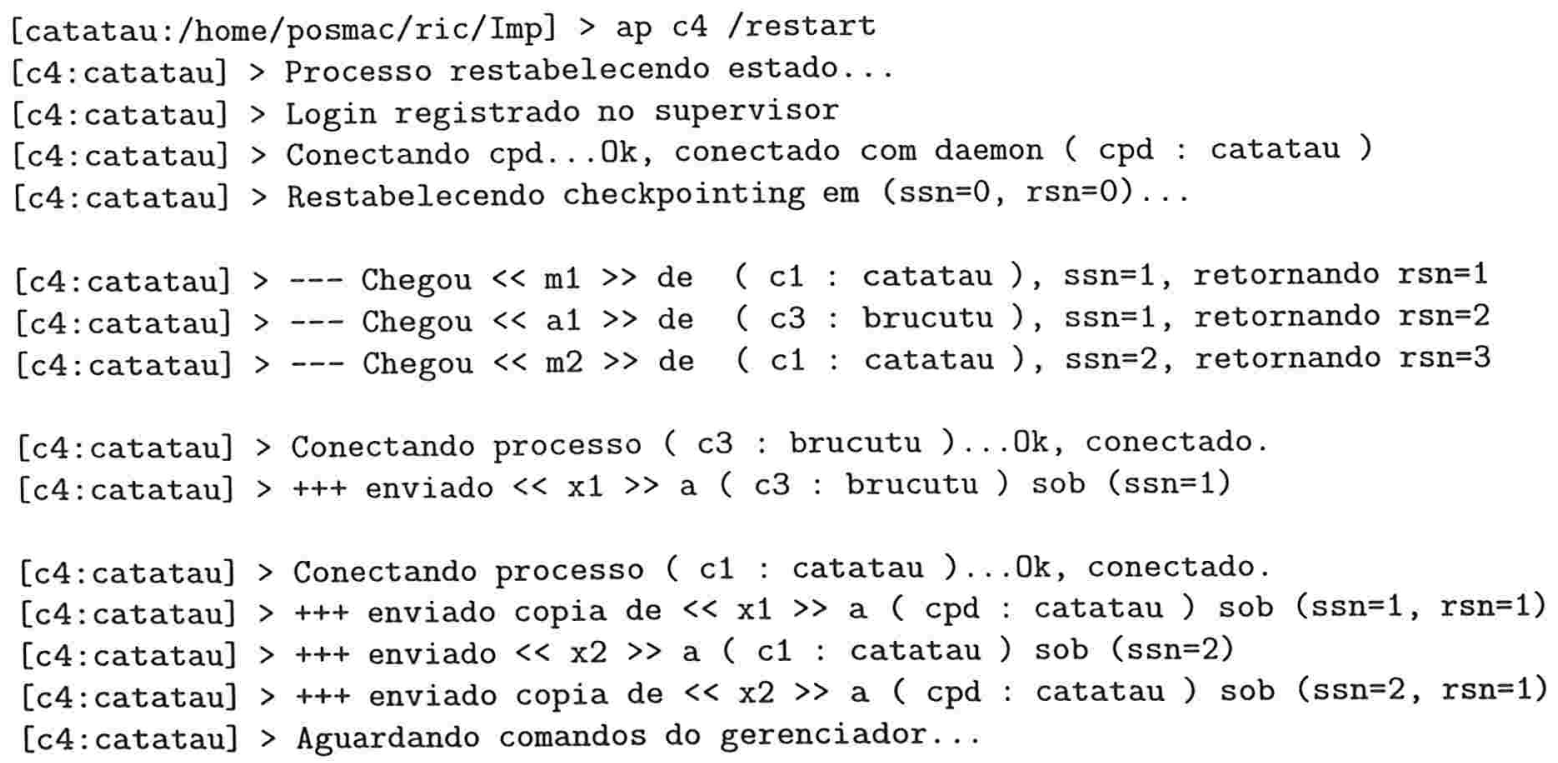

Em seguida, os processos remetentes enviam à nova instância as mensagens parcialmente armazenadas, como podemos observar abaixo.

[c3:brucutu] > Enviando novamente acc1 a ( c4: catatau)

[c3:brucutu] > Enviando novamente acc2 a ( c4 : catatau)

[c3:brucutu] $>+++$ enviado copia de $<$ acc1 $\gg$ a ( cpd2 : brucutu ) sob (ssn=2, rsn=4)

[c3:brucutu] $>+++$ enviado copia de $<$ acc2 $\gg$ a ( cpd2 : brucutu ) sob (ssn=3, rsn=5)

[c1:catatau] > Enviando novamente mcc1 a ( c4 : catatau)

[c1: catatau] > Enviando novamente mcc2 a ( c4 : catatau)

[c1: catatau] > +++ enviado copia de $\ll$ mcc1 $\gg$ a ( cpd : catatau ) sob (ssn=3, rsn=6)

[c1:catatau] $>+++$ enviado copia de $<$ mcc2 $\gg$ a ( cpd : catatau) sob (ssn=4, rsn=7)

e a nova instância informa o usuário sobre as seguintes ações:

[c4:catatau] > --- Chegou $\ll$ acc1 $>$ de ( c3 : brucutu ), ssn=2, retornando rsn=4

[c4:catatau] $>--$ Chegou $<$ acc2 $\gg$ de ( c3 : brucutu ), ssn=3, retornando rsn=5

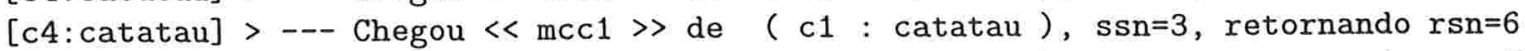

[c4:catatau] >--- Chegou $\ll \mathrm{mcc} 2 \gg$ de ( 1 : catatau ), ssn=4, retornando $\mathrm{rsn}=7$

Neste momento, os logs dos daemons possuem as seguintes mensagens.

[cpd:catatau] >msg $<m 1 ~ \gg$ destinada a ( $\mathrm{c} 2$ : mafalda ) incluída no log ( $\mathrm{ssn}=1, \mathrm{rsn}=1)$ [cpd:catatau] $>\mathrm{msg} \ll \mathrm{m} 2 \gg$ destinada a ( c2 : mafalda) incluída no $\log (\mathrm{ssn}=2, \mathrm{rsn}=3)$ 
[cpd:catatau] $>\operatorname{msg} \ll x 1 \gg$ destinada a ( c3 : brucutu) incluida no log (ssn=1, rsn=1)

[cpd:catatau] $>\mathrm{msg} \ll \mathrm{x} 2 \gg$ destinada a ( $\mathrm{c1}$ : catatau ) incluída no log (ssn=2, rsn=1)

[cpd:catatau] $>\operatorname{msg} \ll \operatorname{mcc1} \gg$ destinada a ( c4 : catatau) incluída no log (ssn=3, rsn=6)

[cpd:catatau] > msg $\ll \operatorname{mcc} 2>$ destinada a ( c4 : catatau) incluída no log (ssn=4, rsn=7)

[cpd2:brucutu] $>\operatorname{msg} \ll$ a1 $\gg$ destinada a ( c2 : mafalda ) incluída no log (ssn=1, rsn=2)

[cpd2:brucutu] $>\mathrm{msg} \ll$ acc1 $\gg$ destinada a ( c4 : catatau ) incluída no log ( $\mathrm{ssn}=2, \mathrm{rsn}=4)$

[cpd2:brucutu] $>\mathrm{msg} \ll$ acc2 $\gg$ destinada a ( c4 : catatau ) incluida no log (ssn=3, rsn=5)

Isto finaliza a construção do estado local da nova instância e mostra que processos remetentes têm condições de detectar falhas, bem como enviar novamente mensagens parcialmente armazenadas pelo novo canal de comunicação.

\subsection{Custos de desempenho do protótipo}

O desempenho do sistema de checkpointing implementado em relação ao método de rastreamento de mensagens é bastante satisfatório durante o período de execução normal do sistema, pois o protocolo de comunicação confiável não degrada significativamente a performance. Segundo nossas medidas, este protocolo requer menos de 1 segundo para ser completado em uma rede com um tráfego de mensagens relativamente alto.

A comunicação entre processos e daemons locais é também satisfatória, pois tanto o envio da cópia da mensagem ao daemon quanto a transmissão de mensagens à nova instância foi estimado em menos de 1 segundo.

Em relação ao tempo estimado para o completo restabelecimento de estado, no entanto, esta versão do protótipo apresenta uma degradação de desempenho significativa em função do timeout utilizado para sincronizar a ação entre os daemons transmissores e o sequenciador. Felizmente, a versão a ser implementada no Sampa prevê uma otimização de pelo menos $50 \%$, devido principalmente a dois fatores: o uso de delimitadores (veja seção 5.3.3) para manipular as mensagens transmitidas ao daemon sequenciador e a definição de duas portas específicas nos daemons, uma para comunicação com o agente local e outra para receber comandos e enviar notificações ao supervisor.

\subsection{Conclusão}

\subsubsection{Vantagens e desvantagens do protocolo}

Nesta seção analisamos as vantagens e desvantagens do método de rastreamento de mensagens implementado, abrangendo aspectos gerais, estruturas de dados e hipóteses necessárias ao protocolo bem como as modificações introduzidas no método originalmente proposto por Johnson e Zwaenepoel. 
O método de rastreamento original estabelecia que os logs de mensagens eram distribuídos proporcionalmente entre todos os processos de aplicação. Entretanto, em nosso protótipo, decidimos centralizá-los em daemons do sistema. As principais vantagens desta mudança são:

- Menor instrumentação do código da aplicação, pois as estruturas de dados e as rotinas para gerenciar a retransmissão de mensagens à nova instância ficam sob controle dos daemons. Isto também torna o sistema mais robusto e permite maior disponibilidade dos processos de aplicação;

- Menor sincronização entre as componentes, pois as fases de transmissão de mensagens ao daemon sequenciador, envio de mensagens à nova instância e consequente reprocessamento de mensagens pela mesma podem acontecer em paralelo com a execução normal do sistema.

Em relação ao método de rastreamento de mensagens implementado, as principais desvantagens são:

- O tráfico de mensagens aumenta por causa das confirmações. No entanto, o protocolo pode ser implementado em qualquer ambiente, não requerendo qualquer tipo de envio de mensagens confiável;

- Existe um overhead de tempo e espaço associado ao armazenamento de informações adicionais (ssn e $r s n)$ nos remetentes. 


\section{Capítulo 7}

\section{Testes com padrões de comunicação}

Neste capítulo estudaremos algumas configurações de processos e aplicações frequentemente encontradas na literatura de sistemas distribuídos, comprovando que nosso protótipo também propicia tolerância a falha nestes casos.

Ao contrário do que fizemos ao analisar os exemplos anteriores, seremos breves na explanação da interação entre as componentes. De uma forma geral, indicaremos os comandos do gerenciador que conduzem a execução do sistema até o instante imediatamente anterior à falha, os submeteremos ao gerenciador e exibiremos o conteúdo dos logs de mensagens dos daemons para ilustrar a configuração de eventos obtida. Finalmente, criaremos a nova instância substituta do processo faltoso e informaremos os resultados exibidos em seu xterm após o restabelecimento de estado.

Para ilustrar as configurações, usaremos a rede de computadores e as mesmas máquinas presentes nos exemplos estudados até o momento, conforme representado na figura 7.1. A idéia é criar cada um dos processos através da seguinte regra de formação: o primeiro processo será chamado $c_{1}$ e executará na máquina catatau; o segundo será criado na máquina mafalda e seu nome será $c_{2}$; o terceiro processo será denominado $c_{3}$ e executará na máquina brucutu, e assim ciclicamente para processos de maior índice, permitindo identificar facilmente onde cada componente do sistema executa. É importante notar que os três daemons serão sempre os mesmos: ( cpd : catatau ), ( $c p d_{1}:$ mafalda ) e ( $c p d_{2}:$ brucutu ), eliminando a necessidade de futuras menções.

Os padrões analisados são:

Mestre-escravo. Uma configuração mestre-escravo é formada por um processo central denominado mestre (master) e vários escravos (slaves). O mestre solicita ordens de serviço (representado por mensagens) a cada um dos escravos, e estes respondem através de mensagens de confirmação.

Estamos interessados em simular falha no mestre após o envio de diversos pedidos de serviços, concluindo que o novo mestre tem condições de enviar novamente os mesmos 


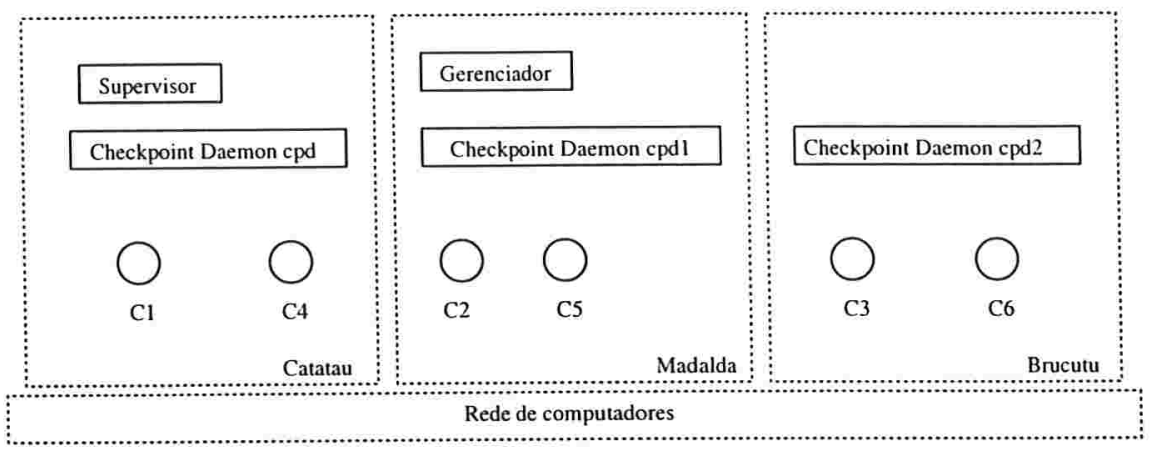

Figura 7.1: Configuração de máquinas para validação do protótipo

pedidos, na mesma ordem originalmente definida pela instância faltosa, bem como receber dos escravos todas as notificações anteriormente destinadas ao mestre faltoso.

Multiplexador FIFO. Um multiplexador FIFO é uma aplicação encarregada de receber mensagens e remetê-las a processos predeterminados. Por exemplo, o caso mais simples é quando o sistema é formado por dois processos, digamos $c_{1}$ e $c_{2}$. Ao receber mensagens de $c_{1}$, o multiplexador deve remetê-las ao processo $c_{2}$. Se tivéssemos mais dois processos em nosso sistema, por exemplo, $c_{3}$ e $c_{4}$, o multiplexador poderia enviar toda mensagem recebida de $c_{3}$ para o processo $c_{4}$.

Simularemos uma falha no multiplexador após receber algumas mensagens do ambiente de processos, sem que ainda as tenha repassado por completo aos respectivos receptores. Com isto, verificaremos que o restabelecimento de estado da nova instância constrói o estado local corretamente, uma vez que o envio das mensagens pendentes é completado com sucesso.

Servidor Intermediário. Um servidor é intermediário quando age como servidor em determinado momento de sua execução, e como cliente em outro instante. Simularemos falha após o servidor intermediário se comportar como servidor e, em seguida, como cliente, ilustrando que a nova instância é capaz de interagir com o ambiente de execução de processos realizando as mesmas comunicações.

Anel unidirecional. Uma estrutura de anel unidirecional é formada por processos conectados em forma de anel. Por exemplo, em um sistema formado por três processos, digamos $c_{1}$, $c_{2}$ e $c_{3}$, poderíamos conectá-los de forma que toda mensagem enviada por $c_{1}$ seja remetida a $c_{2}$, que as repassa a $c_{3}$, que, por sua vez, envia as mensagens recebidas a $c_{1}$.

Simulamos falha em uma das componentes do anel para ilustrar que em um algoritmo distribuído baseado em token, não há perda nem duplicação de token após o restabelecimento de estado.

Anel bidirecional. Em uma estrutura de anel bidirecional existem dois tokens, cada um percorrendo um sentido da estrutura.

Simularemos falha em uma das componentes que detém os dois tokens, concluindo, então, 
que as mesmas características observadas no padrão anterior também são satisfeitas no caso de uma estrutura bidirecional.

Servidor concorrente FIFO. Um servidor concorrente FIFO é uma aplicação que recebe requisições de recursos ou serviços, realiza um processamento interno ou tarefa relativa à requisição e, em seguida, envia notificações aos processos requisitantes. Por exemplo, um servidor de impressão tipicamente recebe diversos pedidos, armazena-os em uma fila e envia notificações aos usuários informando que a impressão ocorrerá assim que o pedido ocupar a primeira posição na fila de impressão. A característica concorrente indica que é possível receber vários pedidos enquanto o servidor realiza o processamento de uma ou mais tarefas.

O servidor implementado permite que o usuário especifique no pedido o tempo de processamento estipulado para a tarefa associada a mensagem recebida. Por exemplo, se o usuário enviar, nesta ordem, as mensagens $m_{3}, m_{1}$ e $m_{5}$ ao servidor, então será consumido 3 segundos para processar a primeira mensagem, 1 segundo para a segunda e 5 segundos para a última mensagem. O atributo FIFO indica que a notificação ao cliente remetente da mensagem $m_{1}$ só será feita após a notificação ao cliente remetente de $m_{3}$, pois servidor recebeu $m_{3}$ antes de $m_{1}$.

Analisaremos o caso de falha em que o servidor recebe várias requisições de serviço, notifica alguns clientes e falha antes de processar todas as tarefas. Com isto, veremos que a nova instância tem condições de receber novamente as mesmas requisições, reprocessá-las e notificar, na mesma ordem, todos os clientes.

Servidor com prioridades. Um servidor com prioridades é uma aplicação que se comporta como o servidor concorrente, mas a regra de notificação aos clientes muda ligeiramente. Ao invés de enviar as notificações seguindo a regra FIFO, usa-se a prioridade definida pela mensagem. Por exemplo, se no padrão anterior a prioridade de $m_{3}$ fosse, digamos $P_{3}$, a prioridade de $m_{1}$ fosse $P_{1}$ e a de $m_{5}$ fosse $P_{5}$ e $P_{3} \leq P_{1} \leq P_{5}$, então obteríamos a mesma regra de envio de notificações mencionada há pouco. Se as prioridades fossem definidas com valores diferentes, então a regra de notificação aos clientes seria outra.

Portanto, a diferença entre o servidor concorrente FIFO e o servidor com prioridades é a função que define a ordem de notificação. Se observarmos com atenção, veremos que esta função não influi no método de rastreamento de mensagens, e por isso decidimos analisar apenas o caso do servidor FIFO.

\subsection{Mestre-escravo}

Para cada simulação estudada neste capítulo exibimos uma ilustração adicional para dar uma visão global do padrão de comunicação analisado. Por exemplo, nesta seção, o mestre do sistema, representado pelo processo ( $c_{1}$ : catatau ), envia as mensagens $m_{1}, m_{2}$ e $m_{3}$ aos escravos que, por sua vez, enviam as notificações $a_{1}, b_{1}$ e $a_{1}$, conforme ilustrado na figura 7.2.

Para descrever a ordem dos eventos, apresentamos em cada padrão um diagrama de eventos conforme representado na figura 7.3 , onde podemos observar que o processo ( $c_{5}:$ mafalda ) será 


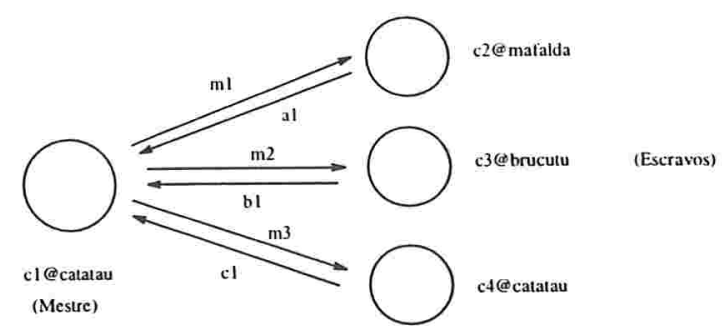

Figura 7.2: Configuração mestre-escravo

o substituto do processo $c_{1}$ no qual simularemos a falha.

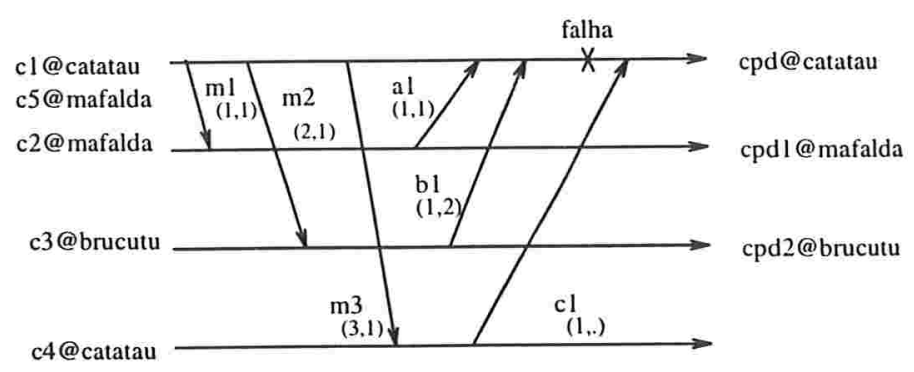

Figura 7.3: Configuração dos eventos

Para simular o padrão mestre-escravo, o usuário deve criar o mestre desta forma:

[catatau:/home/posmac/ric/Imp] > ap c1/simular 1

Os escravos devem ser criados normalmente, sem a necessidade de acrescentar o parâmetro /simular. Em todos os padrões seguiremos esta forma de criação de processos, onde a componente principal é executada com o parâmetro adicional /simular e as demais são instanciadas normalmente, a menos de menção contrária.

Os comandos do gerenciador que geram os eventos representados no diagrama 7.3 são:

p c1 catatau

c c2 mafalda

$\mathrm{s} \mathrm{m} 1$

c c3 brucutu

$\mathrm{s} \mathrm{m} 2$

c c4 catatau

$\mathrm{s}$ m3

Estes comandos completam a rodada de comunicação do mestre $\left(c_{1}:\right.$ catatau $)$. Em seguida, os escravos ( $c_{2}:$ mafalda ) e ( $c_{3}:$ brucutu ) enviam as mensagens $a_{1}$ e $b_{1}$ através dos seguintes comandos. 


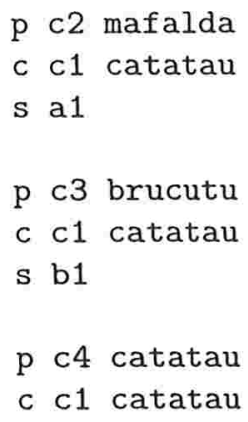

Este último comando conecta o escravo ( $c_{4}$ : catatau ) ao mestre para que, em seguida, simulemos um caso de falha em que haja mensagens no canal de comunicação.

Exibiremos o conteúdo dos logs de mensagens dos daemons para verificar o valor dos contadores de mensagens ssn e rsn de cada processo.

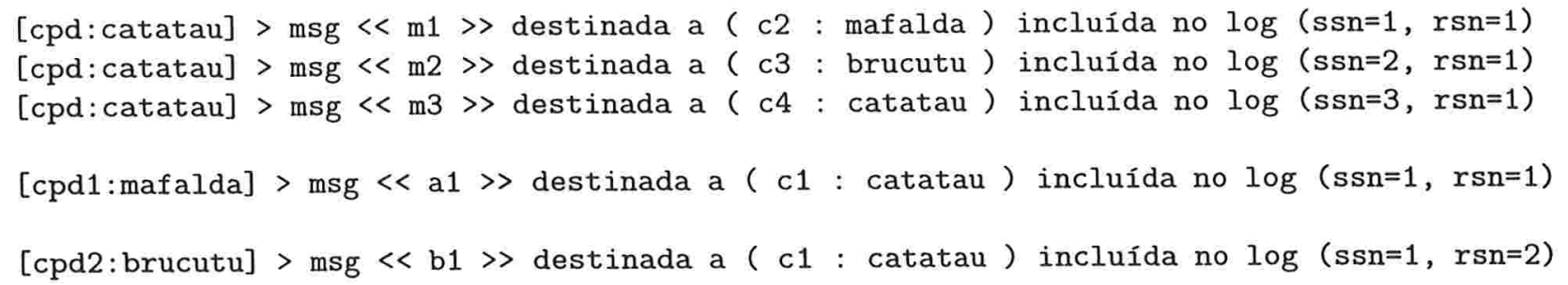

Para simular a falha, o usuário deve solicitar ao gerenciador os seguintes comandos:

p c1 catatau

m c5 mafalda

Para colocar a mensagem $c_{1}$ no canal de comunicação do mestre faltoso, basta fornecer o seguinte comando no xterm da segunda instância do gerenciador.

p c4 catatau

s c1

Durante a fase de restabelecimento de estado, o novo mestre exibe as seguintes notificações:

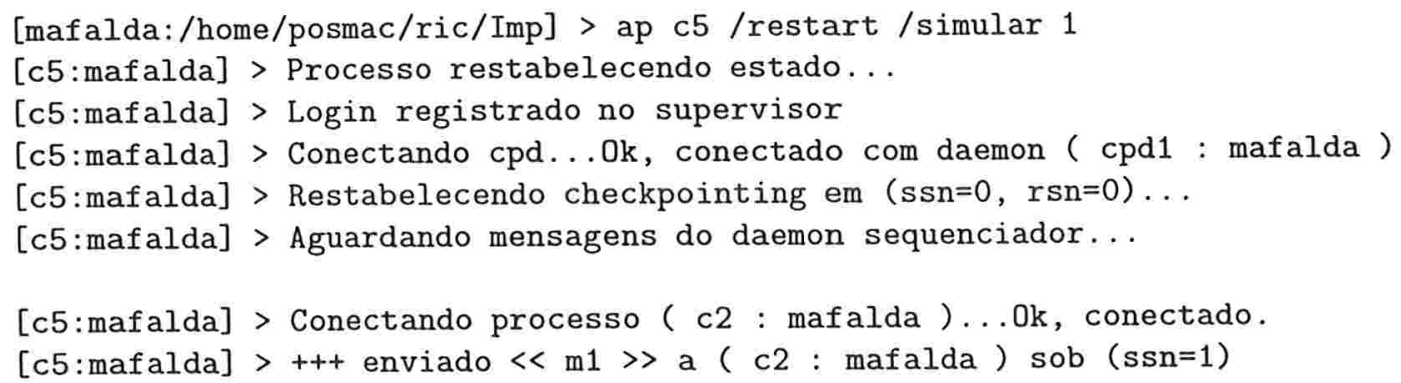




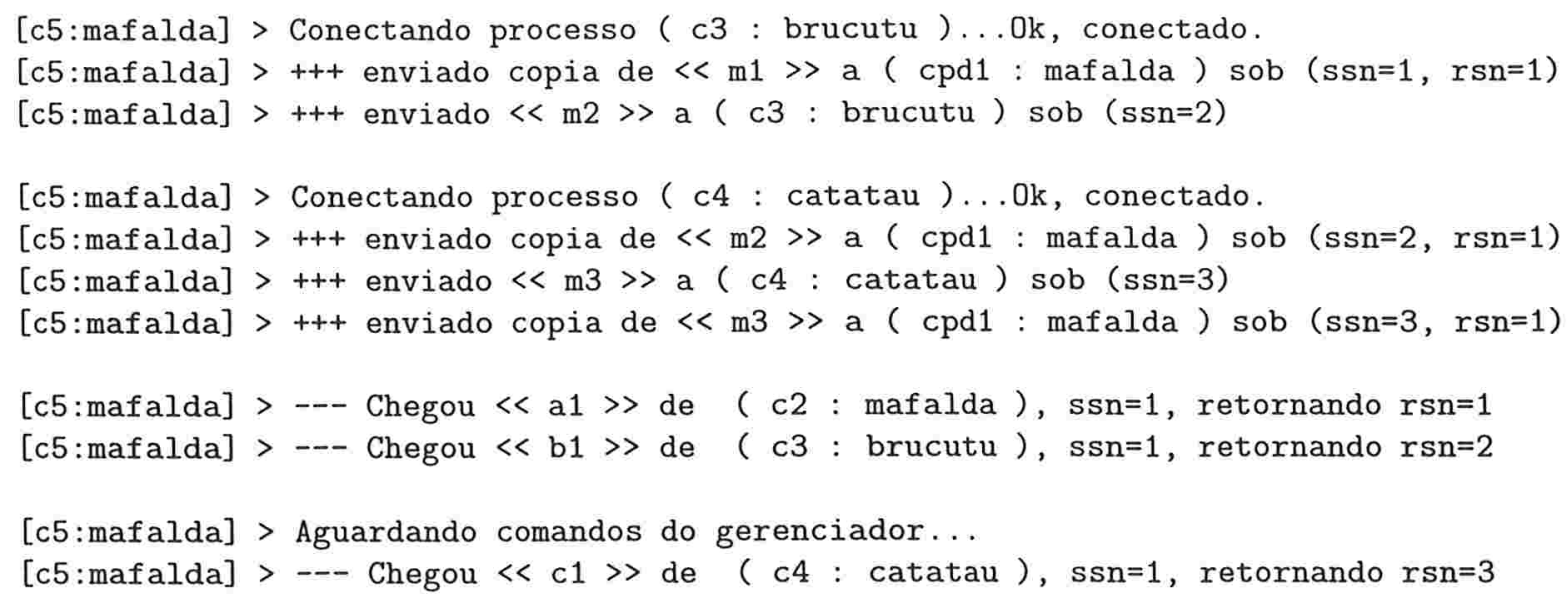

Como podemos observar, o novo mestre enviou novamente as mensagens $m_{1}, m_{2}$ e $m_{3}$ aos respectivos escravos, que as rejeitaram como mensagens duplicadas (veja seção 6.1.3 para mais detalhes). Em seguida, recebeu as mensagens $a_{1}$ e $b_{1}$ enviada pelo daemon $c p d_{1}$ para, finalmente, receber a mensagem $c_{1}$ remetida pelo escravo ( $c_{4}$ : catatau ), finalizando o restabelecimento de estado.

Nas próximas seções exibiremos apenas os fatos ainda não ilustrados em exemplos e situações anteriores e seguiremos a forma de apresentação das interações entre as componentes do protótipo conforme fizemos neste padrão de comunicação inicial.

\subsection{Multiplexador FIFO}

Simularemos o padrão multiplexador FIFO através da configuração de processos ilustrada na figura 7.4.

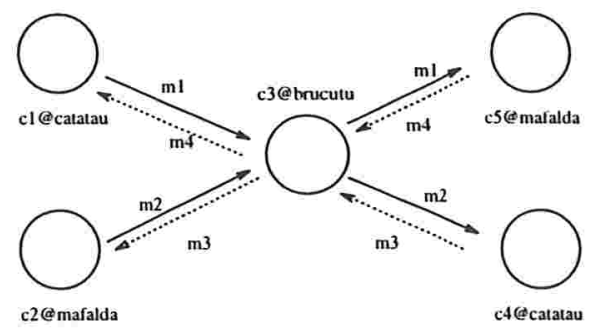

Figura 7.4: Padrão multiplexador FIFO

O multiplexador é representado pelo processo ( $c_{3}:$ brucutu ) e qualquer mensagem enviada por ( $c_{1}$ : catatau ) é remetida a ( $c_{5}$ : brucutu ), e vice-versa, o mesmo acontecendo entre os processos $\left(c_{2}:\right.$ mafalda $)$ e ( $c_{4}:$ mafalda $)$.

Os eventos do sistema serão executados na ordem representada pela figura 7.5. 


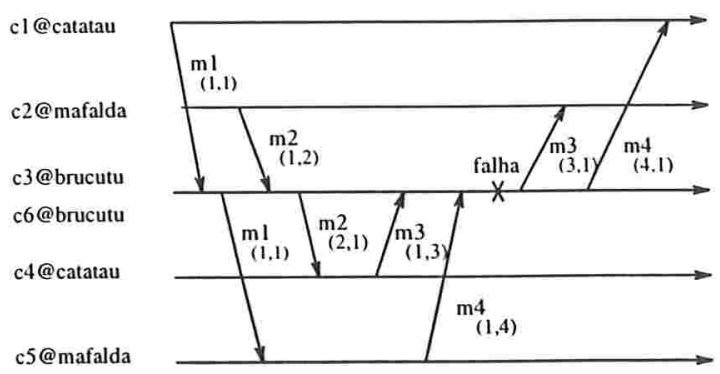

Figura 7.5: Eventos do sistema

Para simular este padrão de comunicação, o usuário deve instanciar o multiplexador desta forma:

[brucutu:/home/posmac/ric/Imp] > ap c3/simular 2

Os comandos do gerenciador responsáveis pelos eventos de envio de mensagens representados na figura 7.5 são:

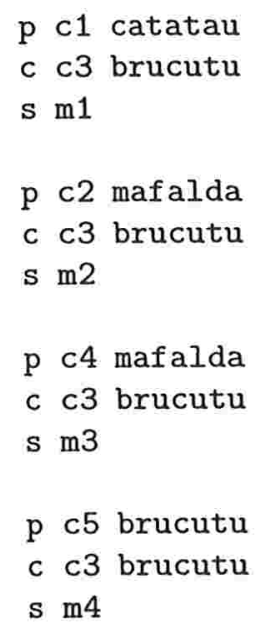

Como podemos observar, apenas o envio das mensagens destinadas ao multiplexador são necessárias, pois o restante do processamento é feito automaticamente. Neste momento, o multiplexador finaliza sua execução e os logs de mensagens dos daemons são formados por:

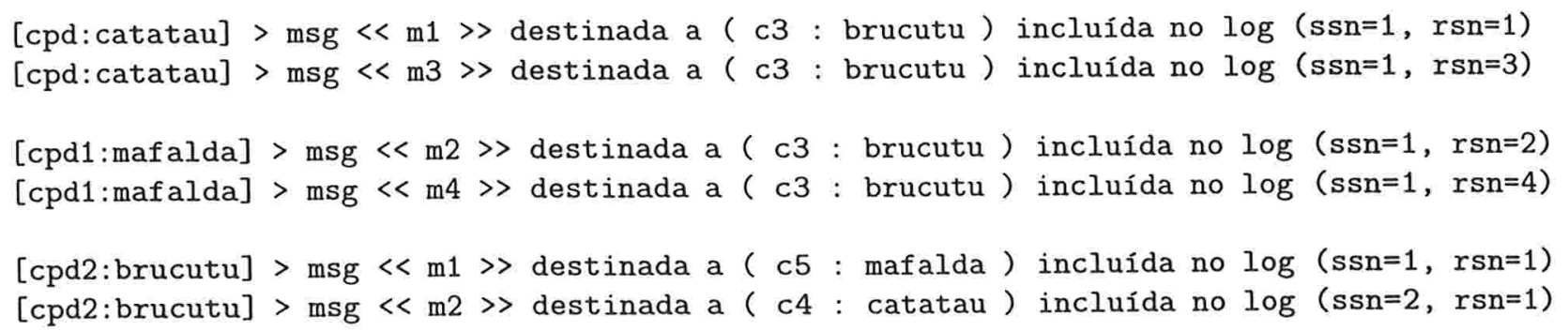


Durante a fase de restabelecimento de estado, a nova instância do multiplexador exibe as seguintes notificações:

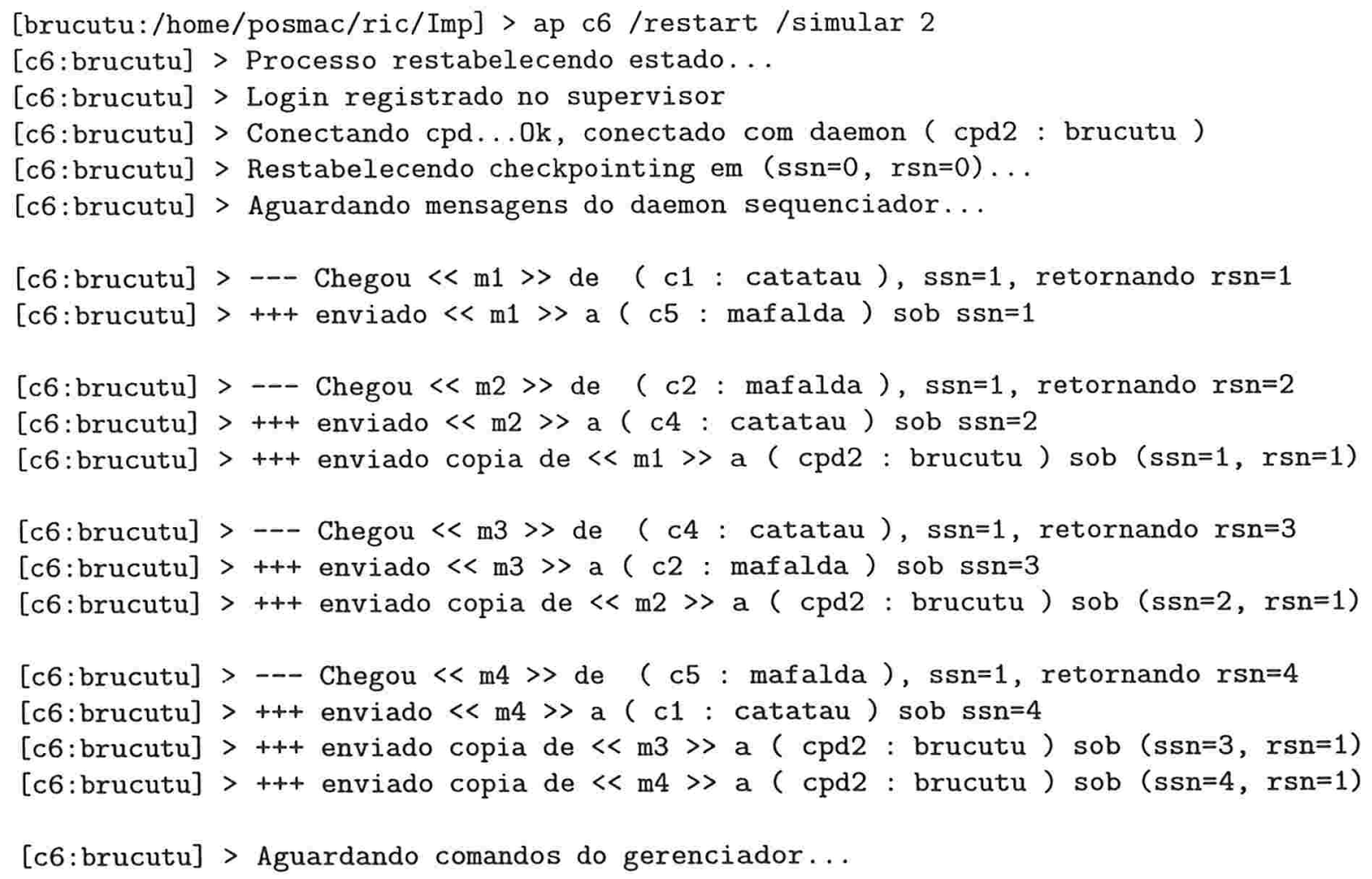

Como podemos observar, o novo multiplexador recebeu do daemon sequenciador as mensagens $m_{1}$ e $m_{2}$ e as entregou aos processos $c_{5}$ e $c_{4}$, respectivamente. Em seguida, as mensagens $m_{3}$ e $m_{4}$ foram entregues ao novo multiplexador, e repassadas aos processos $c_{2}$ e $c_{1}$, de acordo com as informações abaixo.

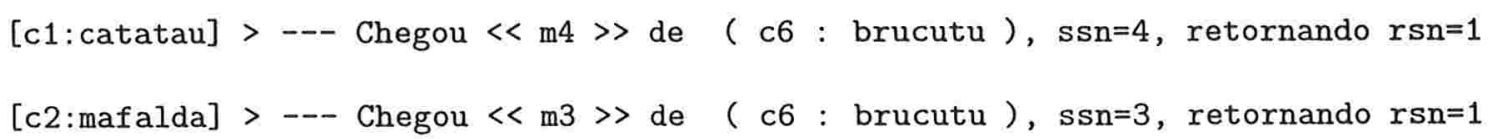

Isto finaliza o restabelecimento de estado, evidenciando que o novo multiplexador construiu seu estado local corretamente, uma vez que os eventos de envio de mensagens pendentes foram completados com sucesso.

\subsection{Servidor Intermediário}

O padrão servidor intermediário é simulado através da configuração de processos exibida na figura 7.6. 


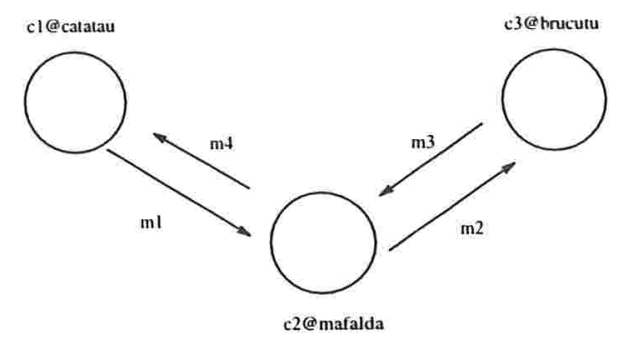

Figura 7.6: Padrão servidor intermediário

O processo ( $c_{2}:$ mafalda $)$ representa o servidor intermediário. Inicialmente, $c_{1}$ envia a mensagem $m_{1}$ ao servidor que, por sua vez, remete automaticamente a mensagem $m_{2}$ a $c_{3}$. Em seguida, $c_{2}$ recebe a mensagem $m_{3}$ e envia $m_{4}$ ao processo $c_{1}$. A falha no servidor ocorre após o envio de $m_{3}$, conforme ilustrado na figura 7.7.

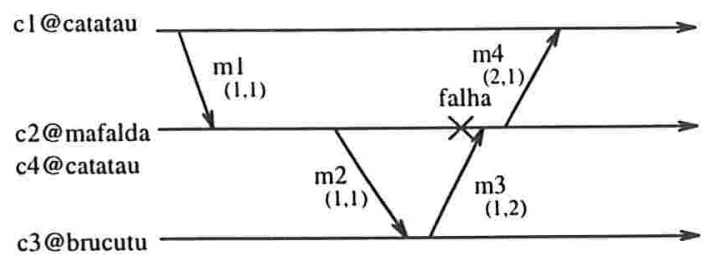

Figura 7.7: Ordem dos eventos

Para simular este padrão de comunicação, o usuário deve instanciar o servidor desta forma: [mafalda:/home/posmac/ric/Imp] > ap c2 /simular 3

Os comandos do gerenciador utilizados neste padrão são:

p c1 catatau

c c2 mafalda

$\mathrm{s} \mathrm{m} 1$

p c3 brucutu

c c2 mafalda

Após a execução, o daemon ( $\mathrm{cpd}$ : catatau ) possui a mensagem $m_{1}$ em seu log e o daemon ( $c p d_{1}$ : mafalda ) contém a mensagem $m_{2}$, sendo que o daemon ( $c p d_{2}:$ brucutu ) não possui mensagens em seu log.

Conforme ilustrado na figura 7.7, o próximo passo é simular a falha no servidor desta forma:

p c2 mafalda

m c4 catatau

Em seguida, o usuário deve colocar a mensagem $m_{3}$ no canal de comunicação do servidor faltoso, usando o seguinte comando. 
$\mathrm{s} \mathrm{m} 3$

Durante o restabelecimento de estado, a nova instância do servidor realiza as seguintes ações:

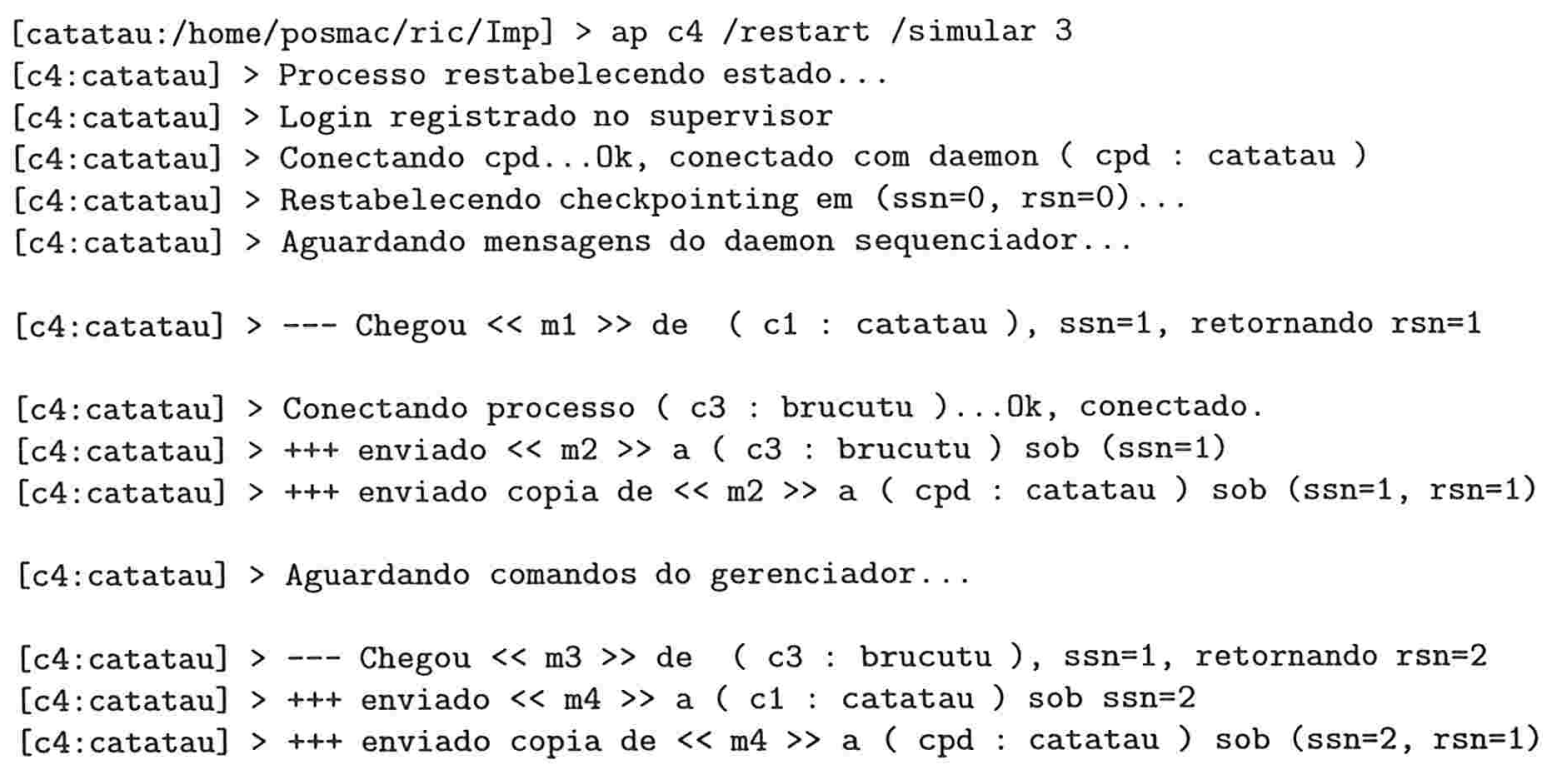

$\mathrm{O}$ novo servidor recebeu a mensagem $m_{1}$ e enviou $m_{2}$ ao processo $c_{3}$, que a rejeita como mensagem duplicada. Em seguida, a mensagem $m_{3}$ é enviada por $c_{3}$ ao novo servidor, que envia $m_{4}$ a $c_{1}$. Estes três últimos fatos podem ser confirmados pelas seguintes notificações exibidas no xterm dos processos $c_{3}$ e $c_{1}$ :

[c3:brucutu] > Mensagem m2 rejeitada como duplicada (retornando $r s n=1$ ).

[c3:brucutu] > Enviando novamente m3 a ( c4 : catatau)

[c3:brucutu] $>+++$ enviado copia de $<$ m3 $\gg$ a ( cpd2 : brucutu ) sob (ssn=1, rsn=2)

[c1:catatau] $>--$ Chegou $\ll m 4 ~>~ d e ~(c 4:$ catatau ), ssn=2, retornando $r s n=1$

Com este pequeno exemplo, verificamos que a nova instância construiu corretamente o estado local, pois a interação do novo servidor com o ambiente ocorreu da mesma forma como se o servidor inicial não houvesse sofrido a falha.

\subsection{Anel unidirecional}

O padrão de comunicação ilustrado na figura 7.8 constitui um anel unidirecional formado por quatro processos conectados no sentido anti-horário. O usuário deve enviar a mensagem $m$ a alguma das componentes, e o os demais envios serão feitos automaticamente.

Se o usuário iniciar o envio da mensagem $m$ pelo processo ( $c_{1}$ : catatau ), obteremos o seguinte diagrama de eventos ilustrado na figura 7.9. 


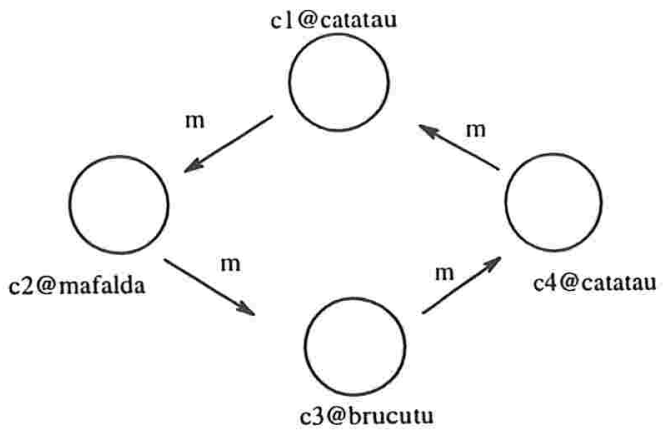

Figura 7.8: Padrão anel unidirecional

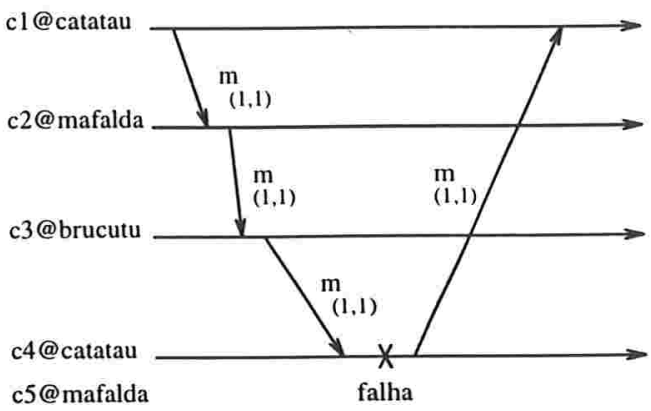

Figura 7.9: Diagrama de eventos

Neste padrão não há uma aplicação central, de forma que todos os processos devem ser criados com o parâmetro /simular 4. Por exemplo, para criar a componente ( $c_{1}$ : catatau ), o usuário deve proceder desta forma:

\section{[catatau:/home/posmac/ric/Imp] > ap c1/simular 4}

Para executar os eventos ilustrados na figura 7.9, o usuário deve solicitar os seguintes comandos ao gerenciador:

p c1 catatau

c c2 mafalda

$\mathrm{s} \mathrm{m}$

Ao receber a mensagem $m$, o processo ( $c_{4}:$ catatau ) simula a falha automaticamente. Após criarmos a nova instância ( $c_{5}:$ mafalda ), ocorrerão as seguintes ações.

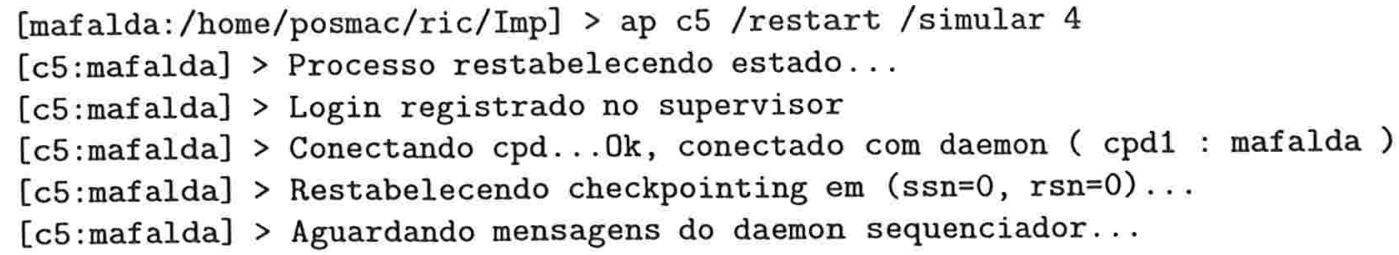


[c5:mafalda] $>--$ Chegou $\ll m ~ \gg$ de ( c3 : brucutu ), ssn=1, retornando rsn=1

[c5:mafalda] $>+++$ enviado $<\mathrm{m} \gg$ a ( $\mathrm{c} 1$ : catatau ) sob ssn=1

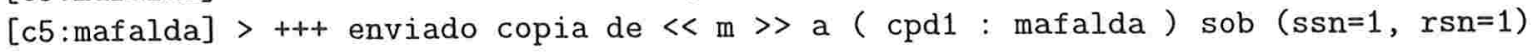

[c5:mafalda] > Aguardando comandos do gerenciador...

Como podemos observar, a nova componente do anel recebeu a mensagem $m$ enviada pelo daemon sequenciador ( $c p d_{1}$ : mafalda ) e a repassou ao processo $c_{1}$, finalizando uma volta completa da mensagem na estrutura.

$[c 1:$ catatau $]>--$ Chegou $\ll m \gg$ de $(c 5:$ mafalda ), ssn=1, retornando $r s n=1$

Este pequeno exemplo permite observar duas características importantes: a primeira indica que não houve perda nem duplicação do token representado pela mensagem $m$; a segunda ilustra a conexão automática entre a nova instância e as componentes anterior e posterior da estrutura de anel.

\subsection{Anel bidirecional}

A estrutura de anel bidirecional é semelhante à estrutura anterior, diferindo apenas pelo número de tokens circulantes: um no sentido horário e outro no anti-horário, conforme representado na figura 7.10 .

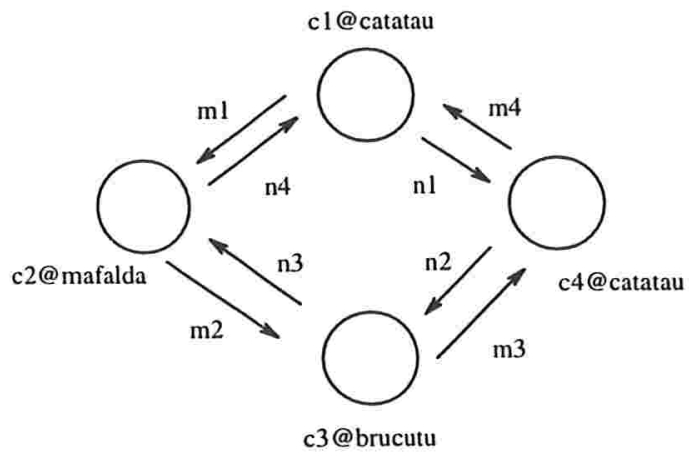

Figura 7.10: Anel bidirecional

A configuração de eventos estudada está representada na figura 7.11, onde o processo $c_{1}$ inicia o envio dos tokens representados pelas mensagens $m_{1}$ e $n_{1}$. Simulamos uma falha na componente ( $c_{2}$ : mafalda ) logo após receber os tokens representados pelas mensagens $m_{1}$ e $n_{3}$. No que segue, mostramos que o restabelecimento de estado da nova instância ( $c_{5}:$ mafalda ) não causa perda nem duplicação dos tokens do sistema.

Após instanciar cada componente do anel (basta adicional/simular 5 na linha de comando), o usuário deve iniciar a circulação dos tokens desta forma: 


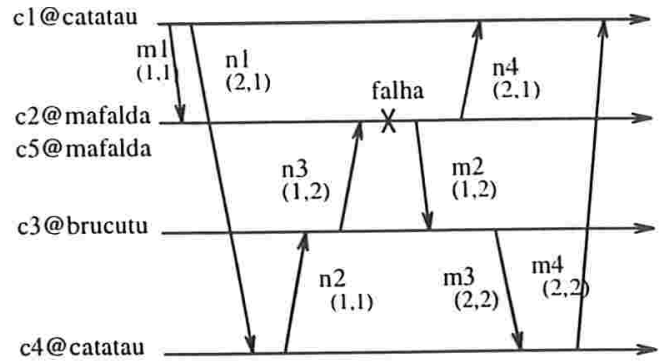

Figura 7.11: Configuração dos eventos

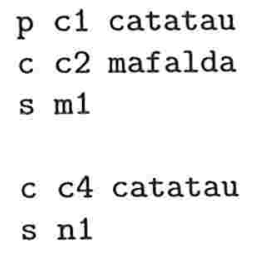

A passagem dos tokens entre os processos é feita automaticamente. Quando $c_{2}$ receber os tokens $m_{1}$ e $n_{3}$, sua execução é finalizada, simulando a falha, e o log de mensagens dos daemons é formado por:

[cpd:catatau] >msg $<\mathrm{m} 1 \gg$ destinada a ( c2 : mafalda) incluída no log ( $\mathrm{ssn}=1, \mathrm{rsn}=1)$ [cpd:catatau] >msg $<\mathrm{n} 1 \gg$ destinada a ( c4 : catatau ) incluída no log (ssn=2, rsn=1) [cpd: catatau] > msg $\ll n 2 \gg$ destinada a ( c3 : brucutu) incluída no log (ssn=1, rsn=1)

[cpd2:brucutu] $>\operatorname{msg} \ll \mathrm{n} 3 \gg$ destinada a ( $\mathrm{c} 2$ : mafalda ) incluída no $\log (\mathrm{ssn}=1, r s n=2)$

O restabelecimento de estado da nova componente $c_{5}$ produz os seguintes resultados:

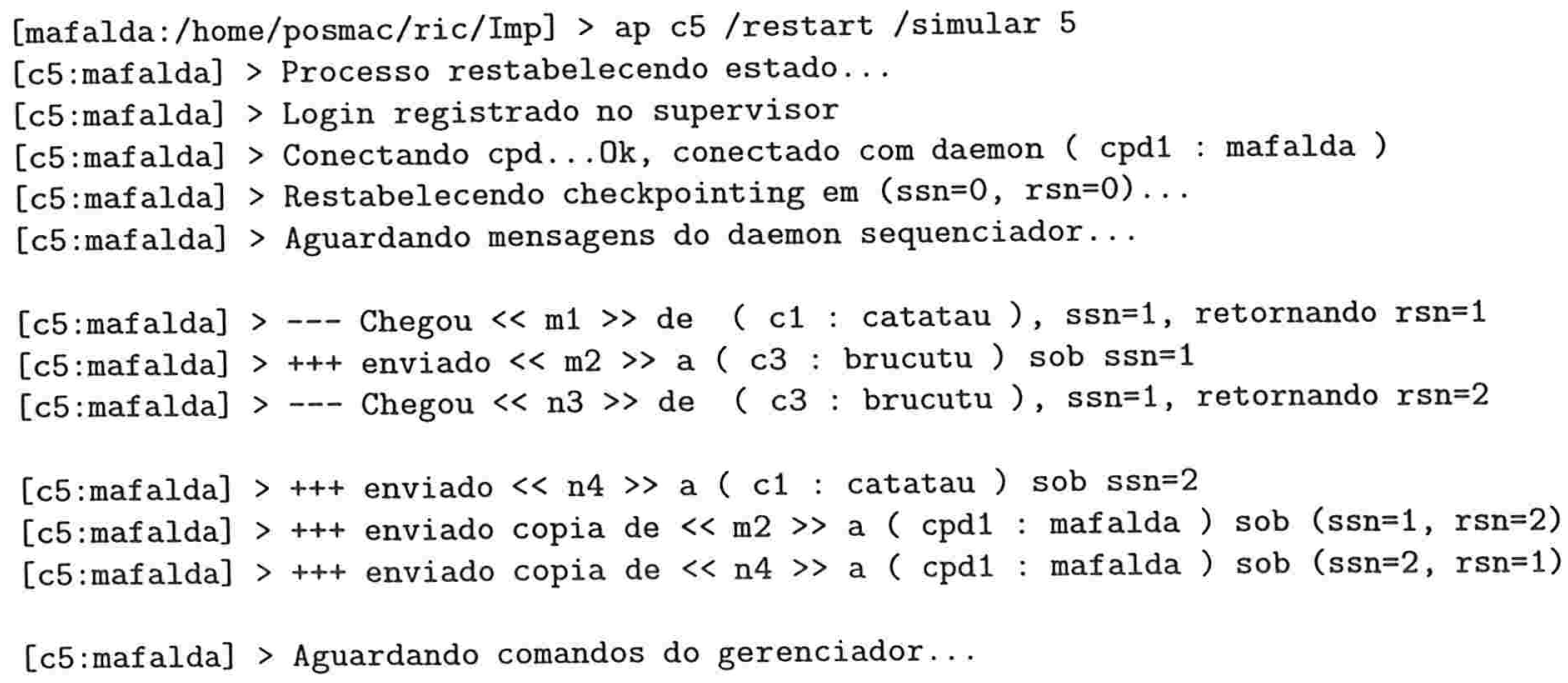

De acordo com as notificações, a nova instância ( $c_{5}$ : mafalda ) recebe do daemon sequenciador os tokens representados pelas mensagens $m_{1}$ e $n_{3}$, com os valores de $s s n$ e $r s n$ esperados, 
repassando-os, em seguida, aos processos seguintes da estrutura, comprovando que não houve perda nem duplicação de tokens.

[c1:catatau] $>--$ Chegou $\ll \mathrm{n} 4 \gg$ de ( 55 : mafalda ), ssn=2, retornando rsn=1

[c1:catatau] $>--$ Chegou $\ll \mathrm{m} 4 \gg$ de $(\mathrm{c} 4$ : catatau ), ssn=2, retornando rsn=2

\subsection{Servidor concorrente FIFO}

Neste último padrão de comunicação, mostramos que processos servidores são tolerantes a falha segundo nossos mecanismos básicos de checkpointing. A figura 7.12 ilustra a configuração analisada.

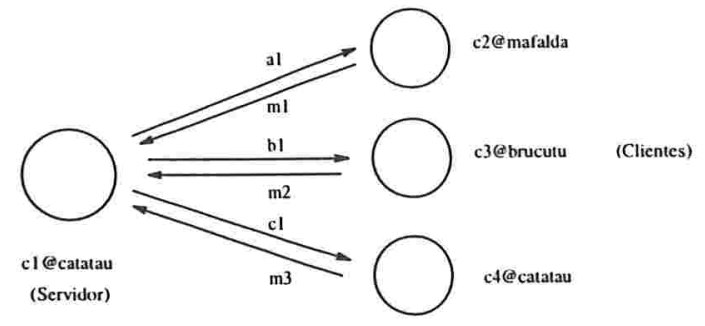

Figura 7.12: Padrão Servidor FIFO

O diagrama de eventos está representado na figura 7.13, onde o servidor ( $c_{1}:$ catatau ) recebe uma mensagem de cada cliente e, na sequência, envia as notificações $a_{1}$ e $b_{1}$ a ( $c_{2}:$ mafalda ) e ( $c_{4}$ : catatau ), sofrendo uma falha antes de notificar o processo ( $c_{3}:$ brucutu).

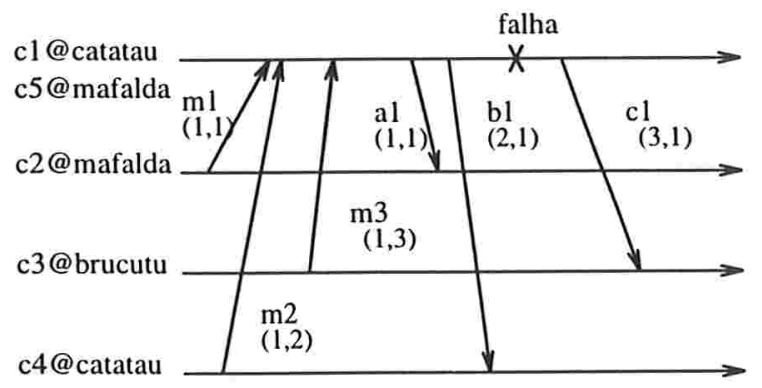

Figura 7.13: Configuração dos eventos no padrão servidor FIFO

Para executar este padrão de comunicação, basta criar o servidor desta forma:

[catatau:/home/posmac/ric/Imp] > ap c1/simular 6

Os comandos a seguir levam o sistema até o momento anterior a simulação da falha.

p c2 mafalda

c c1 catatau 


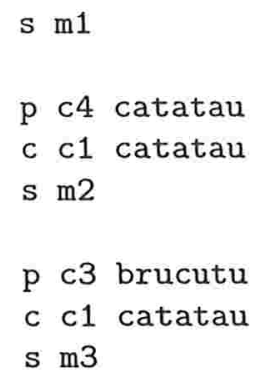

Após executá-los, o conteúdo dos logs de mensagens dos daemons é formado por:

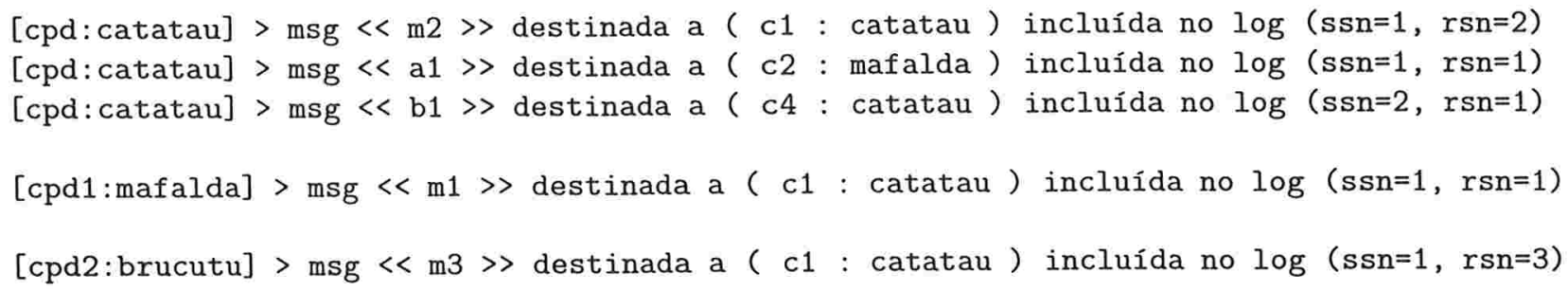

Após criar o novo servidor, o usuário é notificado sobre as seguintes ações:

[mafalda:/home/posmac/ric/Imp] > ap c5/restart/simular 6 [c5:mafalda] > Processo restabelecendo estado...

[c5:mafalda] > Login registrado no supervisor

[c5:mafalda] > Conectando cpd...0k, conectado com daemon ( cpd1 : mafalda)

[c5:mafalda] > Restabelecendo checkpointing em (ssn=0, rsn=0)...

[c5:mafalda] > Aguardando mensagens do daemon sequenciador...

[c5:mafalda] > -- Chegou $\ll \mathrm{m} 1 \gg$ de ( c2 : mafalda ), ssn=1, retornando rsn=1

[c5:mafalda] > Conectando processo ( c2 : mafalda )...0k, conectado.

[c5:mafalda] $>+++$ enviado $\ll$ a1 $\gg$ a ( c2 : mafalda ) sob (ssn=1)

[c5:mafalda] $>--$ Chegou $\ll \mathrm{m} 2 \gg$ de ( $\mathrm{c} 4$ : catatau ), ssn=1, retornando rsn=2

[c5:mafalda] > +++ enviado copia de $<$ a1 $\gg$ a ( cpd1 : mafalda ) sob (ssn=1, rsn=1)

[c5:mafalda] > Conectando processo ( c4 : catatau )...0k, conectado.

[c5:mafalda] $>+++$ enviado $\ll$ b1 $\gg$ a ( c4 : catatau ) sob (ssn=2)

[c5:mafalda] $>--$ Chegou $\ll \mathrm{m} 3 \gg$ de ( c3 : brucutu ), ssn=1, retornando $\mathrm{rsn}=3$

[c5:mafalda] $>+++$ enviado $<$ c1 $\gg$ a ( c3 : brucutu ) sob ssn=3

[c5:mafalda] >+++ enviado copia de $\ll$ b1 $\gg$ a ( cpd1 : mafalda) sob (ssn=2, rsn=1)

[c5:mafalda] >+++ enviado copia de $<\mathrm{c1} \gg$ a ( cpd1 : mafalda) sob (ssn=3, rsn=1)

[c5:mafalda] > Aguardando comandos do gerenciador...

A nova instância reprocessa as mensagens $m_{1}, m_{2}$ e $m_{3}$, notificando os respectivos clientes. Finalmente, $c_{5}$ envia a mensagem $c_{1}$ a ( $c_{3}$ : brucutu ), completando a tarefa pendente deixada 
pelo servidor faltoso. A rejeição das mensagens enviadas em duplicidade e o recebimento de $c_{1}$ podem ser evidenciados a seguir.

[c2:mafalda] > Mensagem a1 rejeitada como duplicada (retornando rsn=1).

[c4: catatau] > Mensagem b1 rejeitada como duplicada (retornando rsn=1).

[c3:brucutu] $>---$ Chegou $\ll c 1 \gg$ de ( c5 : mafalda ), ssn=3, retornando rsn=1

\subsection{Conclusão}

Acreditamos que este pequeno, porém, representativo conjunto de padrões de comunicação analisados são suficientes para mostrar que o protótipo reconstrói de forma correta o estado local da nova instância de um processo faltoso. Gostaríamos de lembrar que estes casos avaliados formam um conjunto bastante reduzido do total de exemplos e simulações estudadas durante a fase de certificação do método de rastreamento de mensagens implementado.

Para finalizar esta seção, ressaltamos que os exemplos apresentados no capítulo anterior em conjunto com os padrões de comunicação propostos nesta seção utilizam toda a potencialidade do protótipo, de forma que todas as característica implementadas foram analisadas em sua íntegra. Uma argumentação mais detalhada sobre a corretude do método de rastreamento de mensagens pode ser encontrada no artigo proposto por Johnson e Zwaenepoel [21]. 


\section{Capítulo 8}

\section{Conclusão}

Nesta seção finalizamos o presente trabalho enfatizando nossa contribuição ao projeto Sampa, descrevendo as experiências acumuladas ao longo destes dois anos de estudo e destacando as dificuldades envolvidas na implementação do protótipo. Posteriormente, mencionaremos possíveis futuros trabalhos visando a integração com o ambiente Sampa.

Uma das ênfases deste estudo consistiu em especificar o método de checkpointing a ser adotado no Sampa, onde a participação do programador é importante na especificação do conteúdo do estado relevante e na determinação dos checkpoints no código da aplicação, responsáveis pelas chamadas às rotinas de checkpointing.

Este método de checkpointing propicia tolerância a falha no nível 2 , significando que a deteç̧ão de falha é automática e o checkpoint local consistente em conjunto com as mensagens rastreadas são suficientes para restabelecer o estado da nova instância de um processo faltoso.

Durante as especificações, estendemos o conjunto de componentes criando daemons responsáveis por gerenciar e armazenar os estados relevantes e os logs provenientes do rastreamento de mensagens, ocasionando, portanto, maior disponibilidade e menor instanciação dos processos tolerantes a falha.

Dentre os aspectos relacionados à programação, a principal dificuldade consistiu em implementar as componentes em ambiente distribuído. A inexistência de memória compartilhada, a diversidade de situações, o entendimento de todos os detalhes relativos à interação entre processos distribuídos e a dependência dos eventos dificultou a estabilidade do sistema e a eliminação completa de deadlocks e erros decorridos de timeouts. Embora a linguagem de programação Concert/C possua uma série de recursos e facilidades, a falta de um ambiente integrado de desenvolvimento e de ferramentas para depuração de processos dificultou ainda mais a conclusão do trabalho.

A implementação do mecanismo de rastreamento de mensagens foi bastante complexa, embora a proposta apresentada por Johnson e Zwaenepoel parecesse, inicialmente, simples. Os principais obstáculos consistiram em gerenciar todas as informações e estruturas de dados necessárias ao método e ao protocolo de comunicação confiável, manipular corretamente as mensagens con- 
tidas nos logs dos daemons durante o restabelecimento de estado e sincronizar as ações entre as componentes no reprocessamento de mensagens à nova instância.

O gerenciamento dos estados relevantes e dos logs de mensagens por daemons do sistema, ao invés de deixá-los sob o controle dos processos de aplicação, também trouxe uma série de complicações, tais como, coordenar todas as componentes distribuídas para que as mensagens totalmente armazenadas fossem consumidas pela nova instância antes das parcialmente armazenadas e permitir a comunicação dos daemons durante o restabelecimento de estado sem que ficassem indisponíveis aos processos de aplicação.

Visando a integração com o ambiente Sampa, destacamos os seguintes futuros trabalhos:

Uma tarefa inicial consiste em estender nosso supervisor para conter todas as características definidas no Sampa, tais como, manter em sua base de dados uma referência completa sobre as componentes cadastradas, e inserir referências sobre quais processos utilizam as facilidades de checkpointing. Com relação a esta última característica, é importante observar que o rastreamento de mensagens deve envolver todos os processos de aplicação cadastrados, e não apenas aqueles que utilizam os mecanismos básicos de checkpointing, pois o restabelecimento de estado requer a participação, no protocolo de comunicação confiável, de todos os processos que efetuaram comunicação com a instância faltosa.

O gerenciador é uma componente adicional utilizada para simular falha em processos. No entanto, está sendo implementado no Sampa um mecanismo de monitoramento que permitirá aos agentes do sistema detectá-las e notificá-las ao supervisor para que, em conjunto com os daemons, ocorra o restabelecimento de estado da nova instância. Este mecanismo de monitoramento deve ser integrado ao protótipo.

Quando um processo de aplicação suspeita da falha em outro processo, é exibida uma notificação ao usuário. No entanto, o supervisor é o responsável por tratar este tipo de informação, e deve ser previsto uma opção para inibi-la, evitando sobrecarga com diversas notificações relativas a uma mesma suspeita de falha. Outra característica a incorporar é permitir que os processos de aplicação disponibilizem uma porta de comunicação adicional para que o supervisor atualize, de forma remota, as referências a portas inválidas. Atualmente, o gerenciador solicita a atualização e os processos consultam o supervisor para obter as novas referências.

Com relação aos checkpoint daemons, é necessário implementar a comunicação entre a nova instância, o daemon sequenciador e os transmissores usando delimitadores ao invés de timeouts. Isto possibilita maior controle na transmissão de mensagens durante o restabelecimento de estado e, consequentemente, maior confiabilidade do sistema. Esta alteração é simples de ser programada, bastando apenas alterar a rotina que insere na bag as mensagens enviadas pelos daemons transmissores, permitindo manipular os delimitadores de início e fim de transmissão.

O mecanismo de rastreamento deve ser eventualmente expandido para incluir mensagens inter-aplicações, pois em nosso protótipo demos ênfase as mensagens trocadas entre diversos processos de uma mesma aplicação.

Outra adaptação diz respeito a inclusão dinâmica de novos integrantes em um grupo de processos. Para tanto é importante permitir a transferência de estados relevantes entre proces- 
sos, evitando que o novo integrante construa obrigatoriamente seu estado relevante a partir do último checkpointing em disco efetuado por um membro do grupo. É provável que isto acarrete adaptações no protocolo de rastreamento de mensagens para que todas as mensagens destinadas aos membros do grupo sejam gravadas, e posteriormente reprocessadas pelo novo membro, permitindo que seu estado local reflita o estado dos membros do grupo de processos.

Com relação ao serviço de checkpointing, é necessário torná-lo tolerante a falha. Isto pode ser feito, por exemplo, replicando o estado de cada daemon do sistema em outros daemons, ou fazendo com que, periodicamente, os logs de mensagens sejam armazenados em disco. Neste último caso, os daemons teriam que implementar exatamente o protocolo definido por Johnson e Zwaenepoel para as comunicações efetuadas entre sí.

Para finalizar, um estudo interessante seria verificar se é razoável relaxar a condição de reprocessamento de mensagens pela nova instância. Atualmente, o consumo das mensagens totalmente armazenadas é feito na mesma ordem em que foram processadas pela instância faltosa. No entanto, talvez seja suficiente reprocessá-las usando apenas a ordem causal. Isto poderia simplificar a fase de restabelecimento de estado e, provavelmente, o protocolo de comunicação confiável. No entanto, é importante notar que isto não garante a obtenção do mesmo estado local original, embora o estado obtido seria correto no sentido de poder ter ocorrido. 


\section{Referências Bibliográficas}

[1] Allan Bricker, Michael Litzkow and Miron Liviny. "CONDOR Technical Summary." University of Wisconsin, Madison, 1996.

[2] J. S. Auerbach et. al. "Concert/C Tutorial and User's Guide. An Introduction to a Language for Distributed C Programming". IBM Corporation, 1993,1994.

[3] G. Barigazzi and L. Strigini. "Aplication-Transparent Setting of recovery Points". Digest FTCS-13, Milano, Italy, pp 48-55, Jun 1983.

[4] D. Bitton and J. Gray. "Disk shadowing". In Proc. of the 14th Conf. on Very Large Data Bases, p 222-229, July 1991.

[5] A. Borg, J. Baumbach and S. Glazer. "A Message System Supporting Fault-Tolerance". In Proc. 9th Symp. on Operating Systems Principles, Oct. 1983, pp.90-99

[6] Gilbert Cabillic, Gilles Muller, Isabelle Puaut. "The Performance of Consistent Checkpointing in Distributed Shared Memory Systems". IRISA, Campus de beaulieu, 35042 Rennes Cédex FRANCE.

[7] K.M. Chendy and L. Lamport. "Distributed Snapshots: Determining Global States od Distributed Systems". ACM Trans. on Computer Systems, 3(1), Feb. 1985, pp. 63-75

[8] M. Dal Cin, A. Grygier, H. Hessenauer, U. Hildebrand, J. Honig, W. Hohl, E. Michel and A. Pataricza. "Fault-Tolerance in Distributed Shared Memory Multiprocessors". To appear in: Springer Lecture Notes on Computer Science, 1993.

[9] E. N. Elnozahy, W. Zawaenepoel and Willy Zwaenepoel. "The performance of Consistent Checkpointing". Department of Computer Science, Rice University, Houston, Texas 772511892

[10] E. N. Elnozahy and W. Zawaenepoel. "Manetho: Transparent Rollback-Recovery with Low Overhead, Limited Rollback and Fast Output Commit". IEEE Trans. on Computers, 41(5), pp.526-531, May 1992.

[11] E. N. Elnozahy and W. Zawaenepoel. "Implementation and Performance of RolllbackRecovery in Manetho". to be published 
[12] M. Endler and A. Souza. "Supporting Distributed Application Management in Sampa". Technical report RT-MAC-9516, Universidade de São Paulo, Nov. 1995.

[13] Erik Seligman and Adam Berguelin. "High Level Fault Tolerance in Distributed Programs". Technical report CMU-CS-94-223, Carnegie Mellon University, Dec. 1994

[14] Erik Seligman, Adam Berguelin, et. al.. "Dome: Parallel programming in a heterogeneous multi-user environment". Technical paper submission for Supercomputing '95, Carnegie Mellon University, April 1, 1995

[15] Fredrich Douglis, John Oustehout. "Process Migration in the Sprite Operating System". 7th International Conference on Distributed Computing Systems, September 1987

[16] F. Di Giandomenico and L. Strigini. "Implementation and Extensions of the Conversation Concept". Proc. of the 5th Int. GI/ITG/GMA Conf. on Fault-tolerant Computing Systems, Nurnberg, Germany, 1991

[17] Y. Huang and C. Kintala. "Software fault tolerance in the application layer". In Software Fault Tolerance, Chapter 10, Editor Michael Lyu, John Wiley and Sons Ltd., March 1995

[18] Y. Huang, P. Jalote, C. Kintala. "Two Techiniques for Transient Software Error Recovery". Lecture Notes in Computer Science, Vol. 774 pp. 159-170, Dec. 1993

[19] James S. Plank, Micah Beck, Gerry Kingsley. "Libckpt: Transparent Checkpointing Under Unix". USENIX Winter 1995 Technical Conference, pp 16-20, Jan. 1995

[20] John Bloomer. "Power Programming with RPC". O'Relly \& Associates, 1992

[21] D. B. Johnson and W. Zwaenepoel. "Sender-Based Message Logging". Digest FTCS-17, Pittisburgh, PA, pp. 14-19, Jul. 1987.

[22] B. W. Johnson. "Design and analysis of fault-tolerant digital systems". Addison-Wesley Publishing Company Inc., 1989

[23] T. Joseph and K. Birman. "Low Cost Management of Replicated Data in Fault-tolerance Distributed Systems". ACM Trans. Comput. Sys., vol. 4, no. 1, pp. 54-70, Feb, 1986

[24] K. H. Kim and A. Kavianpour. "A Distributed Recovery Block Approuch to Fault-Tolerant Execution of Application Tasks in Hypercubes". IEEE Trans. on Parallel and Distributed Systems, 4(1):104-111, Jan. 1993.

[25] R. Koo and S. Toueg. "Checkpointing and Rollback-Recovery for Distributed Systems". IEEE Trans. on Software Engeneering, SE-13(1), Jan. 1987, pp 23-31

[26] P.A. Lee and T. Anderson. "Fault-Tolerance: Principles and Practice". Series: Dependable Computing and Fault-Tolerant Systems, Vol 3, Springer-Verlay, Wien, NY, 90

[27] K. Li and P. Hudak. "Memory Coherence in Shared Virtual Memory Systems". ACM Transactions on Computer Systems, 7(4)321-357, November 1989 
[28] A. Nangia and D. Finker. "Transaction-based Fault-Tolerance Computing in Distributed Systems". In proceedings of 1992 IEEE workshop on fault-tolerante parellel and distributed systems, pages 92-97, July 1992.

[29] Pankaj Jalote. "Fault Tolerance in Distributed Systems". Prentice Hall, 1994

[30] M.L. Powell and D.L. Presotto. "PUBLISHING: A reliable Broadcast Communication Mechanism". Proc. of 9th ACM Symp. on Operating Systems Principles, Oct. 1983.

[31] D. K. Pradhan. "Fault-Tolerance Computing: theory and techniques". Vols 1 e 2, PrenticeHall, 1986

[32] Sape Mullender. "Distributed Systems". Addison Wesley, 1993

[33] M. Satyanarayanan. "Coda: A Highly Avaliable File System for a Distributed Worstation Environment". IEEE Transactions on Computer, C-39:447-459 1990.

[34] J. H. Saltzer, D. P. Reed and D. D. Clark. "End-to-end arguments in System Design". ACM Transactions on Computer Systems, 2(4):277-288, 1984.

[35] J. Shirley, W. Hu and D. Magin. "Guide to Writing DCE Applications". O'Relly \& Associates Inc., 1994

[36] D. P. Siewiorek and R. S. Swarz. "Reliable computer Systems Design and Implementation". Digital Press, Chapter 7, 1992.

[37] L.M. Silva and J.G. Silva. "Global Checkpointing for Distributed Programs". Proc. of 11th Symp. on Reliable Distributed Systems, Houston, pp 155-162 Oct 1992.

[38] R. E. Strom and S. A. Yemini. "Optimistic Recovery: an Asynchronous Approach to FaultTolerance in Distributed Systems". Proc. of 14th Int Fault-tolerant Computing Systems, Florida, pp 374-379, 1984.

[39] Y. Tamir and C. H. Sequin. "Error Recovery in Multicomputers Using Global Checkpoints". 13th Int. Congress on Parallel Processing, Bellaire, MI, pp. 32-41, Aug. 1984.

[40] M. M. Theimer , K. A. Lantz and D. R. Cheriton. "Preemptable remote executing facilities for the V-System". Proc. of the 10th Symp. on Operating Systems Principles, Orcas Island, W.A., pp. 2-12, 1985. In ACM Operating Systems Review 19(5).

[41] Yi-Min Wang, Y. Huang, K. Vo, P. Chung, C. Kintala. "Checkpointing and Its Applications". In Proc. IEEE Fault-Tolerant Computing Symp. (FTCS-25), pp 22-31, June 1995.

[42] E. Zayas. "Attaching the Process Migration Bottleneck". In Proc. of the 11th Symp. on Operating Systems Principles, Austin, Tx, pp. 13-24, 1987. In ACM Operating Systems Review 21(5). 